Ayer mineros, hoy ecoguías y concesionarios Tensiones en torno a la conservación ambiental, el uso de la tierra y el trabajo en Guasca, Cundinamarca

Felipe Rojas Arias

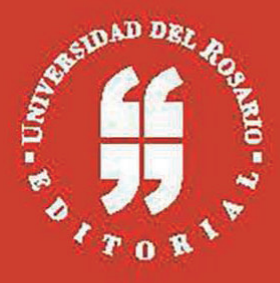

Opera Prima

Escuela de Ciencias Humanas 

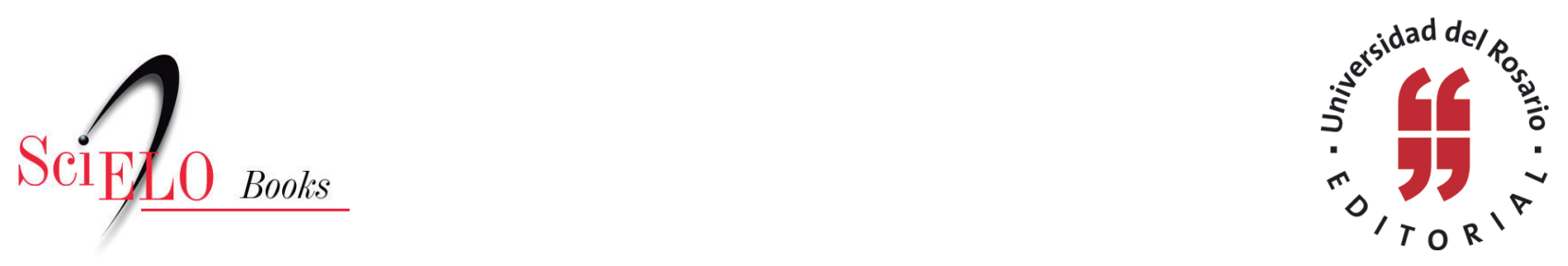

\title{
Ayer mineros, hoy ecoguías y concessionários tensiones en torno a la conservación ambiental, el uso de la tierra y el trabajo en Guasca, Cundinamarca
}

\author{
Felipe Rojas Arias
}

\section{SciELO Books / SciELO Livros / SciELO Libros}

ROJAS ARIAS, F. Ayer mineros, hoy ecoguías y concesionarios: tensiones en torno a la conservación ambiental, el uso de la tierra y el trabajo en Guasca, Cundinamarca [online]. Bogotá: Editorial Universidad del Rosario, 2015, 208 p. Opera prima collection. ISBN: 978-958-738-589-2. https://doi.org/10.7476/9789587385892.

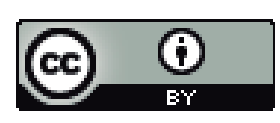

All the contents of this work, except where otherwise noted, is licensed under a Creative Commons Attribution 4.0 International license.

Todo o conteúdo deste trabalho, exceto quando houver ressalva, é publicado sob a licença Creative Commons Atribição 4.0.

Todo el contenido de esta obra, excepto donde se indique lo contrario, está bajo licencia de la licencia Creative Commons Reconocimento 4.0. 


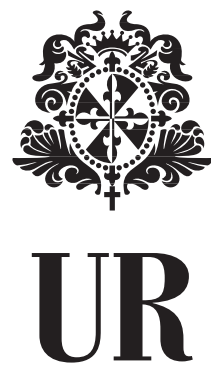





\section{AYER MINEROS, HOY ECOGUÍAS Y CONCESIONARIOS}

Tensiones en torno a la conservación ambiental, el uso de la tierra y el trabajo en Guasca, Cundinamarca 


\section{Rojas Arias, Felipe}

Ayer mineros, hoy ecoguías y concesionarios : tensiones en torno a la conservación ambiental, el uso de la tierra y el trabajo en Guasca, Cundinamarca / Felipe Rojas Arias. - Bogotá: Editorial Universidad del Rosario, Escuela de ciencias Humanas, 2015.

208 páginas. - (Colección Opera Prima).

ISBN: 978-958-738-588-5 (rústica)

ISBN: 978-958-738-589-2 (digital)

Conservación del medio ambiente / Uso de la tierra / Naturaleza / Trabajo / Economía - Guasca (Cundinamarca, Colombia) / I. Título / II. Serie.

333.72

Catalogación en la fuente - Universidad del Rosario. Biblioteca

$\mathrm{amv}$

Marzo 4 de 2015

Hecho el depósito legal que marca el Decreto 460 de 1995 


\section{AYER MINEROS, HOY ECOGUÍAS Y CONCESIONARIOS}

Tensiones en torno a la conservación ambiental, el uso de la tierra y el trabajo en Guasca, Cundinamarca

FELIPE ROJAS ARIAS 


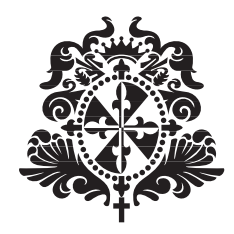

Colección Opera Prima

(C) Editorial Universidad del Rosario

(C) Universidad del Rosario, Escuela de Ciencias Humanas

(C) Felipe Rojas Arias

Editorial Universidad del Rosario

Carrera $7 \mathrm{~N}^{\circ}$ 12B-41, oficina 501

Teléfono: 2970200 ext. 7753

http://editorial.urosario.edu.co
Primera edición: Bogotá D.C., abril de 2015

ISBN: 978-958-738-588-5 (rústica)

ISBN: 978-958-738-589-2 (digital)

Coordinación editorial:

Editorial Universidad del Rosario

Corrección de estilo: Irina Florián

Diseño de cubierta y diagramación:

Kelly Johanna Narváez L.

Impresión: Xpress estudio gráfico.

Impreso y hecho en Colombia

Printed and made in Colombia

Fecha de evaluación: 14 de abril de 2014

Fecha de aceptación: 18 de noviembre de 2014

Todos los derechos reservados. Esta obra no puede ser reproducida sin el permiso previo por escrito de la Editorial Universidad del Rosario. 


\section{Contenido}

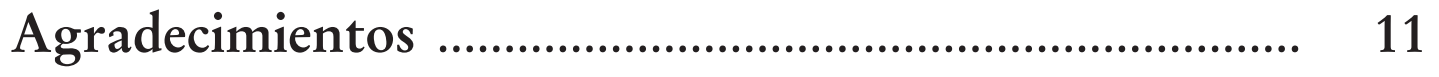

Introducción .............................................................. 13

Capítulo I. Naturaleza, comunidades y conservación .. 27

Las relaciones entre los seres humanos y la naturaleza, un campo de disputa ..................... 27

Comunidades locales y manejo de recursos naturales 55

Capítulo II. El trabajo en Pueblo Viejo: conservación ambiental y oportunidades laborales....................... $\quad 75$

El trabajo en el sector hoy en día: dificultades y añoranzas ......................................................... $\quad 76$

El trabajo en la Reserva Biológica Encenillo: una misma tierra, labores distintas

97

Capítulo III. Los usos de la tierra en Pueblo Viejo: un mismo suelo, aprovechamientos distintos ........ 131

Los usos locales de la tierra ......................................... 132

Tensiones por el uso de la tierra en la Reserva

Biológica Encenillo........................................... 136

Propuestas de los pobladores locales para el uso de la tierra, zonificación y articulación de usos “tradicionales" y usos de la conservación ...... 163 
Conclusiones.

Bibliografía

\section{Figuras y tablas}

Figura 1. Mapa veredal del municipio de Guasca

y área de trabajo de campo

Figura 2. El horno de cal construido por la familia

Hoeck en la década de 1940. Nótese el contraste

con la vegetación a su alrededor

Figura 3. Dibujos de la naturaleza elaborados

por los niños de la IEDC, sede Rodríguez Sierra.........

Figura 4. Tipos de trabajo remunerados

en Pueblo Viejo............................................................ $\quad 78$

Figura 5. Mina de cal en el año 1955.................................. 94

Figura 6. La mina de cal hacia el año 1963 .......................... 95

Figura 7. Usos de la tierra en Pueblo Viejo......................... 133

Figura 8. Zonas restauradas bajo el patrocinio

de actores privados, en este caso universidad que patrocina la siembra de árboles

Tabla 1. División del trabajo por género y familia en Pueblo Viejo. 
Para Ani y Martín 



\section{Agradecimientos}

Especiales agradecimientos a mi director Carlos Del Cairo Silva por sus comentarios, correcciones, ayuda y enorme compromiso. A Diana Bocarejo, Diana Ojeda y Nadia Rodríguez por sus comentarios y correcciones a este texto. A las familias de Pueblo Viejo por su colaboración desinteresada y paciente a este trabajo, por abrirme las puertas de sus casas y por su enorme generosidad y atención: a doña Lucy y don Luis; a doña Cecilia, doña Hermencia y doña Marta; a doña Eloísa y doña Teresa; a doña Ana María; a doña Beatriz y doña María Eloísa; a doña Flor; a don Erlin y doña Rosa; a don Francisco, doña Aura, doña Rosa, doña Teresa y don José; a doña Graciela, doña Elsa, doña Mercedes, don José Ignacio y doña Josefina; a la profesora Clara Isabel y a Amparo; a doña Adela y don Baudilio; a don Jesús; a los niños y niñas de la Institución Educativa Departamental El Carmen (IEDC), sede Rodríguez Sierra. A la Fundación Natura Colombia por su ayuda, tiempo invertido, por la información suministrada y por su amable atención: a don Carlos Castillo, a don Jaime y a doña Lucía. A don Hendrik Hoeck por brindarme su apoyo, tiempo y valiosa información. A la familia Ardila Tovar por su atención, ayuda y compañía. A la familia Ramos Ardila por su indispensable apoyo para 
el desarrollo del trabajo de campo. A mis padres Jaime y Yanira por su apoyo en estos años y su ayuda económica; a mi hermana Paola. Finalmente, a Ana María Ramos Ardila por brindarme consejo, ayuda y apoyo, por su paciencia y esfuerzo, por acompañarme durante el trabajo de campo y aportar con sus ideas, por ser mi soporte y guía. Muchas gracias a todos aquellos que de alguna u otra forma colaboraron en esta investigación. 


\section{Introducción}

En mi primera visita al sector de Pueblo Viejo ${ }^{1}$ tuve la siguiente conversación con una habitante de la vereda, vecina de la Reserva Biológica Encenillo (RBE):

La reserva tiene 200 hectáreas, de las cuales 180 son bosque y 20 son pastos en los que se practica ganadería controlada. La Fundación Natura Colombia [FNC] arrienda estas tierras para que el ganado paste [vende pastos]. Este pastoreo se hace en terrenos delimitados para que las vacas no se metan al bosque. Esta zona donde está ubicada la reserva antes era calicera. Más o menos hace 20 años ya no funciona la mina de cal. La fundación ${ }^{2}$ [Natura], desde la constitución de la reserva, ha empezado a reforestar. (Felipe Rojas, fragmento de nota de campo del viernes 4 de mayo de 2012, cursivas del autor)

1 La vereda Trinidad del municipio de Guasca (Cundinamarca) se divide en cuatro sectores, a saber: Betania, Pericos, Pueblo Viejo y San Francisco. Esta investigación tuvo lugar en el sector de Pueblo Viejo.

2 A lo largo de este trabajo, me refiero a la Fundación Natura Colombia (FNC) en su conjunto como institución. No obstante, no desconozco que las tensiones y relaciones presentes en la vereda no son con la institución en general, sino entre sus funcionarios que trabajan en la Reserva Biológica Encenillo (RBE) y la población local. En este sentido, aclaro que cuando hablo de la FNC me estoy refiriendo a sus funcionarios que laboran en la reserva de Pueblo Viejo. 
Este fragmento de nota de campo contiene una serie de elementos señalados en cursiva que resultan interesantes para explorar el uso de los recursos naturales, las actividades económicas locales y los cambios en las relaciones humanos-naturaleza en Guasca, de los que se derivan una serie de tensiones por el uso de la tierra, la representación de la naturaleza y el trabajo entre diferentes actores. Son precisamente estas tensiones las que constituyen el objeto de estudio de este texto.

Pero ¿cómo llegué a este lugar? En el mes de abril del año 2012 confronté una pregunta sustancial para mi vida académica y personal: ¿qué hacer de tesis? Conocía el municipio de Guasca (Cundinamarca) desde hacía un par de años porque allí vive mi familia política. Interesado por los temas rurales tomé la decisión de hacer mi trabajo de grado en este municipio porque ya lo conocía y tenía algunos contactos en la región. Los meses de abril y mayo de ese año fueron de exploración. Estaba preocupado por plantear un problema relacionado con conflictos ambientales en grupos campesinos. Así, durante este mes recorrí las veredas de Santa Bárbara, Pastor Ospina, La Floresta y Santa Ana (figura 1).

Finalizando mayo, cuando viajaba en un bus que me llevaba de regreso a Bogotá, me percaté que en el sector conocido como El Salitre, ubicado en la vereda que lleva el mismo nombre, había una valla de la Fundación Natura 
Figura 1. Mapa veredal del municipio de

Guasca y área de trabajo de campo

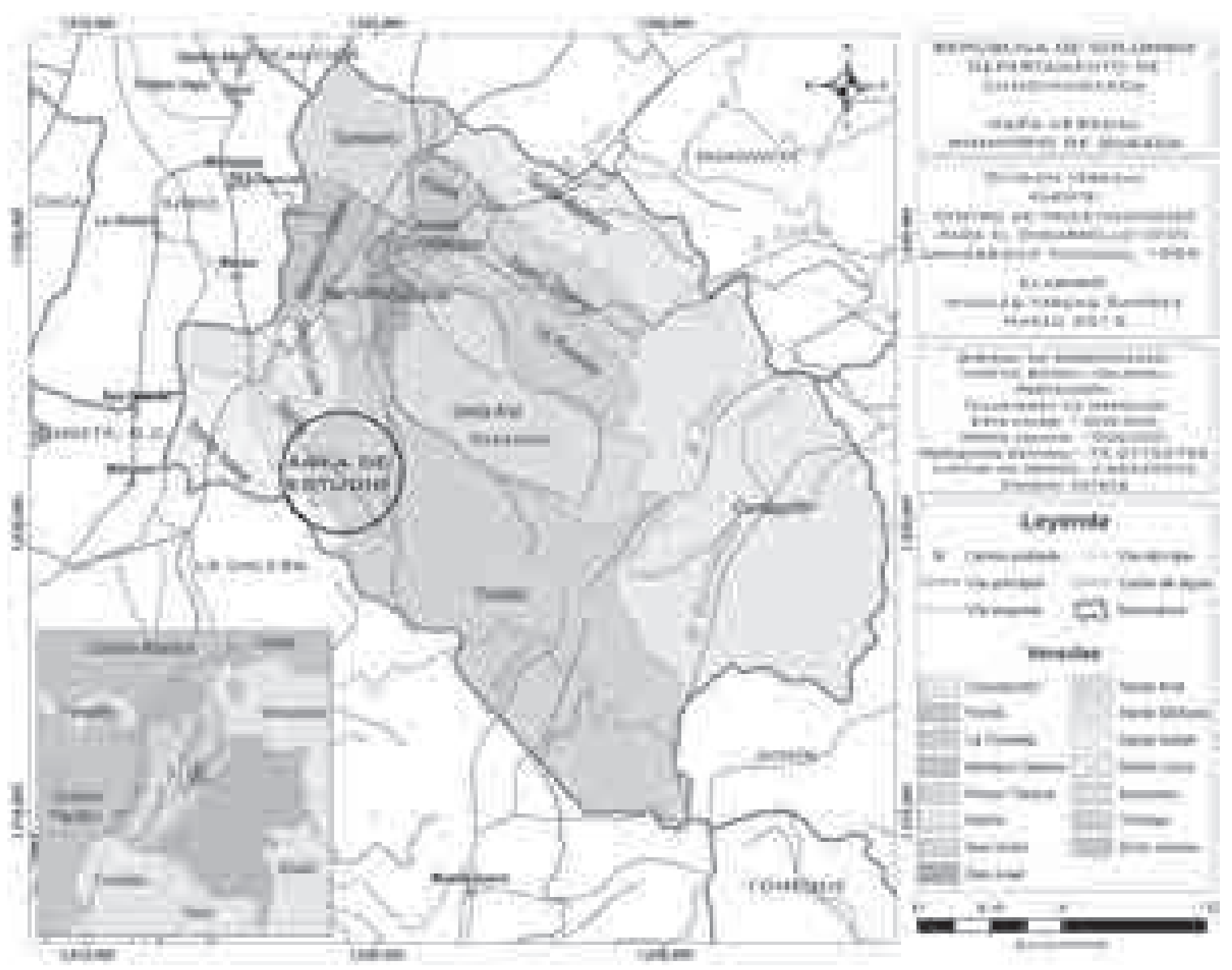

Fuente: elaboración de Nicolás Vargas con base en mapa veredal del municipio de Guasca, Centro de Investigación para el Desarrollo (CID), Universidad Nacional de Colombia, 1999.

Colombia (FNC) que publicitaba la Reserva Biológica Encenillo. El anuncio hablaba de "experiencias en buenas prácticas agrícolas", camping, caminatas ecológicas, yoga, entre otros. Para mífue una "iluminación en campo". Fue la aparición de una posibilidad analítica interesante en comparación con los problemas de investigación que había identificado en las veredas recorridas hasta el momento. 
Días después fui a El Salitre y emprendí mi ascenso a la RBE. Al lado de la vía había bosques por donde se escuchaba el constante goteo del agua y avisos promoviendo el cuidado y la conservación del líquido instalados por la Junta de Acción Comunal de El Salitre. El ascenso fue duro, aproximadamente 5 kilómetros cuesta arriba. Cuando iba en el kilómetro 1, ya me asomaba a una casa a preguntar si ya casi llegaba a la RBE. La repuesta fue desalentadora. Finalmente, llegué a Pueblo Viejo (sector que colinda con El Salitre y pertenece a la vereda Trinidad), luego de casi una dura hora de camino a pie cuesta arriba. Una de las primeras cosas que llamó mi atención fue un enorme horno que sobresalía entre los árboles, justo al lado de una casa que tenía el aviso de "Administración de la Reserva Biológica Encenillo" (figura 2). Esta monumental estructura es un vestigio histórico material de lo que fueron seis décadas de explotación calicera en la región.

Figura 2. El horno de cal construido por la familia Hoeck en la década de 1940. Nótese el contraste con la vegetación a su alrededor

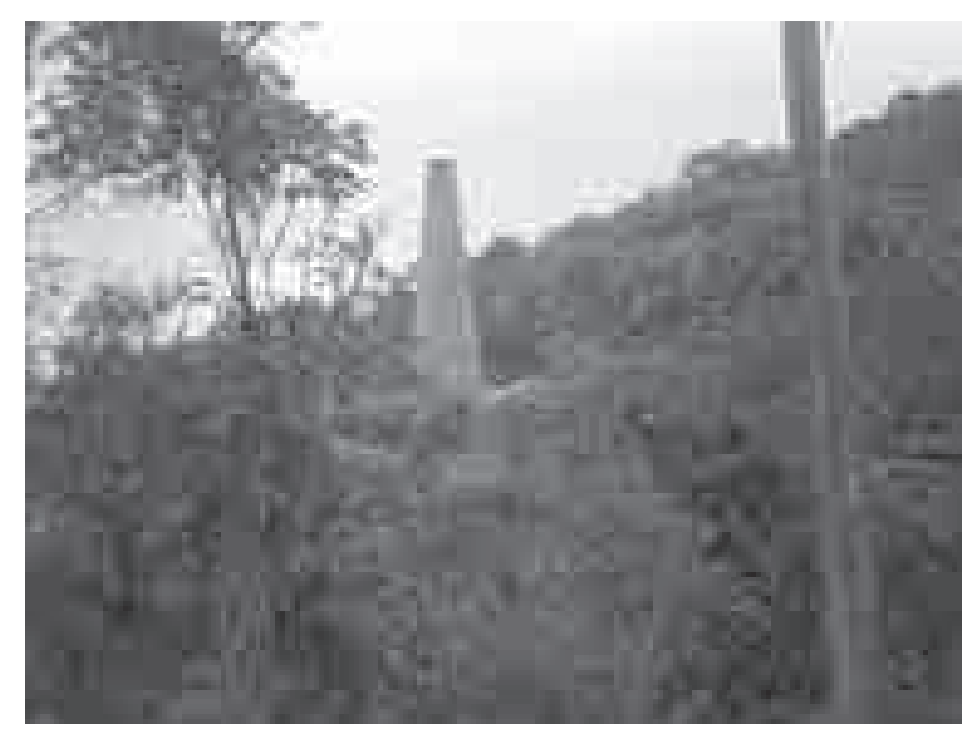

Fuente: Felipe Rojas, 2012. 
La existencia de la mina no solo configuró el paisaje, sino que posibilitó la existencia de la RBE. Las tierras en donde está ubicada esta reserva pertenecieron a una familia de ascendencia alemana (familia Hoeck) que fue la principal accionista de la compañía explotadora de cal, empresa que explotaba el mineral y cultivaba papa y trigo en la región, en especial en el sector de Pueblo Viejo. A primera vista, resulta paradójico que la existencia de una mina haya posibilitado la constitución de una reserva privada de la sociedad civil, es decir:

Parte o todo [sic] el área de un inmueble que conserve una muestra de ecosistema natural y sea manejado bajo los principios de sustentabilidad en el uso de los recursos naturales y que por voluntad de su propietario se destina para uso sostenible, preservación restauración a largo plazo. Corresponde a la iniciativa del propietario del predio, de manera libre, voluntaria y autónoma, destinar la totalidad o parte de su inmueble como reserva natural de la sociedad civil. (Ministerio de Ambiente, Vivienda y Desarrollo Territorial, 2010, p. 23)

La familia Hoeck compró gran cantidad de tierras en la región para explotar el mineral y desarrollar ciertas actividades económicas y pecuarias; predios que fueron donados posteriormente para constituir la RBE. Las extensiones de tierra de la familia Hoeck en el sector permitieron la posterior constitución de la RBE, no solo por el régimen de propiedad privada que reposaba sobre ellas, sino por los usos que esta familia dio al bosque. En una conversación con Hendrik 
Hoeck, donador, junto con su hermana, de las tierras en donde se constituyó la RBE, me comentó que su padre (Hermann Hoeck) había conservado en buen estado los bosques de encenillo que había en Pueblo Viejo. Pese a las disputas familiares sobre cómo disponer de estos bosques, después de la muerte de Hermann Hoeck, la familia convino en conservarlos y no extender la explotación minera.

Así las cosas, y teniendo en cuenta los cambios que se han configurado en esta vereda, me pregunto ¿qué tensiones surgen en cuanto al trabajo y los usos de la tierra a partir de la promoción de la conservación ambiental, agenciada por la FNC en la RBE, entre los funcionarios de esta institución y los habitantes del sector de Pueblo Viejo? El argumento central de este texto es que la declaratoria de áreas protegidas privadas, como práctica suscrita al discurso ambientalista global, más que un proceso neutro o con significados únicos, es una fuente de tensión constante entre pobladores locales y administradores de las zonas de conservación ecológica por cuenta del manejo territorial y ambiental, el entendimiento del uso de los recursos naturales y la naturaleza, la propiedad, el empleo y la descentralización del poder estatal.

Dentro de este gran debate surgen varias discusiones que desarrollaré en este trabajo: 1, Las formas antagónicas de entender la naturaleza y el territorio entre la población y la FNC. Cuestiono los enfoques clásicos de estudio del campesinado y las políticas oficiales que entienden este sujeto solo como económico, en contraste con nuevas tendencias en la teoría social que procuran comprender su apropiación territorial y su simbolización de la naturaleza. Asimismo, 
analizo los contrastes entre las vocaciones ambientales adjudicadas a indígenas y a campesinos y sus implicaciones para la participación en el manejo ambiental. 2, La restricción y el cambio en las formas de usar los recursos naturales por cuenta de la declaratoria de la RBE, en contraste con los usos "tradicionales" que los ocupantes de Pueblo Viejo han dado a su entorno. Dentro de este debate, resalto las discusiones frente al manejo ambiental incluyente y el excluyente, en el marco de las discusiones sobre las implicaciones de un manejo comunitario de recursos; la constitución de áreas protegidas privadas como propuesta neoliberal; el cambio histórico en el uso de recursos naturales; los contrastes entre usos agropecuarios-mineros y usos conservacionistas, y las relaciones entre políticas ambientales y políticas de la diferencia. 3, La calidad y cantidad de oportunidades laborales que puede brindar la conservación ambiental basada en el ecoturismo. Dentro de este debate destaco las implicaciones del ecoturismo como práctica económica de las áreas protegidas y su relación con el mercado y la privatización de la naturaleza; la creación de sujetos ambientales a través del ecoturismo; las relaciones entre género y trabajo, $\mathrm{y}$ los contrastes entre labores agropecuarias-mineras y las conservacionistas.

La constitución de áreas protegidas puede ser vista como una forma de avance en la protección del ambiente. Sin embargo, el cuidado ambiental a partir de la declaratoria de áreas protegidas no puede desligarse de relaciones políticas, conflictos y tensiones, es decir, no es tan neutro como se le quiere presentar. 
Las poblaciones locales se pueden ver afectadas tanto por la destrucción ambiental como por su protección. Caracterizar cómo se están dando estos problemas es clave para fomentar procesos de manejo ambiental incluyente, entendidos como mecanismos de descentralización del manejo de recursos naturales a través una verdadera participación, que democraticen su aprovechamiento, acceso y beneficio. Las poblaciones locales están en el derecho de manejar sus territorios y recursos naturales, tal como lo han venido haciendo. El problema del caso de Guasca radica en que sujetos externos, bajo el amparo de la propiedad privada, llegan a sus lugares de habitación modificando y entrando en tensión con las formas de relación y entendimiento de la naturaleza y de los usos de los recursos naturales.

La perspectiva analítica que guía este trabajo es la ecológica política antropológica. Con ello me refiero a una antropología que si bien se interesa por las relaciones entre los humanos y su entorno, las sitúa en contextos globales, locales y regionales, así como en relaciones de poder; esto es, desigualdades y tensiones sobre las formas de representar la naturaleza y determinar los usos, el acceso y los beneficios sobre los recursos naturales. Si bien a nivel metodológico el escenario de estudio de este trabajo fue de escala local, traté de establecer diálogos con otros casos en otras regiones y países con el ánimo de dar cuenta de la multiplicidad de escalas de los fenómenos estudiados. Además, tuve en cuenta elementos de la legislación y la política local y nacional que me permitieron tener una mirada más amplia de los procesos analizados. En consecuencia, los debates que mencioné líneas atrás se 
estudian en diálogo con procesos de mayor escala como la precarización del trabajo rural, el auge del neoliberalismo y la aplicación de políticas de conservación, en particular las relacionadas con la declaratoria de áreas protegidas, entre otros.

Otro elemento fundamental del enfoque antropológico es su perspectiva etnográfica. Para ser más específico, desarrollé un trabajo etnográfico propio de la ecología política antropológica que implica "un acercamiento cuidadoso a cómo se están dando, en lugares específicos, las construcciones culturales y ambientales, los conflictos, las luchas y los consensos sobre los significados y las prácticas ambientales" (Ulloa, 2001, p. 210). En esta investigación desarrollé observaciones de las actividades cotidianas, agropecuarias y labores tanto de los habitantes como de la FNC en Pueblo Viejo. ${ }^{3}$ Estas observaciones las llevé a cabo en las fincas y viviendas de los habitantes locales por medio de las interacciones cotidianas que entablé con ellos, en las vías públicas de la vereda, en la casa de visitantes de la FNC, en la casa del administrador residente de la reserva y en los predios de la RBE.

Más específicamente, los aspectos que seguí en campo fueron las prácticas ambientales cotidianas, esto es, formas de uso de la tierra, tipos de huertas, tipos de pastoreo, tipos de cultivos, formas de arriendo de terrenos y venta de pastos; uso del agua y la leña; rutinas diarias; prácticas ecoturísticas y otras actividades desarrolladas en la RBE; opiniones

3 El trabajo de campo de esta investigación se desarrolló entre los meses de mayo y septiembre de 2012 con visitas periódicas semanales de entre uno y cuatro días. Posteriormente, en el mes de diciembre de 2012 se desarrollaron visitas más prolongadas que implicaron una mayor estadía en el municipio. 
sobre los usos de los recursos y la naturaleza; relaciones entre la religiosidad y las formas de entendimiento del ambiente; composición de los grupos familiares y las labores de sus miembros, y relaciones laborales entre la población y la FNC.

En segundo lugar, apliqué entrevistas semiestructuradas $^{4}$ a los habitantes locales y a los funcionarios de la FNC. Con ellas pretendía profundizar en sus discursos sobre las formas de entender la naturaleza y los usos de los recursos naturales; sus percepciones sobre el empleo en la vereda; sus motivaciones y expectativas con respecto a la RBE; sus reparos frente a la RBE; las memorias locales sobre la mina, a saber, los usos de los recursos naturales cuando funcionaba la explotación y las características de los empleos que esta ofrecía, y conocer cuál es el plan de manejo de la RBE y la visión de la FNC sobre la población local en relación con la reserva. También desarrollé algunas actividades con los niños en la IEDC, sede Rodríguez Sierra, que sirvieron de base para la recolección de algunos de los datos presentados en las tablas y figuras del capítulo II, así como unos dibujos de representación de la naturaleza abordados en el capítulo I como insumo etnográfico.

$4 \quad$ Este tipo de entrevista cuenta con un guión previo, pero es flexible en tanto su secuencia y orden de pregunta dependen del desarrollo mismo de la interacción. En este tipo de entrevista el investigador si bien propende a indagar ciertos puntos específicos (determinados por el guión), privilegia la escucha. Las entrevistas semiestructuradas que realicé estaban orientadas por guiones de entrevista no rígidos, aunque enfocados en unos aspectos de interés particular y unas variables propias de la investigación: usos de la tierra, concepciones de naturaleza, opiniones frente a la conservación y el empleo, entre otros. 
La relevancia del estudio de los problemas asociados a la conservación que acaecen en Guasca en cuanto al trabajo, las concepciones de la naturaleza y el uso de los recursos ambientales está acorde con los actuales debates de la ecología política y, en particular, su diálogo con discusiones y perspectivas de la antropología rural. Propende por el estudio detallado de los problemas ambientales a partir del influjo de discursos globales de conservación sobre lugares particulares, por lo que Guasca se convierte en escenario clave, pues allí han anclado discursos conservacionistas que alteran sus formas de trabajo, concepciones de la naturaleza y usos de los recursos. Por otra parte, el análisis de este tipo de problemas en Guasca se justifica en la medida en que brinda elementos interesantes para la comprensión de las representaciones locales de la naturaleza, muy pertinentes para el cuestionamiento de ideas esencialistas del campesino como sujeto carente de producción de significados sobre su entorno. No solamente es pertinente porque tal indagación ha estado un tanto ausente de los estudios antropológicos, sino porque permite pensar a unos sujetos no solo como actores económico-productivos, sino como poseedores y productores de cultura y representaciones. Esto puede contribuir a la "reconceptualización" del campesino que se ha propuesto desde algunas investigaciones recientes en la antropología y las ciencias sociales, como por ejemplo las de Ruiz (2010) o Bocarejo (2011). Por esta razón, este trabajo enfatiza tanto en aspectos materiales (uso de los recursos naturales y trabajo) como en simbólicos (concepciones de naturaleza), entendiendo que son indisociables. 
En adición, este trabajo contribuye al cuestionamiento de los beneficios intrínsecos del ambientalismo y, en este sentido, a su estudio como parte de las nuevas problemáticas que enfrenta la ruralidad en conjunción con fenómenos históricos como la propiedad y el trabajo. Pensar cuáles son las implicaciones políticas, económicas, culturales y sociales de los movimientos y las políticas ambientales se hace necesario, en especial si se tiene en cuenta que este discurso ha tomado mucha fuerza a nivel planetario en las políticas públicas, las prácticas cotidianas, la legislación, entre otros. De tal suerte que el caso de Guasca toma relevancia en la medida en que es un escenario en donde tales implicaciones pueden ser rastreadas y analizadas. Lo acontecido allí permite discutir los modelos de gobernanza ambiental, las formas de uso de los recursos del entorno, el empleo en áreas de conservación ambiental y las formas de entendimiento de la naturaleza. Así es que analizar lo sucedido en Guasca es pertinente en tanto los fenómenos que acontecen allí dan pie para la discusión de conceptos y metodologías que posibiliten un estudio crítico del ambientalismo, sus conceptos asociados y sus efectos en la ruralidad. El presente estudio consiste en analizar las implicaciones que este discurso global está teniendo sobre las vidas de los habitantes del campo, en especial aquellos aledaños a áreas protegidas, pues estas zonas son escenarios de mayor influencia del ambientalismo.

Para dar cuenta del problema de investigación planteado, este trabajo se divide en tres capítulos, cada uno de los cuales se orienta hacia la discusión de tres problemas analíticos, a saber: las tensiones por el manejo y aprovechamiento de 
recursos naturales, las tensiones por el trabajo en áreas protegidas y los esencialismos sobre los campesinos y su relación con el entorno.

El capítulo I se divide en dos partes; en la primera, abordo algunos de los problemas y las discusiones conceptuales asociados a las formas de pensar las relaciones humanosnaturaleza; resalto algunas de las implicaciones y tensiones que ciertas formas de pensar el entorno generan en Pueblo Viejo y cómo contribuyen a nivel conceptual; en la segunda parte, abordo los principales debates sobre el manejo de recursos naturales basado en comunidades (CBNRM, por su sigla en inglés), a partir de una perspectiva internacional, para luego discutir sus efectos y matices en Colombia. Los modelos de gobernanza ambiental contra la conservación excluyente toman relevancia en esta sección, así como el neoliberalismo y su relación con la naturaleza.

En el capítulo II caracterizo las formas de trabajo en Pueblo Viejo y abordo los problemas de desempleo y la falta de puestos de trabajo como algunos de los elementos cambiantes en este sector y relacionados con parte de la situación laboral del campo en Colombia. Adicionalmente, a la luz de esta situación, expongo y analizo las tensiones derivadas de las formas de trabajo ofrecidas por la FNC en Pueblo Viejo. Resalto cómo los actores locales entienden el papel de la FNC como empleador en contraste con la compañía explotadora de cal.

En el capítulo iII realizo una caracterización general de los usos de los recursos ecológicos a escala local, con énfasis particular en la tierra. Posteriormente, analizo las tensiones 
que se derivan de las diversas concepciones de usos de los recursos naturales entre los pobladores locales y la FNC, por cuenta de la conservación ambiental. 


\section{Capítulo I \\ Naturaleza, comunidades y conservación}

En este capítulo se discuten algunas de las representaciones que los habitantes de Pueblo Viejo hacen de la naturaleza y el territorio que habitan. Se propone que estos hallazgos en campo suponen un cuestionamiento a la dicotomía naturaleza-cultura y a la conceptualización y el entendimiento economicista sobre los campesinos que niega su simbolización del entorno, como sujetos sociales y como categoría analítica. En la segunda sección de este capítulo, se analizan parte de las políticas de conservación a nivel global y nacional, en particular las relacionadas con el manejo de recursos naturales, teniendo en cuenta su conexión e implicaciones para el caso de estudio. De igual manera, se discute sobre la gobernanza como modelo de manejo ambiental actual dentro de lógicas privadas y "participativas" de descentralización del poder estatal. Se finaliza haciendo un análisis de algunas de las implicaciones de la existencia de reservas privadas de la sociedad civil.

\section{Las relaciones entre los seres humanos y la naturaleza, un campo de disputa}

Entre los campesinos de Guasca existen formas de representación de la naturaleza que son útiles para cuestionar la 
dicotomía naturaleza-cultura, que divide a los humanos y a los no humanos en campos ontológicamente distintos. Este dualismo impide establecer continuidades ontológicas entre naturaleza y cultura, y es producido por relaciones y estructuras de dominación y subordinación coloniales, lo cual es problemático porque legitima la desigualdad e imposibilita dar cuenta de cómo la naturaleza y la cultura se coproducen entre sí. Además este dualismo desconoce las complejas relaciones, conexiones e interrelaciones que los seres humanos establecen con su entorno natural o con los no humanos (Del Cairo, 2013; Plumwood, 1993).

Una de las formas en las que se pudo constatar estas representaciones de la naturaleza entre los campesinos de Guasca fue cuando se preguntaba por las implicaciones de la siembra de árboles en los predios de la rbe. Líneas más adelante se elaborará el asunto, pero basta con decir que en buena parte de estos campesinos existe una equiparación entre ciertas formas de naturaleza como la montaña y peligros humanos, no humanos y de salud. El monte no es simplemente una entidad biológica para ellos, sino que, en buena parte, representa peligros para la salud por el frío, las fieras, los ladrones o los guerrilleros -estos sujetos se difuminan con la montaña al acecho para atacar a las personas. En parte de sus opiniones existía una clara y estrecha asociación entre actores humanos y naturales como seres con características compartidas.

Estas representaciones sirven para comprender de qué manera estos campesinos construyen simbologías del entorno en el que viven y le asignan propiedades particulares 
en relación con ciertos sujetos humanos. Pese a estas evidencias, como se reconstruye más adelante, la conceptualización de los campesinos desde lo económico sigue teniendo mayor fuerza, lo que se refleja en la poca existencia de trabajos que cuestionen este materialismo y su peso en la política oficial. Sin embargo, el trabajo de campo reveló datos muy dicientes sobre la existencia de representaciones y simbolizaciones de la naturaleza en los grupos campesinos con los que trabajé en Guasca, muy útiles para cuestionar el economicismo en los análisis sobre esta población. Cuando se preguntaba a algunas personas por su opinión frente a la siembra de árboles en los potreros de la RBE, contestaban con argumentos como el siguiente:

Eso es lo que se siente porque qué tal que como en el Caquetá, allá se apoderó la guerrilla de todo esas montañas. Como la guerrilla tira es al monte, entonces claro que por aquí se va, se irá, Dios nos favorezca que se vaya convertir en casa de la guerrilla. Porque esa gente tira es al monte. Sí, señor [...]. Es que ya estamos en los últimos tiempos. Porque es que en la sagrada biblia está. Ya entonces para los últimos tiempos entonces ya todo se convertirá en bosques y en montañas y ya no habrá ni dónde sembrar ni siquiera una matica de cebolla. En la [biblia] está y palabra de Dios nunca falta. Porque apenas ver ahí monte. Y ahí entonces principian a llegar las fieras, principia a llegar el oso, el león, el tigre. Y lo que dice en la sagrada biblia. No ve que dice que en los últimos tiempos vendrán los animales, las fieras a poseer la casa de los justos. Y los justos irán a poseer la 
ca[sa], la madriguera de las fieras. En la sagrada biblia está. (Entrevista a una señora en sus setenta años, habitante de Pueblo Viejo, 2 de septiembre de 2012)

Este testimonio sitúa elementos interesantes y muy dicientes sobre la manera en que los campesinos piensan los árboles, la vegetación y los animales, que sirven para cuestionar la dicotomía naturaleza-cultura en las sociedades rurales. Los reparos por la siembra de árboles no solo versan sobre motivos económicos (aspecto que se reconstruirá en el capítulo III), sino que hacen parte de consideraciones religiosas y simbólicas sobre las características del bosque como lugar de las fieras, como escenario peligroso que, si no se detiene su crecimiento, puede derivar en consecuencias para la vivienda de las personas. El final de los tiempos -la crisis ambiental- no vendrá según estos testimonios por cuenta de la destrucción de la naturaleza como comúnmente se piensa, sino, por el contrario, por la invasión que aquella haga a los lugares de habitación de los seres humanos. La naturaleza, entonces, es simbolizada como un factor de caos propio del "final de los tiempos". La naturaleza es una región de frontera en la que ocurren hechos violentos y es la casa, el lugar de habitación, de peligros humanos como la guerrilla de las FARC. Este grupo armado es equiparado como peligro per se del monte. Esto quiere decir que se entremezclan entidades humanas y no humanas, pues se concibe que el lugar propio

$5 \quad$ Algunas personas solicitaron que sus nombres no aparecieran citados en este trabajo, mientras que otras dieron su autorización. Sin embargo, en este trabajo se ha preferido no mencionar ningún nombre propio de los habitantes locales. 
de habitación de este grupo armado es el bosque. Esta alusión a grupos armados tiene referentes históricos, los cuales, si bien la vecina no menciona, están presentes en las memorias de algunos pobladores de Guasca.

Hacia los años noventa hubo un auge guerrillero en esta región e, incluso, hechos violentos como el secuestro de un habitante local. Por su parte, esta opinión citada, entre muchas otras, revela que los animales no son solamente seres no humanos, sino que encarnan el peligro en sí mismos, que se representa a partir de la denominación "fiera". La naturaleza, además, es un medio por el cual Dios envía a los seres humanos castigos y peligros propios del fin de los tiempos.

Uno de los objetos clásicos de estudio del pensamiento antropológico ha sido la relación entre naturaleza y cultura. Múltiples trabajos en distintas vertientes teóricas como el materialismo cultural (Harris, 1998), la ecología simbólica (Reichel-Dolmatoff, 1977) o la morfología simbólica (Descola, 2001; 2002), entre otros, han subrayado la manera en que los seres humanos se relacionan con el ambiente que los rodea. Aproximaciones de corte culturalista, materialista y geográfico han guiado estos análisis. En buena medida, su interés ha sido estudiar las formas en que las sociedades interpretan, representan y se adaptan al entorno. Parte de la base de los estudios antropológicos clásicos ha sido el análisis de las diferencias entre la naturaleza y la cultura, toda vez que se concibe lo cultural como aquello que separa a los seres humanos del mundo natural. Sin embargo, trabajos recientes como los de Descola $(2001 ; 2002)$, entre otros, han tratado 
de subvertir la diferenciación raciocéntrica entre el mundo natural y el cultural.

Estos giros en el pensamiento social para el caso de los campesinos han estado relacionados con la forma en que se ha conceptualizado a este sujeto social. Los estudios clásicos, muchas veces bajo argumentos economicistas, enfatizaban en que el campesino era parte de una cultura parcial, se encontraba en relación con el mercado y estaba en el intermedio entre la sociedad folk y la sociedad urbana (Redfield, 1956), además era considerado como un indígena aculturado, un mestizo, que subsiste a partir de las actividades agropecuarias y la apropiación (y arraigo) de la tierra como medio de producción con base en su fuerza de trabajo y la de su familia (Dussán, 1953; Guhl, 1953; Morales, 1966; Tocancipá, 2005; Wolf, 1978).

A pesar de que varios de estos autores consideraban que el campesinado era productor de cultura, no ahondaban en su contenido dentro de las prácticas y los pensamientos campesinos, ni mucho menos en la simbolización del territorio o la naturaleza, pues parte de su énfasis era su estudio como sujeto económico. En adelante, las críticas al economicismo que se plantean se refieren a esta primera corriente de estudio del campesinado en las ciencias sociales y no a todo el pensamiento social en general.

Lo anterior en razón de que la teoría social superó estos economicismos y empezó a interesarse por el estudio de los aspectos de la vida cotidiana, la cultura, la religiosidad y la apropiación territorial de los campesinos. Estos trabajos empezaron a involucrar en la categoría campesino patrones 
culturales bajo categorías como "tradicional" (Shanin, 1979); la religión y las prácticas cotidianas (Fals Borda, 1961) y su relación con la apropiación territorial (Moreno, 2001); la incidencia de la cultura, la magia y las ceremonias en la alimentación y las relaciones entre caza y juego que sugieren reflexiones de la relación naturaleza-cultura más allá de lo material (Dussán, 1953; Mora, 1974); la simbolización de la naturaleza (Ruiz, 2010); la construcción del territorio (Del Cairo, 1998); la elaboración del paisaje a través de la apropiación de recursos naturales en el marco de lógicas culturales (Cano, 2005; Echeverri y Ribero, 2002), y la definición de una identidad social, cultural y política (Tocancipá, 2005).

En consecuencia, la categoría campesino sufrió un cambio desde una posición puramente económica a una cultural al interior de la teoría social. Al llevar un poco más allá esta genealogía teórica, se considera que este cambio sugiere que la naturaleza y la cultura trascienden en categorías centrales en el estudio de las formas de vida y la conceptualización del campesino.

Una de las premisas que sustentó la antropología emergente del siglo xix fue su separación de las ciencias de la naturaleza al erigirse como la ciencia de la cultura. Aunque actualmente el pensamiento que diferencia entre el mundo natural y el cultural, propio de la Modernidad, sigue imperando, diversos académicos y corrientes teóricas han tratado de deconstruir la díada naturaleza-cultura. Las teorías posmarxistas, posmodernas y postestructurales critican la existencia de una sola forma de entender la naturaleza en oposición a la cultura (Biersack, 2011; Escobar, 2010; Ulloa, 
2011), la cual fue una de las bases de sustento del pensamiento antropológico (e incluso de las ciencias sociales) como campo de estudio de la cultura; es decir, de todo aquello que no era dominio de la naturaleza. Así, las teorías actuales en ecología política y antropología ambiental entienden la existencia de múltiples concepciones de naturaleza y relaciones difusas entre el mundo humano y el natural, como dominios estrechamente interrelacionados y coproducidos.

Los modelos locales de naturaleza estudiados por los antropólogos sirvieron como base para encontrar conceptualizaciones que no diferenciaban entre lo humano y lo no humano, es decir, fueron parte del sustento empírico para cuestionar el dualismo propio de la racionalidad moderna. En Guasca, este sustento empírico para cuestionar la dicotomía naturaleza-cultura es evidente en diferentes opiniones como la siguiente:

Porque la idea sería esa, estar ahí uno como pendien[te], [la naturaleza] es como un hijo. A veces les digo yo a la gente, las planticas son como un hijo. Uno, uno las siembra pero tiene que estar ahí, por lo menos mirando a ver porque si lo deja abandonado no ve que se pierde, si no lo cuida [...]. (Entrevista a habitante de Pueblo Viejo, 13 de agosto de 2012)

Esta opinión se enmarca en los reparos de esta persona sobre el cuidado que la FNC hace de los árboles que siembra en los potreros de la RBE. Su afirmación permite pensar cómo entidades humanas y no humanas se mezclan. No se 
trata simplemente de un ejemplo cualquiera, pues tiene que ver con la forma en que los seres humanos se relacionan con el entorno. Esta opinión supone una relación de cuidado, y una forma de percibir como frágiles a algunas entidades de la naturaleza que, para estos efectos, se pueden equiparar a los niños. La comparación entre los niños y los árboles da cuenta de una continuidad entre ciertas propiedades humanas y de la naturaleza; en este caso, la fragilidad y la necesidad de ser cuidados y protegidos.

Pero este constructivismo de la naturaleza ha sido también criticado por su alejamiento de la realidad material, al punto de que se han planteado propuestas que algunos autores han denominado "posconstructivistas" (Escobar, 2010). Parte de la base de este enfoque analítico consiste en volver a "lo real", esto es un neorrealismo (realismo no esencialista) que no desconoce la ontología específica de las realidades biofísicas, a diferencia del constructivismo (Escobar, 2010).

Si bien otro tipo de autores no utilizan estas denominaciones, consideran la existencia de mutuas determinaciones entre cultura y naturaleza (Ulloa, 2002; 2011) como forma de superar los determinismos materiales y culturales. En consecuencia, considero que el neorrealismo está dando un nuevo giro en las consideraciones sobre la naturaleza. El proceso deconstructivo pretendió socavar el dualismo y le extrajo sus referentes materiales al situarlo en el plano discursivo. Así, las nuevas propuestas sobre el estudio de la naturaleza proponen volver a lo "real", no desde postulados materialistas, sino entendiendo que el mundo es tanto físico como simbólicamente determinado. Las relaciones que los 
seres humanos entablan con su entorno no solamente son del dominio de las prácticas o del pensamiento, no implican solamente el mito, las representaciones o simbologías, sino también la materialidad y los procesos biofísicos.

Pero este cuestionamiento al dualismo naturaleza-cultura no tuvo un efecto similar en los diversos estudios antropológicos y en las políticas públicas. Mientras en las investigaciones con grupos indígenas esta díada ha sido más ampliamente cuestionada, en las comunidades campesinas, en general, se han pasado por alto sus simbologías frente a la naturaleza. Así, muchas investigaciones antropológicas han establecido que solo son los grupos indígenas los que poseen categorizaciones monistas de la naturaleza. En consecuencia, estas discusiones teóricas que se han reconstruido permiten introducir el problema de las relaciones que los grupos campesinos entablan con su entorno.

A partir de un examen de las interpretaciones de la fauna y las prácticas asociadas a la cacería, Ruiz (2010) propone que en los campesinos de La Macarena es posible identificar mediaciones simbólicas con la selva, similares a las de grupos indígenas. Esta es una apuesta interesante que busca superar las visiones economicistas sobre los campesinos.

En el análisis de la relación entre los grupos campesinos y su entorno impera aún una lógica materialista y economicista. Este materialismo viene acompañado de un despojo de la capacidad de significación de la naturaleza en este grupo poblacional. Trabajos como el de Bocarejo (2011) presentan críticas interesantes sobre la manera en que los sujetos étnicos son especializados (arraigados a un espacio) y vistos como tendientes a la protección ambiental, en contraste con los 
campesinos (vistos como no étnicos), que son construidos como tendientes al desarrollo agrícola y carentes de referentes culturales frente a su lugar de habitación. Esta situación es consecuencia del multiculturalismo colombiano que construye sujetos con cultura (indígenas) y sin cultura (campesinos) (Bocarejo, 2011). En otro texto Bocarejo y Restrepo muestran que

[...] otros grupos subordinados, como los campesinos o los sectores populares, no suelen encajar fácilmente en las imágenes de la diferencia cultural que se expresa en el sujeto étnico paradigmático. Esto ha significado que ciertos entramados estatales y las más diversas entidades del país y el extranjero destaquen ciertas voces, personas y colectividades -las que pueden encuadrarse en el sujeto étnico-, mientras acallan o ignoran otras, pues escapan a las formas de legibilidad impuestas por el multiculturalismo. Si tenemos en cuenta la relación entre el multiculturalismo y las formas de la política que promueve, en particular aquella que equipara las demandas políticas con la reclamación de derechos, y los derechos con la reivindicación de la diferencia cultural, encontramos que las poblaciones no reconocidas como étnicas ven sus posibilidades de acción política sometidas a un nuevo régimen de invisibilidad. (2011, pp. 9-10)

De allí la importancia de mostrar que en Guasca existen referentes materiales y simbólicos que intervienen en la concepción de la naturaleza en medio de relaciones de poder, 
en este caso entre la RBE y la población, como se ha mostrado hasta el momento a través de los ejemplos empíricos presentados. La primera cita lo demuestra, pues hay un contraste entre la producción material - “y ya no habrá ni dónde sembrar ni siquiera una matica de cebolla" por cuenta de la siembra de árboles en la RBE- y la simbólica, que habla del peligro de los animales del bosque y el final de los tiempos.

Estas consideraciones conducen a plantear que para el estudio de las relaciones entre los campesinos y su entorno, no basta con invertir el asunto y considerar elementos puramente representacionales, ni continuar bajo premisas economicistas de estos sujetos rurales. El asunto versa sobre el entendimiento de las mutuas determinaciones que elementos "biofísicos" (Escobar, 2010) y elementos propios del pensamiento generan en la relación con la naturaleza.

Hasta el momento en este texto se ha posicionado el argumento hacia la consideración de una naturaleza múltiplemente significada y enmarcada tanto en lo material como en lo simbólico, pues ello se ve en las formas de entendimiento del monte y la montaña en Pueblo Viejo. Adicionalmente, con base en los ejemplos empíricos, se propone que estas formas de apropiación del entorno no solo pertenecen a los grupos étnicos o indígenas, sino que también se hacen presentes entre los campesinos.

Ahora se discutirá cómo estas representaciones tienen un componente diacrónico, espacial y político. Ya se esbozaron algunos elementos que intervienen en el asunto a nivel político en cuanto al reconocimiento de la diferencia cultural; estos conducen a que los sujetos campesinos sean vistos 
como faltos de cultura y, por tanto, carentes de interpretaciones frente a su entorno.

Como lo muestra Bocarejo (2011), estas imágenes esenciales de los grupos campesinos e indígenas tienen implicaciones sobre el desarrollo de sus luchas políticas. Una de las principales consecuencias es la consideración de que los indígenas son sujetos meramente espirituales que no tienen necesidades productivas o materiales, por lo que no son incluidos en proyectos económicos. Los indígenas han sido vistos, desde las políticas de la diferencia, como sujetos hipersimbólicos, carentes de necesidades materiales, mientras que los campesinos han sido construidos como sujetos económicos carentes de motivaciones simbólicas y espirituales.

En Guasca esto tiene consecuencias, pues durante el proceso de constitución de la RBE y en el periodo siguiente, no hubo consulta con la población local. Esto no solo tiene que ver con el régimen de propiedad privada que reposa sobre las tierras de la RBE (que se discutirá más adelante), sino con una legislación que no ampara a los campesinos, pues no son étnicos y, por consiguiente, no tienen que ser consultados para el desarrollo de proyectos en sus lugares de habitación. Además, en Guasca esta idea de los campesinos como económicos fomenta a que no se discutan sus derechos territoriales sobre los predios de la vereda o no se consideren útiles sus conocimientos sobre el entorno para el cuidado ambiental, razón por la cual la FNC no ha desarrollado sesiones de diálogo, consulta o reconocimiento de los saberes campesinos. En buena medida, sus saberes sobre el funcionamiento ambiental son desconocidos a nivel del discurso y la práctica. 
Las representaciones de la naturaleza se ponen en escena y se instrumentalizan con el fin de hacer valer ciertas luchas políticas, como por ejemplo las alianzas entre movimientos ambientalistas e indígenas (Ulloa, 2004). Claramente, la imagen del indígena como simbólico, espiritual y ecológico ha sido una herramienta útil para movilizar sus luchas a falta de otras posibilidades reivindicativas como la pobreza o la falta de oportunidades económicas, consideradas ajenas (o lejanas) a lo indígena y más propias de lo campesino desde las representaciones oficiales de los planes de desarrollo o la legislación.

Hasta el momento, pese a la existencia de formas en que los campesinos de Guasca llenan de contenido la categoría naturaleza, no ha habido procesos que permitan su uso como herramienta política para movilizar sus intereses frente al ambiente. En mi opinión, esto tiene que ver, en parte, con la falta de estructuras de oportunidades para este tipo de reivindicaciones entre los grupos campesinos, a diferencia de los étnicos que cuentan con unas posibilidades de acción política mayormente visibilizadas (Bocarejo y Restrepo, 2011) que les permiten movilizar imágenes ecológicas.

En Guasca, el ambiente es una categoría no solo de subsistencia o representación, sino política. Desde la época en que operó la mina de cal, ha habido luchas en torno a la explotación del recurso, ya sean estas de carácter sindical o por acuerdos y disputas frente a la disposición de sedimentos entre la comunidad y la empresa. Actualmente, existen disputas por la definición del territorio finca, reserva y montaña, así como por el aprovechamiento de los recursos del 
ambiente y el trabajo. Si bien no son luchas directas, existen discrepancias de parte y parte en las que median relaciones desiguales de poder, ya sea por el conocimiento, el derecho de propiedad o la personería jurídica de los actores. Los discursos globales de la conservación aterrizan en este escenario $\mathrm{y}$, junto con sus prácticas, alteran, son modificados, se resignifican y entran en tensión con las formas locales de entender el uso y la forma del espacio y los recursos naturales.

En Guasca, como se analizará a lo largo de este texto, existen disputas frente a la manera de dar uso a la tierra, de entender ese espacio, la vocación del suelo y aquello que se considera se debe conservar de la naturaleza. Se trata de la existencia de diversas formas de entender lo que es la naturaleza, y cómo ello supone tensiones en medio de posiciones desiguales de poder.

Entonces bien, las representaciones y prácticas frente a la naturaleza, que los estudios antropológicos rastrean en campo, se encuentran en diálogo y disputa por lo que se sitúan en procesos políticos en donde el acceso, los beneficios y los costos de los recursos ambientales están mediados por relaciones desiguales de poder (Ulloa, 2001). En suma, el ambiente es político (Ulloa, 2001), lo que quiere decir que no es una categoría prístina y neutra, sino que está imbuido en relaciones de poder, circuitos de mercado y luchas simbólicas y materiales. Así, uno de los aportes de la antropología para el estudio de este tipo de problemáticas es su rastreo etnográfico no solo desde campos materiales y económicos, sino también discursivos. 
Las divergencias por la definición de la naturaleza y el espacio de la reserva entre los habitantes locales y la FNC se pudieron apreciar en diferentes escenarios y situaciones. En una de las visitas a la IEDC, sede Rodríguez Sierra, ubicada en Pueblo Viejo, la profesora Clara Isabel estaba enseñando a los niños diversas "acciones para cuidar la naturaleza" que escribió en el tablero. La que más me llamó la atención fue la que decía: "no pisar los sembrados porque dañamos los cultivos". Las otras dos decían: "no hacer fogatas en los montes" y "no arrojar basuras en los ríos y lagos". Estos consejos para cuidar la naturaleza son una muestra de cómo en las representaciones de la naturaleza en Pueblo Viejo caben los cultivos. Este tipo de actividades agropecuarias (y las especies que de ellas se derivan) y usos del suelo son vistos como parte de la naturaleza que debe ser protegida.

Otra situación en la que pude apreciar estas representaciones fue cuando, en una actividad con los niños (de edades entre 5 y 10 años) de la escuela, les pedí que dibujaran todo aquello que fuera naturaleza. Además de dibujar flora y fauna, nubes y arcoíris, representaron huertas y cultivos como parte de esta, como lo muestran los dibujos de la figura 3.

Nótese en los dos primeros dibujos las "manchas" oscuras con puntos. Las del primero corresponden a un cultivo y las del segundo, a una huerta casera. Estas representaciones de la naturaleza en lo agrícola, como algo que debe ser protegido y cuidado, contrastan con una visión ecologista de conservación ambiental propuesta por la FNC, como la que se deriva del siguiente fragmento de entrevista: 
Figura 3. Dibujos de la naturaleza elaborados por los niños de la IEDC, sede Rodríguez Sierra
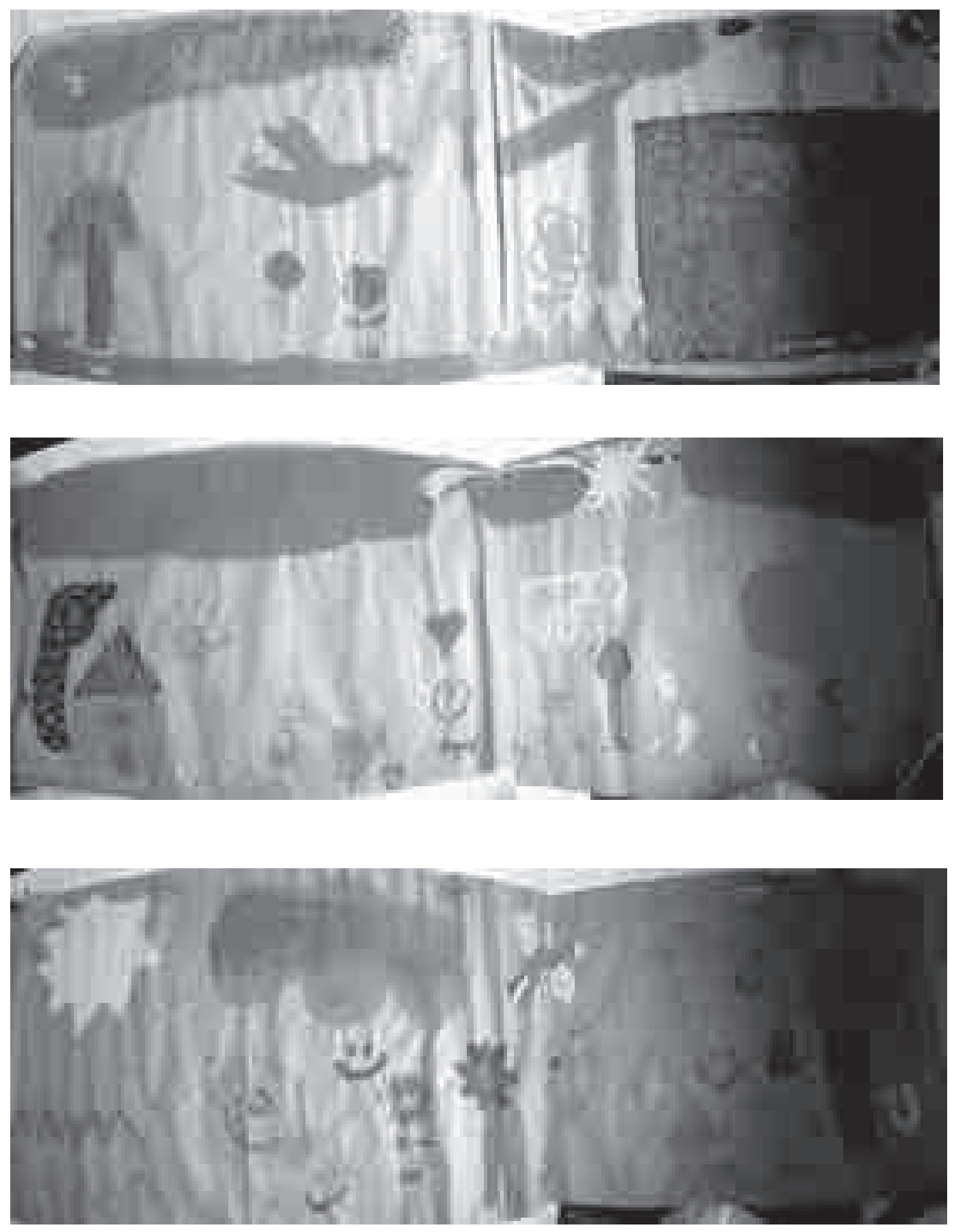
-Felipe Rojas: Y hablando un poco de esa biodiversidad, ¿cuál es la importancia de conservar esos bosques en particular alto andinos?

-Carlos Castillo: Porque son relictos, el bosque alto andino de encenillos solamente existe en la cordillera Oriental. Y la cordillera Oriental es una de las que han sido pues más afectadas por la actividad antrópica, razones culturales, históricas, etc. En Guasca, usted lo ha visto muchas veces, el paisaje siempre conserva bosque, si uno va a otras regiones, incluso en la misma Calera, la actividad antrópica arrasó aquí los cerros orientales de Bogotá, se arrasó con todo el bosque. Pero en Guasca la actividad productiva siempre ha respetado las franjas de bosque. Por eso es que el paisaje está salpicado de claros y bosque, claros y bosque. Entonces es una cosa interesante y eso digamos conduciría a que precisamente sea en Guasca donde queda relicto de bosque alto andino de encenillos, la especie predominante en bosque maduro es la Weinmannia tomentosa, es el encenillo. (Entrevista al jefe de la RBE, 18 de enero de 2013)

En la misma entrevista comentaba:

Porque cuando preferimos digamos como la denominación de reserva biológica porque digamos que el principio es la conservación de la biodiversidad. Es el principio fundamental de la biología. (Entrevista al jefe de la RBE, 18 de enero de 2013) 
Ulloa (2004) presenta una discusión sobre cómo las nociones de biodiversidad separan la naturaleza en partes, e incluso le dan valor económico en el mercado, lo cual resulta en conceptos ajenos a las formas de concebir la naturaleza entre los indígenas de la Sierra Nevada de Santa Marta, pues para ellos hay una indisolubilidad entre los diferentes elementos de la naturaleza y son inconcebibles sin su relación con entidades espirituales.

Para el caso de Guasca, las nociones de biodiversidad presentes en este fragmento introducen un concepto ajeno, jerarquizan las especies a partir de lo que es o no nativo, y por ende benéfico para el entorno, y proponen nombres científicos. Se privilegia una naturaleza ajena a la actividad antrópica, como aquella que debe ser conservada en contraste con las visiones campesinas sobre la necesidad de proteger pasturas, huertas y cultivos como formas de naturaleza.

Es evidente el contraste entre las visiones de la naturaleza englobadas en el concepto de biodiversidad con las que se derivan de las opiniones de los campesinos de Guasca que entienden que la naturaleza es también un cultivo. Este tipo de disputas por el significado de la naturaleza surgen en Guasca por cuenta de las tensiones en torno al uso de la tierra en la RBE, en especial por la siembra de árboles en detrimento de actividades productivas. Las tensiones tienen que ver con la construcción y simbolización de lugares llamados monte y montaña: 
Pues, de pronto, pues sería mejor de verdad que no sembraran muchos árboles porque estamos rodeados todo de monte, de monte y siguen sembrando árboles. Entonces en el año, en los años venideros todo esto será mera montaña, una montaña porque siguen y siguen sembrando árboles. Eso todo queda como una montaña. (Entrevista a vecina del sector, 2 de septiembre de 2012)

Una vecina perteneciente a una familia dedicada a la ganadería lo expresaba así:

Sí, de aquí a un tiempo porque como en el modo que siembran árboles, siembran y siembran árboles y entonces ya pues con el tiempo se forma como una montaña, como puede que sea un buen beneficio, sí, pero de todas maneras, donde eran buenos potreros, pues da como pesar que pues pueda, si por unas partes es bueno, ¿cierto?, pero entonces por unas partes ya se viene formando como mucho, mucha montaña. (Entrevista a vecina de Pueblo Viejo, 27 de agosto 2012)

Según la opinión de algunos vecinos, el monte representa lo que es la naturaleza promovida en la reserva, en contraste con otro tipo de elementos naturales como los cultivos o pasturas. La formación de "mucha montaña" tiene consecuencias sobre las formas productivas locales en la opinión de estas personas. La montaña es una naturaleza no productiva, no benéfica en términos económicos, y peligrosa en cuanto a la seguridad y salud. Con todo, los 
pobladores reconocen el valor de la siembra de árboles para la proliferación de fuentes hídricas, lo que constituye una muestra de que sus motivaciones no son netamente productivas. En este sentido, algunos ven la reserva como un territorio que no se debe prestar para ciertas actividades agropecuarias, como por ejemplo tractorear la tierra. El espacio de la reserva, de acuerdo con algunas opiniones, no pertenece a este tipo de aprovechamientos agrícolas:

No, para agricultura si no. No, igual me pienso yo que una, es una reserva y cómo van a tractorear la tierra. Sí, en pastoreo como va, van bien. (Entrevista a habitante local, 8 de septiembre de 2012)

La noción de biodiversidad introducida por la FNC no es muy propia del discurso campesino de la naturaleza en donde predominan categorías como "bosque", "monte" y "montaña”, que hacen referencia a la naturaleza no dominada. En varias de las entrevistas, se pudo constatar que "el monte" y "la montaña” se creaban por cuenta de la expansión del bosque a partir de la siembra de árboles en los potreros o su crecimiento natural. Esto representaba una preocupación para los vecinos, pues consideran que de acá a un tiempo, en el ritmo de siembra que propone la FNC, todo se convertirá en "montaña".

Tal parece que "monte" es una naturaleza que está junto a las personas y sus fincas, pues provee sustentos como madera o agua, define el límite de la finca e, incluso, puede llegar a estar en su interior. Por su parte, en los términos de estos 
vecinos, la categoría de “montaña” es un bosque más grande que puede llegar a imposibilitar la existencia de las fincas, es una forma de naturaleza más lejana, peligrosa, amplia e indómita. Así, no solo existe una tensión a nivel laboral y económico entre la FNC y la población local como se describirá y analizará en los dos siguientes capítulos, sino también en las formas de entender la naturaleza y el territorio.

En este sentido, al sembrar tantos árboles y permitir la extensión de la montaña, los vecinos consideran que la FNC estaría convirtiendo una finca (como territorio) en montaña, lo cual genera tensiones con la población local:

[Algunas personas] pues están comprando [pastos a la FNC]. [...] Como arriba al lado de los alisos han comprado varios, como don Eduardo ${ }^{6}$ compra pastos, los señores que viven ahí en la tienda de abajo también compran los pastos. Pero a lo que ya se tape todo, de verdad que están sembrando muchos árboles es arriba, donde hay todas esas fincas, de verdad quedan sin pasto la gente, acaban con las vacas. (Entrevista a pobladora local, 8 de septiembre de 2012)

Esta visión equipara al potrero con la finca, esto es, a cierto tipo de naturaleza (pastos) con este espacio. La tensión se deriva de la existencia de potreros en la RBE, los cuales son entendidos por esta persona como fincas o espacios productivos, que se acabarían en el momento en que fueran sembrados por árboles y se extendiera la montaña.

Nombre cambiado. 
Tanto las pasturas como los árboles hacen parte de la flora, pero en la visión de muchos habitantes locales, existe una diferenciación sobre cuál de estos elementos permite la existencia de una finca y cuál la imposibilita.

En muchos de los casos, los pastos, los cultivos y las franjas pequeñas de bosque permiten la existencia de fincas, mientras que la siembra excesiva de árboles en las zonas productivas de las fincas destruye estas unidades territoriales y genera la extensión de formas espaciales como la montaña. El asunto adquiere complejidad en tanto son, además, los límites de propiedad los que permiten determinar la existencia de una finca. En este sentido, una persona, en relación con la siembra de árboles, comentaba:

\begin{abstract}
Porque como siembran y siembran y siembran árboles en todas las tierras que le pertenecieron a don Hendrik. Entonces con el tiempo eso se vuelve es bosques. Y entonces ahí sí qué, quién va a decir "esto es mío o esto es", porque entonces eso ya vienen es y ven la montaña y los estudios que quieren hacer. Y ya los dueños ni vendrán por ahí porque ya en montaña qué. (Entrevista a vecina del sector, 2 de septiembre de 2012)
\end{abstract}

La propiedad de una finca se puede determinar por su delimitación y diferenciación con el paisaje boscoso, es decir, la montaña. La finca es un espacio que tiene propietario, que se diferencia del resto del paisaje, pues sus dueños se encargan de trabajarlo (permitir y fomentar el crecimiento de pasturas y cultivos) y protegerlo de la invasión de la montaña. Pero 
existen visiones contrapuestas en este sentido. Precisamente, los estudios en ecología política cuestionan las percepciones analíticas que enfatizan la homogeneidad de las comunidades y sus formas de apropiación del entorno (Burbano, 2005; Li, 2002; Wittmayer y Büscher, 2010). A la pregunta sobre la importancia y utilidad de la siembra de árboles, esto respondió un vecino cuya familia se dedica a la ganadería:

Pues claro [es importante sembrar árboles] porque hay agua, hay sombra... mejor dicho se ve una finca muy bonita con matas. (Entrevista a poblador local, 15 de diciembre de 2012. Cursivas del autor)

Esta opinión ayuda a reforzar la existencia de dos formas de naturaleza, una más cercana e, incluso, perteneciente a los límites de la finca (monte), y una más lejana y que impide su existencia (montaña). Esta opinión puede servir para replantear la visión de la finca solamente como un lugar productivo o propio de la civilización de la naturaleza reconstruida en los textos de Del Cairo (1998) y que también señala Ruiz (2010). Esto sugiere que entre la finca y la reserva, como dos espacios aparentemente contrapuestos, puede haber algún tipo de correspondencia a partir de la categoría "monte". Los límites entre ambos espacios son difusos, pues muchos consideran la existencia de fincas al interior de la reserva o la existencia de fincas con árboles, lo que genera una fusión de estos dos espacios (finca y monte).

Ruiz (2010) describe cómo los campesinos con los que trabajó en la Sierra de la Macarena a finales de la década de 
1990 y comienzos de la del 2000 conciben la selva como la antítesis del trabajo, en contraste con pasturas, patios y sementeras que dan origen a la finca. Estoy de acuerdo, en buena medida, con este argumento y en Pueblo Viejo los pobladores también protegen sus fincas de la invasión de ciertas especies animales y vegetales para poder resguardar las actividades productivas. Evitan que el retamo espinoso (Ulex europaeus) y otras especies invadan su lote, porque, de lo contrario, el pasto deja de crecer y se pierde la capacidad productiva del terreno. Pero, contrario a este argumento de la finca como antítesis de la selva o el monte, ¿cómo es que se puede considerar a los árboles sembrados en la RBE como parte de una finca? Allí reposa una representación de la finca como terreno que requiere del monte no solo para existir en términos relacionales como contraste entre el interior (finca) y el exterior (monte), sino como una unión de ambos espacios.

La finca tiene bosque, de allí se saca leña para consumo doméstico y el agua, por lo que no se convierten en espacios del todo contrapuestos. En una disputa por linderos en Pueblo Viejo, se constató que una de las familias pedía que se le dejara dentro de su lote una parte de monte, pues aseguraba que este le servía para sacar la leña. Esto muestra que el monte puede ser parte de la finca en tanto permite su existencia simbólica, productiva y de subsistencia.

Los campesinos de Pueblo Viejo conocen la importancia del monte para la proliferación del agua y la protección de los terrenos frente a la erosión. Con todo, la situación de propiedad es clave para determinar si un monte hace parte o no de 
la finca. Si está dentro de los linderos de la finca, hace parte de ella. Esto quiere decir que el monte conforma la finca siempre y cuando se encuentre dentro de sus linderos y tenga usos para subsistencia como la extracción de combustibles o recursos acuíferos. Como lo sugiere la definición de monte que se ha presentado líneas atrás, este es una naturaleza más cercana a las vivencias diarias de las personas y útil para su subsistencia. Ello sugiere que el monte y la finca se difuminan, es decir, dejan de ser espacios contrapuestos. En consecuencia, la antítesis de la finca es la montaña y no el monte. Así, espacios naturales y culturales se convierten en uno solo, lo que permite cuestionar la dicotomía naturaleza-cultura.

Las condiciones históricas aunadas al régimen de propiedad de los predios de la RBE son otro factor que permite que su monte sea entendido como una finca. A diferencia de las zonas de colonización que describen Ruiz (2010) y Del Cairo (1998), para La Macarena y el Guaviare, respectivamente, este lugar está enclavado en la cordillera Oriental en una zona ocupada desde hace más de cien años y donde no existen baldíos. A pesar de la existencia de bosque, el régimen de propiedad que pesa sobre él, en especial el de la reserva que fue poseído por la familia Hoeck, hace que este espacio sea delimitado y quepa dentro de la categoría de finca. De modo que la existencia de un dueño y un pasado como finca hace difícil para los pobladores de estos predios imaginarlos de manera distinta. Otra característica de la finca es su condición de lugar, donde se produce y ejerce una identidad campesina: 
El uso que le están dando a los potreros ahí, creo que pa' la reserva sea favorable, pero pa'l agricultor, pa'l campesino, pues no porque no nos dejaron dónde mantener ganado. Pueda que para ellos sí por los visitantes porque atrae todas las visitas para sembrar árboles, para la fauna, para todo. Pues eso es bien. Pero lo que le digo, si se hace una cosa, no se puede hacer la otra. Si se tiene ganado, no se siembra árboles. Por decir algo, si yo tengo un lote, yo tengo un lote, siembro árboles por la orilla de las quebradas, siembro árboles por la cabecera del potrero, pero nunca en la mitad, nunca eso. (Entrevista a pequeño ganadero local, 3 de septiembre de 2012. Cursivas del autor)

Las frases en cursiva son de suma importancia para entender parte de las representaciones del territorio y la producción de una identidad campesina a partir de ciertas formas del lugar y uso de la tierra. Este habitante, en conjunción con lo que se ha venido sosteniendo frente a la extensión de la montaña en la RBE a partir de la siembra de árboles, permite pensar que lo benéfico para el campesino, el agricultor, no es la siembra de árboles en zonas productivas de los potreros, sino su uso para actividades agropecuarias. Parte de su autoidentificación como campesinos depende de este territorio constituido por pastos y tierras productivas, en este caso, para actividades ganaderas. Pero no solo se trata de la constitución del territorio, sino del uso que se le da, lo que caracteriza parte de la autodefinición campesina, según las observaciones y entrevistas hechas durante el trabajo de campo. Se trata de la apropiación del territorio como espacio 
(en el cual se desarrollan cierto tipo de actividades) en donde se produce y ejerce la identidad (Escobar, 2005).

$\mathrm{Su}$ identificación como campesinos tiene que ver con ciertas formas espaciales como la finca, lugar productivo en donde se practican ciertas actividades como la siembra de cultivos, la extracción de leña y el pastoreo de animales. Esto ha sido analizado por autores como Del Cairo (1998) y Ruiz (2010), en cuyas investigaciones han mostrado cómo para los campesinos colonos, este lugar es un espacio propio de lo campesino en tanto se relaciona con unas formas de vida que civilizan el monte y lo convierten en zonas productivas denominadas fincas.

En campo se constató que esta identificación campesina tiene que ver con ciertas prácticas y formas de entender el lugar de habitación, a diferencia de la montaña y la siembra de árboles en las pasturas de las fincas que imposibilitan la generación de medios de subsistencia, en especial los agropecuarios, y la existencia misma de la finca. Las acciones de restauración ecológica y de ecoturismo ${ }^{7}$ afectan las actividades consideradas como campesinas, debido a que el uso de los recursos naturales se asocia a unas formas de ser particulares. Es claro que en Guasca la introducción de usos conservacionistas por parte de la FNC por medio de la creación de la RBE, y los procesos de restauración ecológica que allí se desarrollan, puede llegar a traer cambios en las formas

$7 \quad$ En el capítulo II se analiza cómo las prácticas ecoturísticas crean nuevas formas de sujeto, o por lo menos pretenden hacerlo, a partir de la figura del ecoguía propuesta en Guasca. 
de vida locales, trasformando sus actividades de subsistencia históricas, que para estos habitantes locales son parte de su cotidianidad, tanto en pensamiento como en sus prácticas.

Siguiendo el enfoque de la Nueva Ruralidad, la apropiación de recursos naturales de la finca - pasturas, agua, tierra, leña-, que efectúan los habitantes de Pueblo Viejo, hace parte de una forma de apropiación espacial, en donde el territorio se torna en categoría clave para entender el campo de forma integral en sus diferentes facetas productivas y sociales (Echeverri y Ribero, 2002). Evidentemente, esto supone un ejercicio de apropiación de un espacio físico a partir del desarrollo de ciertas actividades agropecuarias, entendidas por los habitantes de Guasca como propias de lo campesino. Entonces bien, hay una relación entre uso y valoración de ciertos usos de los recursos naturales y apropiación y construcción territorial. En términos de las actividades que allí se desarrollan, la finca es un espacio y la reserva otro, pues en ambas, hasta cierto punto, se ejercen prácticas distintas.

\section{Comunidades locales y manejo de recursos naturales}

En Guasca, los paradigmas de la conservación ambiental han penetrado de forma más frontal con la constitución de la RBE. En este municipio, los procesos de conservación ambiental se encuentran en una etapa en la que, si bien no se excluye a la población de la habitación del área protegida o sus alrededores, aún hace falta su inclusión en el plan de manejo de la RBE. Las posturas sobre los mecanismos de conservación ambiental a nivel global han tenido dos grandes tendencias: 
los paradigmas de conservación sin gente y los modelos que incluyen a las poblaciones locales que circundan o habitan dentro de áreas de protección ambiental en el cuidado y manejo de sus recursos naturales.

La primera tendencia se remonta a los años cincuenta del siglo xx como principal estrategia de conservación ambiental que proponía separar a la gente de la naturaleza, excluyendo a los humanos y prohibiendo sus derechos de uso, ocupación y consumo de recursos naturales en áreas protegidas (Büscher y Dietz, 2005; Rummenhoeller, 1995). Uno de los antecedentes más reconocidos de este modelo de conservación ambiental fue la creación del Parque Nacional Yellowstone en EE. UU. en 1872 que definió el concepto de parque nacional y su vocación conservacionista excluyente (Rummenhoeller, 1995). El otro modelo surge como paradigma dominante en la década de 1970, pues se demostró, en buena medida, que la conservación excluyente era ineficaz porque pese a ella, la disminución de especies y el deterioro ambiental continuaban (Büscher y Dietz, 2005). Además, se cuestionó lo contraproducente y negativo que resultaba la exclusión de las poblaciones del aprovechamiento y manejo de los recursos naturales en los que basaban sus modos de vida (Büscher y Dietz, 2005; Roe et al., 2009).

En esta medida, en Guasca se desarrolla un doble proceso: a la vez que se permite la habitación de la población, en parte por su condición de propietarios, pero también por un cambio en el paradigma conservacioncita frente a la ocupación humana, se les excluye en la toma de decisiones sobre el manejo del área protegida. Esta situación tiene que ver con que la inclusión o exclusión de las personas en el 
uso, aprovechamiento y manejo de recursos naturales y áreas protegidas está acompañada de una serie de presupuestos. El conservacionismo excluyente plantea que las poblaciones locales no están en capacidad de proteger y usar adecuadamente estos recursos ecológicos, como en parte sucede en Guasca, pues los administradores del área protegida consideran que la población local no ejerce un adecuado uso de los recursos naturales.

Por otra parte, la inclusión de la población encuentra eco en uno de los mayormente conocidos modelos de conservación ambiental, a saber, el CBNRM. Este modelo presupone una vocación de los pobladores locales al uso sustentable; un interés de estas personas por conservar; la existencia de una comunidad homogénea y colectiva que usa los recursos naturales de forma horizontal y comunitaria; la existencia de unos usos, conocimientos y prácticas tradicionales sustentables, y la dependencia de estas comunidades de los recursos protegidos (Tsing, Brosius y Zerner, 2005; Büscher y Dietz, 2005; Roe et al., 2009; Rummenhoeller, 1995; Agrawal, 2001; Li, 2002; Wittmayer y Büscher, 2010). Sin embargo, este modelo y sus planteamientos están ausentes en el caso de la RBE, pues los funcionarios de la FNC no consideran que los pobladores estén en la capacidad de usar adecuadamente los recursos, como en varias ocasiones se constató en conversaciones con el jefe de la RBE, quien se refería al uso inadecuado del agua u otros recursos naturales que ejercía la población local. Más bien se propone modificar sus prácticas en pro de fomentar la conservación ambiental y el uso sustentable de los recursos naturales. 
Como lo proponen Tsing et al. (2005), el CBNRm puede ser una forma de acortar costos en los procesos de cuidado ambiental para los estados. De tal suerte que la situación de Guasca tiene algunos aspectos relacionados con este modelo en la medida en que se han descentralizado funciones estatales de manejo ambiental delegadas en terceros, en este caso en actores de la sociedad civil, como la FNC (si bien no en la población local). En suma, la existencia de una reserva privada de la sociedad civil en Guasca tiene que ver con la descentralización del ejercicio de Gobierno, propia del neoliberalismo, que ha generado que el estado ceda parte del gobierno sobre el ambiente (Agrawal y Lemus, 2007). Las políticas promovidas y diseñadas por el Banco Mundial y el Fondo Monetario Internacional han propuesto que el estado nacional es ineficiente y costoso. La respuesta a esta situación ha consistido en que el sector privado se haga cargo del manejo de ciertas tareas que antes competían exclusivamente a las instituciones, en este caso frente al manejo ambiental. En Guasca, se descentralizan estas funciones de la autoridad ambiental (Corporación Autónoma Regional del Guavio [Corpoguavio]), y las empiezan a ejercer sujetos privados como la FNC. Esto se hace evidente en un documento inédito de planeación de la RBE, elaborado por la FNC:

Para esta institución [Corpoguavio] la Reserva permite el cumplimiento de sus objetivos y su misión, pues es su deber promover el establecimiento de áreas protegidas, entre ellas las Reservas de la Sociedad Civil. (Fundación Natura Colombia [FNC], s. f.) 
Este modelo neoliberal de reducción del aparato estatal a partir de la descentralización y privatización de algunas de sus funciones constituye una forma de gobernanza en la que el gobierno es ejercido tanto por las instituciones como por diversos actores sociales. En Guasca, como parte de este modelo de gobernanza, a la vez que se descentraliza el manejo ambiental del estado, se concentra en algunos otros actores. El concepto de gobernanza asume que el gobierno no es un ejercicio solo del estado, sino que depende de la interacción entre actores involucrados que permiten construir tal control (Franky y Mahecha, 2010). Este concepto tiene que ver con la participación política de todos los sujetos involucrados en la toma de decisiones y el considerar que las personas no asumen de forma pasiva las políticas, sino que participan activamente en los ejercicios de gobierno (Durán, 2009; Franky y Mahecha, 2010).

Pese a que existe una descentralización del manejo ambiental y de las funciones de gobierno por cuenta de la gobernanza, en Guasca este proceso es asimétrico entre los diferentes actores de la sociedad civil. Esta, en su conjunto, entra en la dinámica de manejo ecológico, pero a la vez unos actores de este conglomerado civil (FNC) toman mayor poder de decisión que otros (población local) sobre el manejo ambiental.

En Guasca, los procesos de manejo ambiental descentrados del estado, por cuenta del neoliberalismo, producen procesos participativos de algunos actores sociales (FNC) al tiempo que generan desigualdades e imposibilitan el accionar de otros (población local). En suma, el problema de las 
formas neoliberales de conservación ambiental, como las presentes en Guasca, es que constituyen formas de privatización del manejo ambiental, más que de democratización, pues terminan siendo los actores con mayor poder y capital los que toman las decisiones y no la población civil en su conjunto.

El ejercicio de descentralización del poder sobre las decisiones ambientales, que supone el concepto de gobernanza, no necesariamente está acorde con los intereses y las realidades de la población de Pueblo Viejo, en especial porque ciertos actores de la sociedad civil gozan de mayor poder dentro de la descentralización. El proceso que se está dando en Guasca es una descentralización asimétrica del poder, a partir del fomento de la gobernanza. La participación de la población se ve menguada y restringida porque las "reglas del juego" son impuestas por la FNC, y los habitantes locales para participar deben entrar en las lógicas establecidas de antemano.

Un problema de este modelo de descentralización de las funciones de gobierno en el cuidado ambiental radica en que la participación de las poblaciones locales depende, en buena medida, de la voluntad estatal o los que hacen sus veces, como la FNC. Un ejemplo al respecto es el trabajo de Durán (2009) para el caso del Parque Nacional Natural Corales del Rosario y San Bernardo, en donde la aplicación de una descentralización del manejo ambiental dependió de la promulgación de leyes que reglamentaran la participación de las poblaciones étnicas en la toma de decisiones. 
Esta ha sido precisamente una de las principales críticas a los modelos de gobernanza ambiental, entre ellos el СвNRM, puesto que el poder que ejercen las poblaciones locales sobre el ambiente no depende de su legítimo papel por ser habitantes del lugar, sino que emana del mismo estado, o incluso el modelo mismo se convierte en una forma de despojo, control y dominio sobre los actores locales. Esto disminuye su autonomía y subordina a las poblaciones al poder estatal o a las organizaciones no gubernamentales (ONG) (Tsing et al., 2005; Roe et al., 2009). En la RBE, las personas puede acceder a la toma de decisiones bajo la voluntad de la FNC y no por su condición de habitantes de antaño.

A nivel nacional, los paradigmas de conservación, que tienen lugar en Guasca, según las características anteriormente descritas, poseen un desarrollo particular. En Colombia, la política de manejo ambiental, en especial en áreas protegidas, dio un giro, por lo menos en el discurso, de conservación excluyente a incluyente hacia los años noventa. Dos factores toman lugar en este proceso: las políticas multiculturales y la descentralización estatal aunada en las políticas neoliberales. El caso del Parque Nacional Natural Corales del Rosario y San Bernardo es claro al respecto. En su creación, en el año 1977, se estableció una política de conservación sin gente, que hacia los años noventa tuvo un cambio sustancial porque la población local, debido a las políticas de participación, a la Ley 70 de 1993 y a la Constitución de 1991, se organizó y reclamó sus derechos y territorios (Durán, 2009). Este caso ejemplifica, en buena medida, la situación nacional en cuanto al manejo ambiental comunitario. El asunto del 
manejo de recursos naturales en el país, entonces, se tornó complejo porque se cruzaron variables étnicas y ambientales. Esto tiene que ver con que el modelo CBNRM privilegia a la población indígena como base para su aplicación (Li, 2002). A partir del establecimiento de unas políticas multiculturales en el país, la participación de los grupos reconocidos como étnicos aumentó, entre otras razones, por la organización política, el reconocimiento territorial y la consulta previa que el multiculturalismo impuso en relación con estas comunidades, lo cual les posibilitó ser parte de los procesos de gobernanza ambiental.

Una particularidad de Colombia es la superposición de territorios de los grupos étnicos y áreas protegidas, y la presencia de población en los parques nacionales (Rummenhoeller, 1995; Ulloa, 2004). Debido a la superposición de áreas protegidas con lugares de habitación de diferentes poblaciones, ha habido conflictos constantes entre las autoridades ambientales y la población por cuenta del uso, la propiedad y la ocupación de áreas de conservación ambiental. No obstante, las políticas de participación de grupos étnicos han favorecido los mecanismos de intervención de algunas de estas comunidades en el manejo de las áreas protegidas.

Planes de la Unión Internacional para la Conservación de la Naturaleza (UICN) y otras organizaciones ambientales internacionales en 1991 atribuyeron un papel especial a los pueblos indígenas y locales en los esfuerzos de conservación global (Rummenhoeller, 1995). Otro dictamen clave fue el Convenio 169 de la Organización Internacional del Trabajo (ОIт) que proclamó, entre otros, la participación de estas 
comunidades en la toma de decisiones que les afectan. Por su parte, el Congreso Latinoamericano de Parques Nacionales y otras Áreas Protegidas en 1997 (celebrado en Santa Marta) definió que el manejo y la planificación de estas zonas deben hacerse con la participación de comunidades ocupantes o aledañas (Luque y Valenzuela, 2001).

Este tipo de discusiones y acuerdos internacionales impactaron en la política nacional. Hacia los años noventa el panorama participativo en el manejo de las áreas protegidas cambia, en buena medida, por cuenta de la descentralización estatal que definieron las nuevas políticas neoliberales aplicadas en el país con mayor vigor en esta década, el fomento de la participación, la defensa de los derechos colectivos, la responsabilidad social por la protección ambiental y la veeduría ciudadana promovidos por la Constitución Política de 1991 (Ulloa, 2004). Así, surge una nueva forma de administración de los parques nacionales naturales denominada "Parques con la gente".

El enfoque de "Parques con la gente" de la Unidad Administrativa Especial del Sistema de Parques Nacionales Naturales (UAESPNN) tiene que ver con la inclusión de las poblaciones locales, en especial indígenas y afrocolombianas, en el manejo de áreas protegidas, debido a su reconocimiento cultural (Ulloa, 2004). En este contexto de inclusión de la población local en las áreas protegidas públicas y las políticas oficiales, la situación de las áreas privadas es aún más compleja. Los administradores de la RBE son sujetos privados que si bien se acogen a la ley, pueden dictar los mecanismos de manejo del área y no necesariamente están en la obligación 
de incluir a la población, en especial porque su área protegida es privada. Esto sugiere que si bien la política nacional ha dado pasos hacia la inclusión de las poblaciones, aún queda mucho por hacer a nivel de la práctica y más si consideramos que no solo el estado se encarga de administrar áreas protegidas.

En consecuencia, pese a estas retóricas de "Parques con la gente" y la popularidad de la conservación basada en comunidades, existen casos como el del Tayrona en los que la gente sigue siendo vista como ecoamenazas (Ojeda, 2012. Gonzáles, 2014), o el de la RBE, en que sus administradores no ven en las poblaciones una capacidad de aporte per se a la conservación ambiental, sino más bien de manejo inadecuado de los recursos naturales.

Sin embargo, no deja de haber un desbalance también entre las políticas oficiales y su aplicación por entidades estatales, incluida la UAESPNN, como lo muestran Rodríguez y Sguerra (2001), pues si bien reconocen la participación de otros grupos afectados por la constitución de áreas protegidas, sostienen que para el caso del Parque Nacional Natural Utría, se estableció quiénes debían participar en el manejo del área protegida, a saber, comunidades indígenas amparadas internacionalmente y las comunidades negras. En este sentido, hace falta una denominación campesina para los sujetos a participar. Pese al reconocimiento de la participación de todas las comunidades afectadas, hay un sesgo etnicista (o de las etnicidades reconocidas) frente a la determinación de quiénes deben ser incluidos en la concertación del plan de manejo. 
Como se ha sostenido, los campesinos de Guasca poseen motivaciones e intereses frente a su territorio y la naturaleza no solo de carácter económico, sino también frente a su apropiación y significación que entran en tensión con la conservación propuesta en la RBE y que son ignoradas para el establecimiento de planes de manejo en conjunto de la reserva. Como se mencionó, la falta de referentes claros sobre la participación e inclusión de los campesinos en la toma de decisiones sobre las áreas protegidas imposibilita su capacidad de acción directa en el manejo incluyente de las zonas de conservación ecológica. Esto ha supuesto una desventaja para este grupo poblacional, debido a que en el imaginario estas personas han sido vistas como ecoamenazas y sujetos sin cultura, por causa de su marcación no étnica como mestizos, lo que contribuye a pensar que carecen de prácticas y requerimientos multiculturales verdes que les otorguen disposición inherente para la conservación (Ojeda, 2012).

En Guasca se pudo observar cómo estos imaginarios operan, pues la alusión que hacían los funcionarios de la FNC sobre la población local no involucraba aspectos simbólicos de su relación con la naturaleza, o de la apropiación del espacio, sino ideas que giraban en torno a la producción económica y el cambio de sus prácticas de uso de los recursos naturales, como el agua. El jefe de la RBE nunca mencionaba una predilección por el cuidado ambiental de los vecinos de Pueblo Viejo o su relación histórica con el espacio y la naturaleza, sino una necesidad de modificar sus prácticas y fomentar, como él lo decía, un "cambio cultural” en pro de la sostenibilidad. 
En este municipio existe un desbalance entre las políticas estatales y las realidades locales en cuanto a la discusión del plan de manejo y la gestión de la RBE. Si bien algunas políticas públicas, como las que se han venido reconstruyendo, proponen la inclusión de las poblaciones locales, la FNC establece un manejo de la RBE desligado de una discusión y concertación con los pobladores. Parte de esta exclusión se hace evidente en un acta de una reunión entre los representantes de la FNC y los donadores de los predios donde está ubicada la RBE, llevada a cabo en mayo de 2005, en donde se discuten varios temas, entre ellos la posible estructura de manejo del área protegida. Dentro de esta estructura, mencionan a un representante de la familia Hoeck, un representante de la FNC, una universidad, otra fundación ambiental interesada y la Red de Reservas de la Sociedad Civil. Posteriormente, se menciona que estas entidades tomarán decisiones referentes a la zonificación, el plan de manejo (uso de los recursos), aprobar balances y recoger fondos (Fundación Natura Colombia, 2005, pp. 1-2). En consecuencia, desde la planeación de esta área protegida, la toma de decisiones clave sobre la RBE y la conformación de su escultura de manejo desconocen de antemano la participación de los actores locales.

En una publicación de la UAEspnn, denominada Parques con la gente. Política de participación social en la conservación. Avance 1998-2000, se hacen algunas consideraciones sobre las formas de manejo de recursos del ambiente y áreas protegidas con comunidades locales. Establecen que "Parques con la gente" es una forma de denominar a la política de participación social en la conservación que pretende la 
protección de ecosistemas estratégicos y el patrimonio cultural y natural de la nación (Unidad Administrativa Especial Sistema de Parques Nacionales Naturales [UAESPNN], 2001). En esta definición de la política, existe una clara articulación entre conservación ambiental y conservación cultural, que ya se ha discutido en este texto. Más adelante agregan que:

El plan de manejo es inherente a la planificación de cada parque nacional natural. Se concibe como un lugar de encuentro entre diferentes intereses o expectativas sociales, sistemas de regulación, competencias y jurisdicciones institucionales, que se traslapan para que la función de protección y autoridad sobre los ambientes naturales sea legítimamente instituida desde todas las miradas que conforman el territorio de uso y ocupación por parte de las comunidades humanas. Todas las líneas estratégicas confluyen en la construcción participativa del plan de manejo. (UAESPNN, 2001, pp. 17-18)

Surgen categorías centrales en esta cita que son fundamentales para pensar el manejo de recursos naturales participativo en Colombia. Plan de manejo es una de ellas, lo cual hace alusión a la hoja de ruta que guía el uso y la vocación de las áreas protegidas. Lo interesante es que resalta la importancia de la construcción de este plan en conjunto con las poblaciones locales y de acuerdo con los intereses de los diversos actores involucrados. Además, reconoce la existencia de la ocupación y uso del territorio por parte de grupos humanos no desde una mirada negativa, sino como 
elementos a tener en cuenta en la conformación del plan de manejo. Tal como está plasmado este argumento deja ver que el plan de manejo es fruto de un proceso de negociación entre las partes, más que una imposición.

Sin embargo, en Guasca no se reconoce de forma directa la ocupación, el uso de los recursos naturales y la participación local en la construcción del plan de manejo como elementos positivos per se para el área protegida, lo cual contrasta con otros casos a nivel nacional. En el volumen de Parques con la gente Zárate y González (2001) exponen el caso de la región de La Macarena en donde los campesinos se organizaron para proteger los recursos naturales, firmaron acuerdos e hicieron procesos de concertación y capacitación con las autoridades ambientales para la elaboración del plan de manejo de los bienes ambientales por medio de una zona de reserva campesina. Esta figura propende por la articulación de la sostenibilidad ambiental, social y económica; el control de la colonización; la implementación de medios de producción acordes con el medio; el ordenamiento territorial; planes de desarrollo concertados, y redistribución de la tierra, incluida la de algunos parques nacionales (Fajardo y Sepúlveda, 1995; González y Múnera, 1998). Con esta figura se da un giro hacia la inclusión de la población campesina en el manejo ambiental, aunque aún bajo el desconocimiento de sus relaciones culturales con el territorio y la naturaleza. Sin embargo, esta propuesta no ha tenido mayor alcance en el país.

Lo que más llama la atención del texto de Zárate y González (2001) es que estos autores, como funcionarios de 
la Unidad Administrativa de Parques Naturales y del Ministerio de Medio Ambiente, respectivamente, sostienen que los colonos reproducen las prácticas culturales de ocupación del territorio propio de sus regiones de origen. Con ello reconocen que los campesinos tienen unas formas de relación con el ambiente mediadas por elementos culturales, y no solo materiales, muy ausentes en los planes de manejo que involucran a este tipo de población.

Tal propuesta supone, en buena medida, un cambio en la visión del campesino hacia formas de inclusión no solo como actores presentes, sino como clave en la proposición de planes de manejo a partir de unos conocimientos particulares del entorno y unas formas de producción, aún ausentes para el caso de Guasca. Allí los administradores del área protegida todavía no se han preocupado por conocer e indagar sobre los saberes locales y su potencial para un manejo participativo de la RBE. Pese a que la descentralización abrió caminos en la veeduría ciudadana sobre el manejo ambiental y de diálogo y negociación entre las organizaciones de la sociedad civil y las comunidades (Londoño, 2008), en Guasca estos procesos están aún por construirse.

Pero la participación en el manejo ambiental que se ha discutido hasta el momento tiene que ver con territorios públicos, en particular con parques nacionales y áreas de manejo especial declaradas y manejadas por el estado. No obstante, las formas en que el estado ha cedido el gobierno sobre el ambiente, en un proceso que se denominó gobernanza según las propuestas de Durán (2009), Agrawal y Lemos (2007) y Franky y Mahecha (2010), en la que el poder se ha 
descentralizado por cuenta del neoliberalismo y las políticas de participación ciudadana, implican la emergencia de áreas protegidas privadas como la de Guasca. En lo que respecta al manejo ambiental, algunos actores organizados en ONG han participado en la administración de los recursos naturales, como sucede en Guasca en donde la RBE es dirigida por una ONG.

Estos caminos de participación abrieron la posibilidad a que ciertas organizaciones crearan reservas privadas de la sociedad civil, que pueden pertenecer al Sistema Nacional de Áreas Protegidas (SINAP) como áreas privadas, toda vez que sean registradas por sus propietarios (Ministerio de Ambiente, Vivienda y Desarrollo Territorial, 2010). Esto permitió la existencia de la RBE como propiedad privada declarada voluntariamente como área protegida y registrada como tal por sus propietarios para cumplir una función pública, a saber, la conservación ambiental, de la mano del sinap del estado colombiano.

En estas áreas protegidas las organizaciones y los miembros de la sociedad civil ejercen funciones del estado porque están en la obligación y la capacidad de dictaminar las formas de manejo de los recursos naturales y de constituir áreas protegidas, según lo establecido en la ley. Tal forma de gobernanza ambiental es sumamente compleja porque las organizaciones, en este caso la FNC, proponen usos en suelos privados que tienen afectaciones de carácter público. La declaratoria de un área protegida por parte de la FNC implica que esta organización, como miembro de la sociedad civil que la posee, proponga y restrinja ciertos usos y accesos 
sobre predios, lo que altera las dinámicas locales de apropiación territorial, uso de recursos naturales y trabajo. La complejidad a la que se hace referencia es que actores privados tienen el dominio sobre porciones de tierra declaradas como protegidas y la ley no establece con claridad, para las reservas privadas de la sociedad civil, unos mecanismos de participación, negociación y concertación con la población, pues se asume que por el hecho de ser los ciudadanos los que declaran el área, hay una participación efectiva.

En el caso de Guasca, esto no resulta cierto, en especial porque la declaratoria del área protegida proviene de afuera y no de la población. La descentralización neoliberal, por consiguiente, produce formas espaciales como áreas protegidas privadas en las que hace falta regulaciones claras sobre los mecanismos de participación y las obligaciones frente a las poblaciones locales de estas zonas de conservación ecológica de la sociedad civil.

Para finalizar, se hará una recapitulación de lo abordado en este apartado. Se discutieron las formas de análisis de la relación cultura-naturaleza en las ciencias sociales, con énfasis particular en la antropología y a la luz de los hallazgos en campo, con el fin de cuestionar la dicotomía que separa la cultura de la naturaleza; se propone que estas categorías se interrelacionan y coproducen.

El interés en la primera sección del capítulo fue abogar por una crítica a las formas economicistas a partir de las cuales se ha pensado a los campesinos en los estudios rurales clásicos y en las políticas oficiales, desconociendo sus relaciones históricas y cotidianas con el territorio y sus 
representaciones del entorno. Ha habido una "economización” excesiva de los campesinos como sujetos racionales, productivos y tendientes al progreso material en ausencia de cultura. Si bien la teoría de los estudios rurales ha dado avances significativos en la deconstrucción de la dicotomía campesino-indígena, en el reconocimiento étnico colombiano imperan imágenes de campesinos e indígenas por separado no solo en cuanto a su reconocimiento, sino a su “aislamiento político" (Bocarejo, 2011, p. 97).

La díada indígena-campesino, creada por el multiculturalismo y que divide a estos dos grupos en dos categorías que los asilan políticamente y les asignan propensiones a ciertas prácticas - productivas para los campesinos y de cuidado ambiental para los indígenas-, es una dicotomía que es necesario deconstruir (Graham y Gibson, 2002).

Por otra parte, en la segunda sección de este capítulo se propuso una discusión sobre las formas en las que se ha entendido la participación de poblaciones locales en el manejo de recursos naturales en las políticas de conservación y sus implicaciones y particularidades para el caso de Guasca. Se discutió, de igual manera, cómo las imágenes de los campesinos y sujetos étnicos irrumpen en los escenarios de participación posibilitándola o imposibilitándola. Además, se vislumbró cómo estas ideas de la participación en la toma de decisiones ambientales como la consulta previa y la formulación de planes de manejo presentes en las políticas ambientales de la UAESPNN crean sujetos ambientales y ambientes particulares bajo ideas que encasillan las identidades y relaciones de los grupos sociales. 
La participación de los actores involucrados y afectados por cuenta de un área protegida es fundamental y debe ser independiente de sus condiciones de género, clase, etnicidad, raza y edad. Esta se hace necesaria para fomentar modelos de inclusión efectiva que, si bien tienen implicaciones en el papel del estado (privatización), permiten que los actores sociales tengan herramientas para manejar sus territorios y recursos ambientales. Finalmente, este modelo de gobernanza, relacionado con la descentralización estatal y la producción de zonas de protección ecológica privadas, delega a la sociedad civil y sus organizaciones parte de su función de administración del ambiente, lo que supone lógicas de privatización de la naturaleza que afectan a las poblaciones locales, toda vez que no existen mecanismos claros para su intervención en las áreas protegidas privadas. 



\section{Capítulo II \\ El trabajo en Pueblo Viejo: conservación ambiental y oportunidades laborales}

$\mathrm{Al}$ iniciar este trabajo y conocer a los vecinos del sector, aún no se había definido con claridad el problema de investigación. Pronto, a partir de las conversaciones con los habitantes del sector de Pueblo Viejo, se identificó que uno de los principales cambios que había sufrido la localidad, desde la época de la mina, había sido con respecto a la oferta de trabajo. Esta trasformación no solo tiene que ver con el cierre de la mina, sino con la constitución de la RBE en el año 2007. De allí se derivó parte del interés por indagar sobre las problemáticas de la constitución de áreas de conservación ambiental para los pobladores locales, en particular, las tensiones a nivel laboral.

En la primera parte de este capítulo se analizarán las razones de la añoranza de los pobladores locales por la época en que operaba la mina a nivel laboral y se caracterizará parte de la situación actual de trabajo en el sector. Posteriormente, en la segunda sección de este apartado, se analizarán las tensiones en torno a la situación de trabajo con respecto a la RBE. 


\section{El trabajo en el sector hoy en día: dificultades y añoranzas}

-Vecina: Pues cuando la mina sí había trabajo, sí eso llegaban de bastantes partes, de Gachalá, de Junín venían gente a trabajar. Y como el doctor Hermann tenía hato, entonces los unos a los hatos y los otros a las minas, y así. Pero ahí vivía la gente y ahí se defendía con el sueldito que ganaba. -Felipe Rojas: Y ahora la situación de trabajo o sea de la cantidad de trabajo que hay acá...

-Vecina: Pues únicamente... [hay] poco trabajo. Ahora sí es poco trabajo porque la mina abastecía a bastantes obreros sí, eso sí y la agricultura también. Ahora sí poco trabajo hay por aquí. Poco trabajo porque como la mina la privatizaron y todo eso, entonces ya murió el doctor Hermann y entonces ya eso se acabó. Sí, señor. Pero sí eso sí abastecía, abastecía bastantes obreros, claro. Eso ya le digo por allá venían de Gachalá, de Junín, venían a trabajar aquí, a la mina. (Entrevista a vecina de Pueblo Viejo, 2 de septiembre de 2012)

La época en que funcionó la mina de piedra caliza es recordada por los habitantes de Pueblo Viejo como un periodo en donde existía una gran cantidad de puestos de trabajo. Si bien los vecinos expresan reparos sobre la mina a nivel ambiental por el daño a fuentes hídricas o la erosión de algunos terrenos, e incluso sobre lo pesado que resultaba el trabajo allí y las afectaciones que traía a la salud de los obreros, en particular en los pulmones por cuenta del polvo 
de la cal, algunos rememoran esos tiempos como un periodo de bonanza en la zona en cuanto a la situación laboral, pues había cantidad y calidad (en cuanto a prestaciones sociales) en el trabajo. Los obreros de la compañía explotadora de cal, empresa que operó la mina por más de sesenta años, contaban con un contrato laboral y prestaciones sociales, y muchos de sus trabajadores lograron pensionarse. Por otro lado, la situación actual de trabajo de Pueblo Viejo no es muy prometedora.

El cierre de la mina en 1992 condujo a esta zona a un declive a nivel laboral que se extiende a la actualidad. Acorde con algunas de las opiniones locales, uno de los principales problemas laborales no consiste propiamente en el desempleo, sino en la falta de ofertas laborales en Pueblo Viejo que permitan a las personas trabajar sin la necesidad de desplazarse por fuera de la vereda. En consecuencia, la necesidad de salir a buscar empleo por fuera de Pueblo Viejo, en buena medida por el vacío que dejó la mina, se constituye en una de las dificultades a nivel laboral que identifican los habitantes locales:

No, aquí no se consigue trabajo. Para trabajar toca salir a trabajar por allá a los pueblos, a la ciudad, [...]. (Entrevista a vecina del sector, 8 de septiembre de 2012).

[...].

Hay mucho desempleo en hombres y mujeres. Mire, por decir algo, esas señoritas, esas señoras acá no tienen empleo. Están consiguiendo trabajo por otros lados, tienen que irse hasta la ciudad, consiguen el empleo, pero entonces salen 
muy tarde en la noche y no pueden regresar a la casa [...]. (Entrevista a vecino del sector, 3 de septiembre de 2012)

La investigación en campo sobre la situación de trabajo en la vereda arrojó los siguientes datos (figura 4).

Figura 4. Tipos de trabajo remunerados en Pueblo Viejo

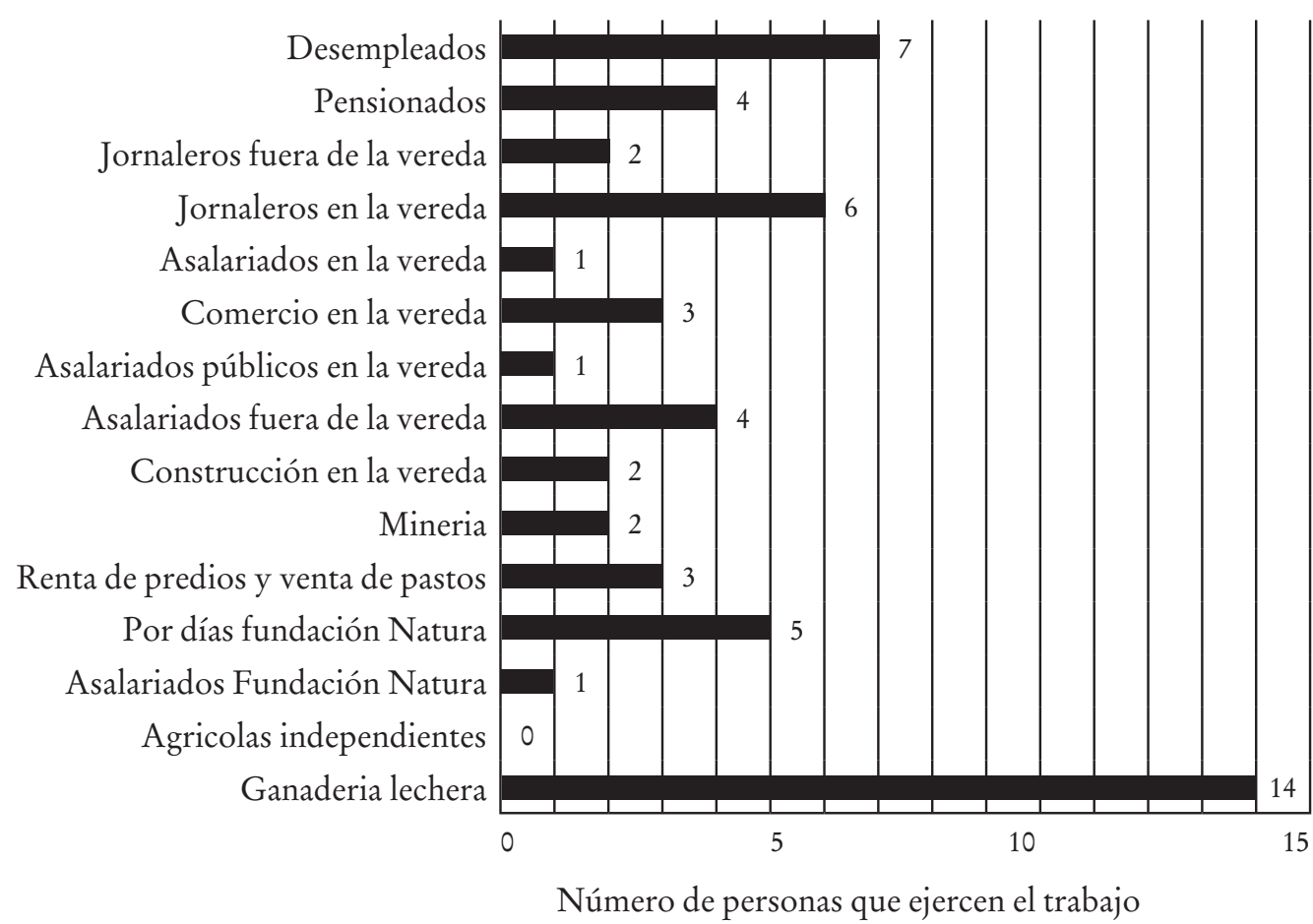

Fuente: elaboración propia.

Estos datos, recolectados por medio de las entrevistas y el trabajo de campo, podrían indicar que la situación laboral de la vereda no es precaria. ${ }^{8}$ Sin embargo, no se trata de una apreciación errada por parte de los pobladores de Pueblo Viejo el sostener que actualmente la situación laboral de

8 Con situación laboral precaria se hace referencia a la falta de ofertas de trabajo, inestabilidad laboral, falta de contratos y deficiencia en la remuneración y las prestaciones. 
la vereda es precaria, más bien refleja la añoranza de unas condiciones laborales pasadas muy favorables en cuanto a "calidad" (prestaciones sociales, contratos laborales, dotaciones, sueldos fijos, entre otros) y cantidad de los empleos, actualmente ausentes en la vereda.

Los vecinos del sector añoran, en cuanto a calidad y cantidad de puestos de trabajo, los últimos veinte años de la mina en donde el sindicato de trabajadores generó el otorgamiento de prestaciones, mejoras en el salario y dotaciones, lo que llevó a que las condiciones laborales de los obreros mejoraran considerablemente. Si bien pareciera que en la relación entre población laboralmente activa y número de trabajos no existe un desfase actualmente en Pueblo Viejo, a nivel de la calidad del empleo, que se define para este caso como estabilidad, contrato laboral y prestaciones sociales, sí hubo una desmejora a partir del cierre de la mina. En ese entonces los trabajadores de la compañía explotadora de cal, calculados a partir de las memorias orales en más de treinta trabajadores, contaban con dotaciones, prestaciones sociales y contrato laboral.

En este sector trabaja una población total de 37 personas. La figura 1 supera este número, pues la discriminación corresponde al tipo de labores, muchas de las cuales son realizadas simultáneamente por una misma persona. Por ejemplo, un jornalero en el sector trabaja en fincas haciendo distintas labores, pero a su vez se dedica a pastorear su propio ganado y vender la leche que este produce. De estas 37 personas que trabajan, 6 se desempeñan por fuera de Pueblo Viejo. Esto sugeriría que no existe ausencia de ofertas laborales en el 
sector, pues solo el 16,2\% de los habitantes locales que trabajan deben buscar empleo por fuera, cifra que a su vez representa el porcentaje de déficit de oferta laboral en la vereda. Sin embargo, la cifra no es desdeñable, en especial si se considera que estos datos tienen como base la población que actualmente reside en el lugar y no la que tuvo que migrar a vivir a otras zonas en busca de empleo.

Este proceso de disminución de la oferta de puestos de trabajo que tuvo lugar en Guasca no solo tiene que ver con el declive de la mina, pues a nivel más general, se relaciona con una precarización de las condiciones laborales del campo, cuya base no es únicamente la expansión de la industria y los servicios y el crecimiento urbano. El proceso expansivo económico que supuso la mina generó un amplio número de fuentes de trabajo y mejora de calidad de vida, mientras que una actividad conservacionista, anclada en procesos de ecoturismo y servicios ambientales, fue una de las causantes de disminución del trabajo local. Sin embargo, la precarización a la que se hará referencia más adelante, en cuanto al trabajo en las grandes fincas aledañas, está relacionada también con los procesos de industrialización y modernización que afectaron la oferta de puestos de trabajo estables y con buenas condiciones en las áreas rurales, y que convirtieron al campo en uno de los sectores con mayor informalidad laboral (Cavalcanti y da Mota, 2003).

Durante el trabajo de campo, se pudo constatar que muchas personas que no viven actualmente en Pueblo Viejo tuvieron que salir de allí en el momento que alcanzaron la edad laboral, debido a la falta de ofertas de empleo. 
Una tendencia en el sector consiste en la salida de los miembros más jóvenes del hogar una vez finalizan sus estudios secundarios. Sus padres se quedan en el lugar, pero los hijos, algunas veces por tener otro tipo de proyectos de vida que no involucran el trabajo en el campo, y en otros casos debido a la falta de empleos, emigran:

-Felipe Rojas: ¿Y por qué por acá no trabajaron [sus hijas]? -Vecina: No, por aquí no había trabajo... Tocaba salir era allá, ir a Bogotá a trabajar. Mi hija, la mayor, ella sí se fue a trabajar, salió de estudio, ella sí hizo todo su bachiller y salió de estudio y ahí sí se fue a trabajar.

-F: ¿Y en qué trabajaron sus hijas?

-V: Trabajaban en casa de familia (refiriéndose a labores vinculadas al servicio doméstico).

-F: ¿En dónde?

-V: Estuvieron trabajando en La Calera. La Natalia9 estuvo trabajando en La Calera, en una casa de familia. La otra también. Todas mejor dicho trabajan en casa de familia... en La Calera y en Bogotá. Y una que estuvo trabajando también fue en Sopó por allá para el lado de Alpina que estuvo trabajando con un primo que estaba trabajando. (Entrevista a habitante del sector, 8 de septiembre de 2012)

$9 \quad$ Nombre cambiado. 
En otra entrevista un vecino comentaba:

Felipe Rojas: ¿Pero actualmente acá las fuentes de empleo, digamos que sí alcanzan a dar abasto para la población o hay gente que le $[\ldots]$ ?

-Vecino: No, de acá se tienen que [ir]. Mucha gente está trabajando por allá en las empresas, en Alpina, en cartones, en las floristerías abajo. Sí, porque a este lado no... ya ocupan en una finca dos, tres personas nada más. (Entrevista a vecino del sector, 20 de agosto de 2012)

Estos fragmentos de entrevista ejemplifican la situación de muchas de las personas que tuvieron que salir del sector por falta de oportunidades laborales. Los mayores se quedaron para no dejar sus propiedades o simplemente porque no sentían que a sus edades encontrarían oportunidades o se adaptarían a modos de vida en el área urbana. De tal suerte que muchos de sus hijos salieron en busca de opciones laborales y educativas acordes con sus proyectos personales de vida, o por causa del déficit laboral, no solo en cuanto a cantidad de trabajo, sino a su calidad.

Parte de la situación laboral adversa se constató, además, en conversaciones con una habitante del sector, quien hacía referencia a las dificultades que afrontaban los trabajadores de dos fincas lecheras de gran extensión del lugar, conocidas en el sector como hatos. Según esta persona, estas fincas no brindan estabilidad laboral a sus trabajadores, pues los despedían constantemente. Esas fincas corresponden a grandes extensiones de tierra con vocación ganadera y agrícola que 
no están supliendo las necesidades laborales del sector; es más, han precarizado el trabajo al pagar bajos salarios y no brindar estabilidad a sus trabajadores.

Esto se relaciona, en una escala más amplia, con las crisis laborales y económicas del sector rural, así como el crecimiento industrial urbano que generaron flujos de migración rural-urbana o rural-rural (Cavalcanti y da Mota, 2003; Flores y de Grammont, 2003). La creciente urbanización en conjuntos cerrados exclusivos que ha tenido el municipio de Guasca y sus alrededores (La Calera y Sopó) ha generado fuentes de empleo en condominios y clubes campestres ubicados en la zona en el servicio doméstico, jardinería, entre otros. Esto ha tenido repercusiones en la migración de personas de las veredas hacia las cabeceras municipales o la tendencia a buscar trabajo fuera de las zonas rurales o las actividades agropecuarias. Teniendo en cuenta la crisis productiva del sector rural, la urbanización ha permitido la oferta de puestos de trabajo en empleos como construcción, servicio doméstico, jardinería, asistencia en deportes, cuidado de niños y mascotas, entre otros.

Se pudo constatar en campo parte de las dificultades laborales rurales en Pueblo Viejo durante el desarrollo de un trabajo con los niños de la IEDC, sede Rodríguez Sierra, ubicada en Pueblo Viejo, junto con la pedagoga Ana María Ramos. En una de las visitas a la escuela, uno de los niños comentó que se iba de la vereda y, ante la pregunta del por qué, dijo que a su mamá la habían "emproblemado" en la finca, acusada de un robo. Agregó: "Felipe, es que a nosotros de todas partes nos sacan". Este tipo de comentarios y las visitas 
a la escuela permitieron apreciar la situación de migración y falta de estabilidad laboral de las familias. En la escuela, el número de alumnos fluctuaba con constancia. Los hijos de aquellos que trabajaban en las dos grandes fincas de Pueblo Viejo llegaban a mediados del año escolar a la escuela y antes de que este finalizara, sus padres o acudientes eran despedidos por sus patrones, u "obligados" a renunciar acusados de administrar inadecuadamente las fincas o efectuar robos. Varios niños llegaban y salían de la escuela porque sus padres debían emigrar del sector y buscar trabajo en otro lugar.

Toda esta situación refleja unas dificultades laborales que no solo corresponden a Pueblo Viejo, sino que también se presentan en otros escenarios rurales. Las familias que llegaban de lugares como Muzo (Boyacá), Bojacá y El Rosal (Cundinamarca), entre otros, y posteriormente emigraban, hacen parte de una dinámica en que las personas pasan de finca en finca, de un trabajo a otro. La modalidad de trabajo consiste en que el dueño de la tierra los deja vivir en el predio y les paga un sueldo y, como contraparte, ellos deben administrar su finca, lo cual consiste en cuidarla, ver por los animales y rendir cuentas al dueño por la venta de los productos del hato. Se puede decir que es una modalidad de concierto, a saber, una forma de trabajo en la que un "labrador sin tierra [se encuentra] vinculado a una hacienda" (Fals Borda, 1961, p. 320). En este caso, y según el lenguaje local, es una labor en la que un trabajador vinculado a una finca trabaja las tierras de su dueño y del ganado, a cambio de un sueldo y una vivienda. Es una modalidad de migración rural-rural en la que las familias emigran como núcleo; muchas de ellas dejan 
sus lugares de origen y sus propias tierras debido a las crisis económicas que las obligan a proletarizarse en otros lugares. Estas familias basan su economía migrante en la capacidad de venta y cantidad de mano de obra que puedan ofrecer (Flores y de Grammont, 2003). Estos autores definen este tipo de migración como circular, es decir, un cambio de residencia constante sin regreso inmediato al lugar de origen, sino hacia otro frente de trabajo.

Adicional a esta inestabilidad laboral, los planes de desarrollo municipal no han sido suficientemente eficaces en combatir el desempleo rural por falta de subsidios, asistencia técnica al productor, acceso a la tierra, entre otros. Parte de la problemática de la situación de Pueblo Viejo tiene que ver con el actual Plan de Desarrollo de Guasca que entiende que el desarrollo es corresponsabilidad entre las instituciones y la comunidad:

El Plan de Desarrollo 2012-2015 construye sus objetivos estratégicos, sus programas, proyectos y subproyectos bajo una concepción multidimensional del desarrollo, lo cual implica trascender la actuación sectorial del estado y proponer nuevos modelos de gestión y de relacionamiento con la ciudadanía corresponsable de su propio desarrollo. (Municipio de Guasca, 2012, pp. 26-27. Cursivas del autor)

El Plan de Desarrollo Municipal de Guasca habla de medidas frente a la asistencia técnica al productor, al presentar un modelo ideal para "la alta productividad y competitividad en el desarrollo económico” (2012, p. 141). No obstante, 
este modelo no se aplica para el caso de los pobladores de la vereda, como se pudo apreciar durante el desarrollo del trabajo de campo.

Los pequeños ganaderos locales que trabajaban de forma independiente, hasta donde se apreció en el trabajo de campo, no contaban con ningún tipo de asistencia técnica para las labores ganaderas, ni mucho menos con algún tipo de subsidio. Estos planes de desarrollo buscan descentralizar las funciones estatales y responsabilizar a los pobladores locales frente al crecimiento económico y la mejoría en la calidad de vida. Esto es contraproducente en la medida en que las instituciones pueden evadir parte de sus responsabilidades al respecto, lo cual genera abandono en asistencia a los productores, muy propia de la situación de lugares como Pueblo Viejo, y, por consiguiente, bajos niveles de competitividad en el mercado, infraestructura, ingresos y calidad de vida. Toda esta problemática laboral que ahora predomina en la vereda se consolidó en buena medida luego del cierre de la mina y la empresa:

-Felipe Rojas: ¿Cuál es la situación laboral de acá de Pueblo Viejo?

-Vecino: Por este lado, pues lo que más es en la ganadería ahorita. De cultivo, ya muy poco. Todo es más o menos ganadería lo que mantienen acá por toda esta parte, de Pueblo Viejo. Porque como le había dicho, antes ocupaban mucha gente por la explotación de la piedra para la cal. -F: O sea que con relación a lo que era la mina y lo que es ahora la ganadería, el cambio en cuanto al trabajo... 
-V: No, eso cambió en más de un 80 \% por el desempleo, eso cambió mucho.

-F: ¿Y el cierre de la mina, eso fue lo que generó que la gente empezara a buscar otras opciones?

-V: Claro, sí porque de todas maneras allá había mucha gente trabajando. Tenían sus casas ahí [cerca a la mina]. (Entrevista a vecino del sector, 20 de agosto de 2012)

Según el certificado de existencia y representación legal de la Cámara de Comercio de Bogotá, la compañía explotadora de cal fue fundada en el año 1931 (Cámara de Comercio de Bogotá, 2012). El último movimiento que registra esta empresa fue llevado a cabo en 1979 y corresponde a la liquidación de la sociedad. Sin embargo, la mina siguió funcionando hasta el año de 1992, pues legalmente la figura de "liquidación" no representa un impedimento para su funcionamiento. A simple vista, se puede apreciar que la mina funcionó por más de sesenta años, por lo que no es de extrañar que para los vecinos, esta constituya un importante referente de oferta de trabajo en la región.

Por esta razón, parte de la problemática que aborda esta investigación tiene que ver con la manera como la existencia de la RBE en el mismo lugar en donde antes operaba la mina es objeto de reparo a nivel laboral para muchos de los vecinos. Este problema tiene dos ejes analíticos. En primer lugar, están las expectativas de trabajo en la RBE que expresan los vecinos y su situación frente a la cantidad, las formas de empleo y los contratos laborales ofrecidos por la FNC. La responsabilidad que se le reclama a la FNC como empleador local tiene que 
ver con la añoranza por la mina que existía en el mismo lugar que la RBE. Por su parte, si bien existen otras instituciones responsables del problema laboral en Pueblo Viejo como la Alcaldía Municipal, la Gobernación de Cundinamarca, el Ministerio de Agricultura, el Gobierno nacional, Corpoguavio, entre otros, en campo se pudo apreciar que la población local reiteradas veces asumía la responsabilidad en el cierre de la mina, la FNC y las fincas aledañas.

Solo en una ocasión se le asignaron al Gobierno nacional la responsabilidad por el cierre de la mina y el perjuicio que esto causó a nivel laboral. No se desconoce la presencia y responsabilidad de otros actores institucionales, pero su ausencia hace parte de los hallazgos en campo en donde no se tuvo la oportunidad de apreciar sus acciones, ni escuchar las opiniones al respecto por parte de los vecinos. Por otro lado, se considera que la ausencia de otras instituciones hace parte de la misma descentralización de las funciones estatales muy propia de la discusión que se plantea en esta investigación. En segundo lugar, se encuentran las disputas por el aprovechamiento de la tierra, que si bien tienen que ver con el trabajo, se abordarán en el capítulo III, pues implican otro tipo de discusiones con respecto a la forma en que los habitantes de la zona entienden los recursos naturales y su uso. Al preguntar a una vecina del sector su opinión sobre el cierre de la mina a nivel laboral, respondió:

¡Ay a nivel social sí nos perjudicaron enormemente!, porque entonces se acabó el trabajo. La gentecita empezó a emigrar, emigrar y los pocos que tenían por ahí su huertica, 
digamos su pedacito de herencia que aún no habían vendido, jum, buscar cómo vender e irse. Ya otros se fueron muriendo y ya la gente empezó a acabarse. Tan así que ya ahora somos muy poquitos los que quedamos. (Entrevista a vecina del sector, 13 de agosto de 2012)

Durante la entrevista, esta vecina expresó estar de acuerdo con la clausura de las actividades mineras en la vereda, debido al daño que estas causaban a los terrenos y al agua. Por otra parte, su reparo por el cierre, en lo que a lo laboral se refiere, expresa la necesidad de un trabajo con muy buenas condiciones, por lo que la clausura de la mina trajo, en opinión de los vecinos, perjuicios. En la expresión "porque entonces se acabó el trabajo" se considera a la mina como la fuente predilecta de empleo, al equipararla con el trabajo como tal. Dicho de otro modo, si se acaba la mina, se acaba el trabajo.

En otras conversaciones durante el trabajo de campo algunas personas comentaban que el cierre de la mina había sido duro porque era la única fuente de empleo en el sector. Así, hay un contraste entre lo que se añora (el trabajo) y lo que se repara (el daño ambiental) de la mina, en las opiniones locales. Evidentemente, esta equiparación de la mina con el trabajo es una de las causas de que se espere que en ese mismo espacio, en donde tal explotación tenía lugar (hoy la RBE), se provean numerosas y buenas fuentes de empleo.

Con todo, estas opiniones frente a la responsabilidad de la mina en cuanto al empleo hacen parte de una forma particular de recordar el pasado a partir de la situación actual. 
Las dificultades laborales de hoy en día dan pie para rememorar la época de la mina como un periodo de bonanza a nivel laboral. Sin embargo, la responsabilidad por la situación actual no recae solamente en esta empresa, pues está relacionada con problemas más profundos de la ruralidad.

El Plan de Desarrollo Municipal 2012-2015 identifica que los principales problemas económicos del municipio son: "bajos niveles de capacitación, asistencia técnica y trasferencia de tecnología", "nula promoción del desarrollo empresarial”, "baja tecnificación pecuaria”, "desempleo y migración de la población rural”, "bajas inversiones y generación de empleo", "bajos ingresos de la población económicamente activa" y "bajo nivel de apoyo al sector agroindustrial" (Municipio de Guasca, 2012, p. 34). Esto deja ver con claridad que las dificultades laborales y económicas actuales son fruto del cierre de la mina a pequeña escala y superficial, pero consecuencia de la falta de unas políticas de desarrollo rural claras y consistentes, en un nivel más profundo y amplio.

Los testimonios orales que se recolectaron en campo discrepan sobre las razones del cierre de la mina. En el testimonio que se citó al inicio de este capítulo se asegura que la explotación se acabó porque el señor Hermann Hoeck, socio mayoritario de la empresa, murió y no hubo quién siguiera al frente de la mina. Esta vecina añade que la empresa también se acabó porque el Gobierno la privatizó, así como lo hizo con muchas otras compañías, lo que para ella tenía que ver con trabas que el Gobierno ponía al funcionamiento 
de este tipo de explotaciones. Es decir, la intervención del Gobierno en contra de la mina fue un acto que fomentó su privatización, su cierre, lo que puede llevar a pensar que esta persona, a pesar de saber que la empresa era de la familia Hoeck, concebía la explotación como un empresa pública, tal vez en el sentido de pertenencia y generación de beneficio a la población local. Algunos otros vecinos plantean razones diferentes para el cierre de la explotación:

Pues se cerró porque ahí el obrerismo que había fundó un sindicato y entonces eso les quedaba muy pesado a los patrones para cumplirles con todas esas peticiones que les pedían. $\mathrm{Y}$ entonces ese sindicato que fundaron fue para mal de ellos. (Entrevista a vecina del sector, 13 de agosto de 2012)

-Vecino: Hasta que se acabó, se murió el doctor [Hermann Hoeck].

-Felipe: ¿Y por qué se acabó entonces?

-V: Porque él la dirigía.

-F: ¿Pero no estaban don Hendrik y don Tomás [hijos de Hermann Hoeck]?

-V: Sí, pero ellos ya no, ellos tenían minas por el otro lado, por el lado de tierra caliente. Tenían mármol, tenían mucha tierra por todo lado. Ya para qué más. Y acabaron con la empresa.

-F: ¿O sea que se acabó porque no había quién la administrara? 
-V: ... se murió el doctor, los hijos todavía no tenían así uso de razón para manejarla, entonces... cerraron eso. (Entrevista a vecino del sector, 20 de diciembre de 2012)

En este fragmento se equipara la finalización de la explotación con la muerte del señor Hoeck, como lo conciben varios habitantes del sector. Algunos otros vecinos aseguran que la mina se cerró debido a malos manejos, lo que la llevó a declinar económicamente; ya no había dinero para pagarles a los obreros y terminó quebrando:

Ahí se acabó la mina fue por, por mala administración, porque vino una señora que trabajaba de secretaria en Bogotá, en la oficina de, donde tenían una oficina que se llamaba El Apagadero creo, que era donde llevaban allá también la cal. [...] imagínese, ¿una señora de oficina qué va a saber de minas? Entonces ella hizo todo lo contrario, en lugar de destapar para buscar la piedra y eso, lo que hizo fue tapar y ya de un momento a otro se acabó, sí, porque ya que no había plata para pagarle a la gente, sí, mejor dicho miles de disculpas. Ya ella empezó a no darle empleo a la gente, porque que no alcanzaba la plata y por ejemplo la maquinaria que había, entonces ya con esa maquinaria ella le pagó a los que quedaban...y ya quedó prácticamente nada de la empresa, de la empresa de cal. (Entrevista a vecina del sector, 27 de agosto de 2012) 
Otra vecina comentaba, cuando se le preguntó por la situación laboral en épocas de la mina y las razones de su cierre:

Pues más bien trabajo sílo había. Había harto trabajo. En ese tiempo sí tenían harto trabajo los obreros que ahí sí trabajaban. Eso sí tuvieron harto trabajo, sí señor. Hasta que ya se terminó la piedra y fue que ya dejaron ahí la mina quieta, que ya no salía más piedra [...]. Por lo que se acabó la piedra. Ahí ya no hubo más roca de piedras. Hasta donde estuvo la roca de piedra bien y entonces se terminó y por eso ya no trabajaron más. (Entrevista a vecina del sector, 2 de septiembre de 2012)

Esta cita expresa dos cosas. Por un lado, está la opinión de un cierre que tuvo que ver con la escasez del mineral; otro vecino aseguraba que al final ya costaba mucho sacar la piedra a causa de su escasez. Por otra parte, la cita muestra la manera como es recordada la época de la mina a nivel laboral como un periodo de abundancia de ofertas de empleo. Además, la añoranza por el trabajo en la mina y las dificultades laborales de la actualidad son aspectos expresados de la siguiente manera por la vecina citada anteriormente:

Pues cuando estaba la mina tenían más trabajo que ahora. Claro que ahora tienen, trabajo tienen, pero en cambio en ese tiempo había más trabajo por lo que la mina allíla gente más cerquita, todos los que vivían en esta vereda, porque ya todos casi se murieron de verdad, entonces tenían ahí 
su trabajo más bien. Les quedaba más cerquita para el trabajo. Entonces en ese tiempo les quedaba más fácil para los trabajadores de la mina. Ahí sílos que trabajaban ahí en la mina y los otros abajo en el horno. (Entrevista a vecina del sector, 2 de septiembre de 2012)

Las figuras 5 y 6 ejemplifican parte de las formas de trabajo en la extracción y trasporte de la piedra de cal y dan alguna idea del número de puestos de trabajo que ofrecía la mina de cal de Guasca. En la figura 5 se aprecia a 15 trabajadores sacando y cargando la piedra, mientras que en la figura 6 están usando compresores para partir la roca de cal.

\section{Figura 5. Mina de cal en el año 1955}

Trabajadores partiendo y cargando la piedra caliza (autor desconocido)

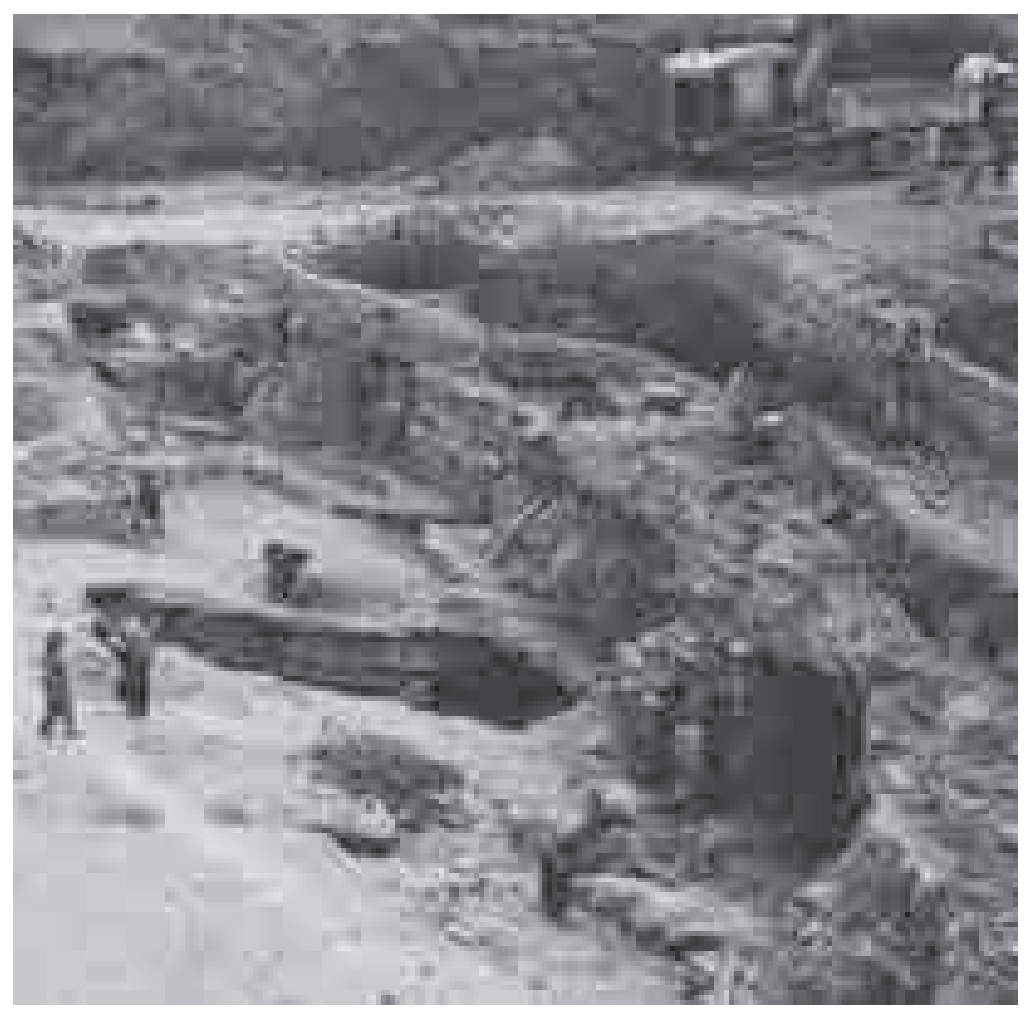

Fuente: cortesía FNC y Hendrik Hoeck. 
Figura 6. La mina de cal hacia el año 1963

Trabajadores usando compresores para partir la piedra (autor desconocido)

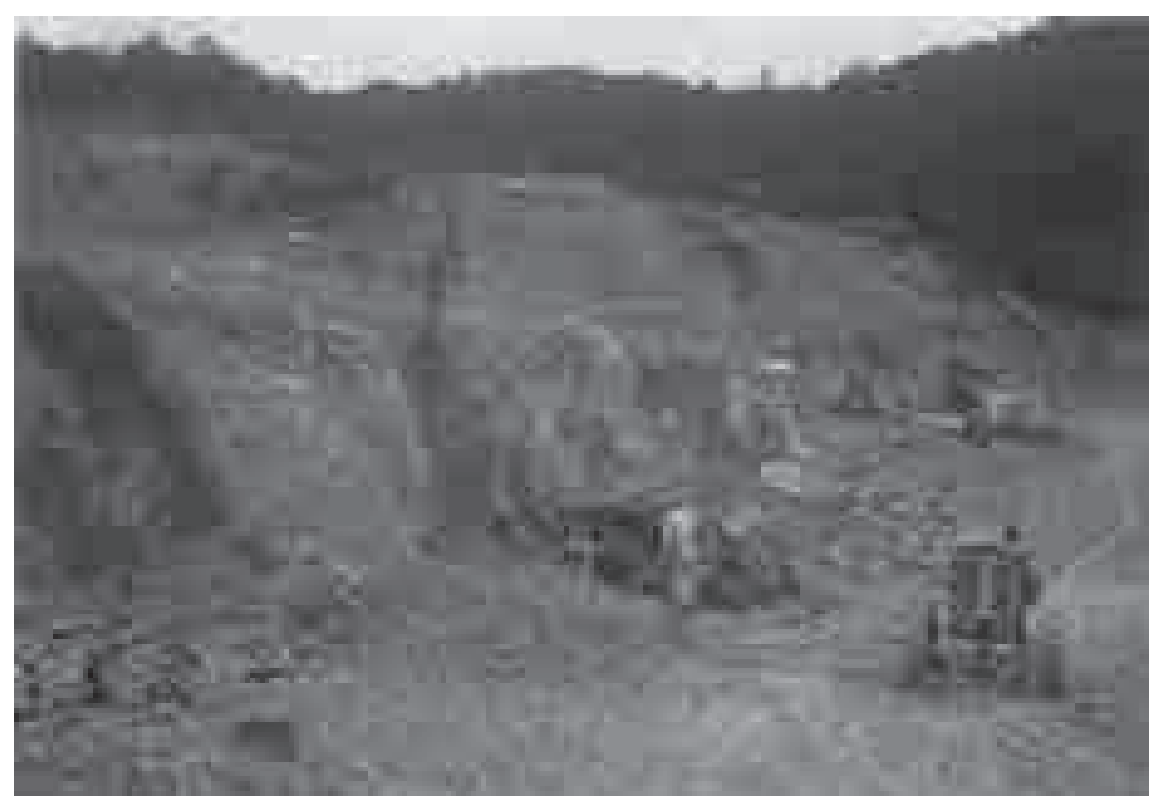

Fuente: cortesía FNC y Hendrik Hoeck.

Tal como se ha venido argumentando, la situación laboral actual no es muy bien vista por los habitantes locales y el fragmento de entrevista citado líneas atrás es una muestra de ello. En primer lugar, la cantidad de trabajos que ofrecía la mina es añorada en la época actual en donde las ofertas son limitadas y un tanto escasas. Por otra parte, esta situación de escasez de la oferta trae consigo un agravante que la vecina expresa como la cercanía del trabajo. Al no haber trabajo cerca, la gente debe desplazarse, lo que es visto como una dificultad laboral local. En cambio, en la época de la mina había dos cosas fundamentales para el trabajo en el sector: oferta y cercanía, por lo que muchos vecinos ven ese periodo como un momento de bienestar a nivel laboral, pese a sus reparos sobre lo pesado del trabajo y las afectaciones en la salud que causaba la mina. 
En contraste con parte de las opiniones de los habitantes locales que se han venido reconstruyendo, la FNC les comenta a los visitantes de la RBE que la mina fue cerrada por la toma de conciencia del señor Hendrik Hoeck frente al daño ambiental que esta causaba. En una conversación con el señor Hoeck, este comentó que a inicios de los noventa estuvo conformada en el lugar la Fundación Encenillos en conjunto con la Universidad de los Andes, cuya finalidad era proteger esos bosques y operó a mediados de la década de 1990. Esta fundación fue creada después del cierre de la mina, pero luego fue disuelta debido al auge guerrillero en la región. La trayectoria profesiona ${ }^{10}$ y personal del señor Hoeck indica que el cierre de la mina tuvo que ver con buena parte de los factores expuestos por las distintas voces de Pueblo Viejo. La conciencia ambiental del señor Hoeck fue un factor clave, pero también la muerte de sus padres, pues no solo dejó a la empresa y la explotación sin sus principales directores y dueños, sino que produjo posteriormente una repartición de los bienes entre los tres hijos. Así, el señor Hendrik Hoeck decidió, luego del cierre de la mina, conformar una reserva natural en parte de las tierras que recibió en herencia,

10 Es biólogo de la Universidad de los Andes y de la Universidad de Múnich, hijo de los socios mayoritarios de la compañía explotadora de cal y heredero, junto con sus dos hermanos, de los predios que sus padres compraron en la región; es socio fundador de la Fundación Humedales Colombia y de la asociación Swiss Friends of the Galápagos Islands; miembro del Global Nature Fund (Alemania), Ubuntu Foundation (Suiza), Fundación Charles Darwin (Ecuador) y de la FNC; trabajó su tesis doctoral en biología en el comportamiento y ecología de los damanes, un mamífero pequeño de África, en el Instituto Max-Planck Seewiesen, Departamento de Zoología de la Universidad de Múnich (Fundación Humedales, s. f., comunicación personal con Hendrik Hoeck, febrero de 2013). 
hasta que finalmente en el año 2007 se conformó la RBE de la mano de la FNC. Por otra parte, la explotación del mineral después de tantas décadas de trabajo se fue agotando y dificultando su extracción, lo cual fue otra de las causantes de declive y posterior cierre, además del deslizamiento, la erosión y el daño ambiental que estaban sufriendo algunos terrenos.

\section{El trabajo en la Reserva Biológica Encenillo: una misma tierra, labores distintas}

Nunca ha dejado de ser una razón de asombro el hecho de que en el mismo lugar donde duró 61 años una explotación de piedra caliza exista hoy en día una reserva biológica. El asombro proviene del profundo contraste que suponen actividades como la minería a cielo abierto y la declaración de áreas protegidas. Dentro del estudio de los conflictos ambientales, propio de la ecología política y la antropología ambiental, fue objeto de interés de esta investigación indagar por cuáles son las implicaciones de la constitución de un área de conservación ambiental para los pobladores locales. Investigaciones como las de Brenner y Job (2006) y Orozco et al. (2008) trabajan temas relacionados con la constitución de áreas protegidas, en este caso, la Reserva de la Biósfera Mariposa Monarca, en México, declarada en 1980. Por su parte, Troncoso (2008) aborda la declaratoria de la Quebrada de Humahuaca Jujuy en Argentina como patrimonio natural y cultural de la humanidad como propuesta de desarrollo basada en el turismo. Estas tres investigaciones abordan el problema del desarrollo sostenible, expresado en el ecoturismo, como una de las formas de manejo de las áreas 
protegidas, en aras de mitigar el impacto ambiental, la falta de puestos de trabajo y la pobreza de las poblaciones aledañas a áreas naturales.

La región en la que trabajan Brenner y Job (2006) y Orozco et al. (2008) se caracteriza por la alta marginalidad de su población campesina e indígena y unas condiciones socioeconómicas adversas que dificultan el desarrollo local y la protección ecológica. Parte de su intención es analizar hasta qué punto esta forma de desarrollo sostenible supone bienestar económico para estas poblaciones aledañas a la reserva en contextos de pobreza campesina, falta de oportunidades laborales e impacto ambiental. En el caso de Troncoso (2008), la declaratoria patrimonial de la quebrada fue una estrategia que buscaba mitigar el impacto del desempleo por cuenta del cierre de diversas empresas a través del turismo como modelo de desarrollo.

Estos casos ponen de presente que el ecoturismo se ha convertido en una variable clave dentro de las formas de trabajo ofrecidas por las áreas protegidas. Sin embargo, el alcance de esta actividad puede llegar a ser muy limitado en lo que respecta a ofrecer medios de subsistencia a las poblaciones locales. Brenner y Job (2006) aseguran que el ecoturismo no ha sido una opción viable para estas personas, por lo que el impacto ambiental sobre los recursos ha continuado e, incluso, la pobreza no ha podido ser mitigada.

Troncoso (2008) sostiene que el turismo ambiental no ha respondido a las necesidades económicas locales porque las ganancias de este negocio se las llevan principalmente los empresarios. Por su parte, Orozco et al. (2008) cuestionan 
la existencia de un desarrollo realmente sostenible en las prácticas del proyecto ecoturístico desarrollado en la reserva que estudian, pues aseguran que no solo no ha servido para mitigar la pobreza y el impacto ambiental, sino que, incluso, las prácticas turísticas han generado mayor deterioro sobre los ecosistemas. A su vez, Hernández et al. (2005), en su análisis en busca de estrategias para mitigar el deterioro ambiental y la pobreza en cuatro comunidades marginales y empobrecidas al sureste del estado mexicano de Oaxaca, establecen una correspondencia entre ambas, en lo que han denominado un "círculo vicioso": la existencia de pobreza es un potencial generador de deterioro ambiental. En la misma línea, Orozco et al. (2008) proponen que hay una correspondencia entre uso inadecuado de los recursos del entorno y pobreza.

En Argentina, existen casos similares como los del Parque Nacional Lanín, cuya constitución propuso cambios en las actividades ganaderas de la población local, control sobre el uso de los recursos naturales e introducción de otro tipo de labores como el turismo (Osidala et al., 1992). Por su parte, en la reserva faunística del Chimborazo, en Ecuador, se propusieron modelos de desarrollo local basados en el ecoturismo como forma de manejo con un enfoque diferencial de género y la puesta en marcha de un diálogo entre las partes involucradas para la resolución de conflictos por el manejo de recursos ambientales y el trabajo (Burbano, 2005).

Para el caso de la Reserva Biosfera Maya en Guatemala, se identifican problemas relacionados con la existencia de estas zonas protegidas en áreas habitadas y en relación con el uso de los recursos naturales y las alternativas que se deben gene- 
rar a nivel económico, bienestar social y cuidado ambiental a través del desarrollo sostenible (Monterroso, 2006). Lo común a estos casos, y que es relevante analíticamente para esta investigación, es el cambio en las actividades económicas que supone la declaratoria de áreas de conservación a nivel planetario. En la mayoría de los casos, se restringen ciertas labores, mientras se propone el ecoturismo como aquella "fórmula mágica" de empleo y desarrollo para la población local. Ello supone tendencias globales sobre la manera de entender el trabajo en áreas de conservación ambiental de las que Guasca no es ajena porque, como se ha reconstruido, la principal actividad laboral en esta reserva es el ecoturismo.

El ecoturismo ha sido criticado tanto por su impacto ambiental, es decir, cuestionando su presumible sostenibilidad, como por su real posicionamiento como alternativa económica para la población. Durán (2009) y Ojeda (2012) exponen que, para el caso del Caribe colombiano, en el ecoturismo las poblaciones locales son empleadas o se les permite ejercer las labores menos lucrativas, mientras que las empresas privadas obtienen las mayores ganancias de este negocio. Además cuestionan la supuesta sustentabilidad de esta actividad económica, como ha sido desarrollada a gran escala, pues no solo genera mayores desechos que afectan al ambiente, sino que permite la realización de actividades en pro de acrecentar sus ganancias en discordancia con las políticas de conservación (Durán, 2009; Ojeda, 2012).

Estos casos tienen en común, además, la situación de falta de oportunidades laborales y de calidad del empleo, las restricciones sobre el manejo y uso de los recursos del 
ambiente y la pobreza en el sector rural. ${ }^{11}$ El debate específico que surge aquí tiene que ver con la calidad y cantidad de las oportunidades laborales que puede brindar un proyecto de conservación ambiental basado en prácticas como el ecoturismo. Esto implica analizar de qué forma las políticas laborales asociadas a la conservación alteran las formas locales de relación con el entorno a través del trabajo. Si el trabajo (minero y agropecuario, en el caso de Guasca) es una forma de apropiación de la naturaleza en el área rural, su trasformación supone modificaciones sobre las formas de entendimiento y relación con el ambiente.

Los casos mencionados muestran que la constitución de áreas de conservación es una tendencia mundial en la actualidad que altera las condiciones de vida locales al restringir o cambiar los usos de los recursos del entorno y proponer nuevas actividades laborales, como sucede en Guasca. A nivel teórico, y siguiendo el enfoque de la Nueva Ruralidad, esto sugiere que actualmente en el campo lo agropecuario no es la única forma de actividad económica, pues existen otro tipo de labores relacionadas con los servicios turísticos y ambientales que han tomado fuerza (Echeverri y Ribero,

11 Según el más reciente informe nacional de desarrollo humano para Colombia, publicado por el Programa de las Naciones Unidas para el Desarrollo (PNUD), la brecha entre las áreas urbanas y rurales ha aumentado, de manera que la reducción de la pobreza en el campo ha sido menor que en la ciudad. Establece, además, que a mayor índice de ruralidad en los diversos municipios del país, mayor pobreza y menor consecución de los objetivos del milenio. Gran parte de los problemas de pobreza y desarrollo en el sector rural tienen que ver con la concentración de la propiedad, la dificultad en la generación de ingresos y la falta de empleos permanentes y dignos (PNUD, 2011). 
2002), aunque no siempre en beneficio de las poblaciones. Este enfoque teórico propende por entender la complejidad de lo que es la ruralidad, muy acorde con lo que acontece en Guasca en donde conviven diferentes actividades labores, no siempre congruentes entre sí ni libres de tensiones. En el caso de la RBE, el cambio se dio de una explotación minera y agropecuaria a una reserva de la sociedad civil administrada por una ONG ambiental.

Así como lo muestra la figura 1, la FNC emplea actualmente a seis personas, cinco $^{12}$ de las cuales son contratadas por días para la realización de actividades de aseo, cocina y como guías turísticas de los visitantes de la RBE. El otro empleo corresponde a la administración residente de la reserva, una persona que cuenta con un contrato laboral a término fijo y prestaciones sociales. Las otras cinco personas son llamadas ocasionalmente, cuando hay eventos y se reciben decenas de visitantes en la reserva, para preparar y servir los alimentos, hacer aseo antes y después de su llegada y ofrecer guías por los senderos de la RBE. Todas las labores ofrecidas giran en torno al ecoturismo como principal actividad económica desarrollada por la FNC en la RBE. Ello implica que los guías deben ejercer algunas nuevas formas de trabajo

12 Adicional a estos cinco trabajadores, durante unos meses la FNC empleó los fines de semana a una pareja de hermanos adolescentes que hacían labores de mantenimiento de las instalaciones de la FNC en el sector, servicios generales, recibimiento de los turistas, y se estaban preparando para ser guías turísticos. Estos jóvenes eran estudiantes de la IED El Carmen, sede El Salitre, y residentes de Pueblo Viejo. Después de unos meses de trabajo, parece que la FNC no estuvo a gusto con la labor desempeñada por estos jóvenes, por lo que no continuaron con su labor. 
(interactuar con turistas, cocinar para ellos, limpiar sus desechos y explicarles sobre la fauna y la flora), así como nuevas maneras de entender el entorno (aprender nombres y denominaciones científicas).

En las observaciones en campo, se pudo apreciar que ese trabajo en ecoturismo no era lo suficientemente estable. Se constató que el actual jefe de reserva, en comparación con los anteriores, y en opinión de los vecinos, ha traído mayor número de visitas, por lo que una o dos veces a la semana se hacen actividades en la reserva en las que se requieren los servicios de estas personas que trabajan por días. Sin embargo, de los siete días de la semana, solo entre uno y tres estas personas son empleadas para hacer trabajos en la reserva, por lo que esta labor no se convierte en una actividad que les permita sobrevivir; más bien es un ingreso complementario a otro tipo de actividades laborales principales, como la ganadería.

En las observaciones que se hicieron de los eventos que llevaba a cabo la FNC en el lugar, me percaté de que empleaba en promedio tres trabajadores locales, distribuidos entre guías, cocina y aseo. Eventualmente, la FNC ha brindado trabajo a los maestros de obra locales en actividades de remodelación de sus instalaciones o de arreglos, pero estas labores han sido ocasionales y, en su mayoría, se concentraron en el inicio de la reserva en la que se efectuaron algunas obras de adecuación de las instalaciones del FNC en el lugar para las actividades a desarrollar, entre ellas el ecoturismo. Otro tipo de trabajo en el que la FNC ha empleado a los pobladores locales ha sido en la plantación de árboles y su posterior 
mantenimiento (conocido comúnmente como "plateo"), pero no han sido labores frecuentes ni regulares.

En contraste con lo que fueron los años de la mina, la FNC no ofrece empleos de la misma manera en cuanto a cantidad y calidad. En suma, para los habitantes de la zona, la RBE no ha representado una alternativa laboral en medio de la falta de opciones de empleo en el sector:

Mire que la gente le toca salir, más que todo la juventud, a la mayoría les toca salir a buscar trabajo porque acá no hay. Acá lo único así es, pues lo ganadero [...] Juventud acá como tal ya no hay porque oportunidades de empleo no hay. Y si hay, no es nada seguro. Por ejemplo, en las fincas los administradores se creen como los dueños y sí, tratan a la gente mal. A veces la gente se va por eso. Vienen, van porque el trato no es bueno. Sí, la gente trata de dar lo mejor de sí, pero pues por los hijos, por el trabajo y todo, por necesidad ¿no? Pero pues el trato de los jefes como tal no es bueno y les toca irse. Lo digo en el caso de las fincas que están acá alrededor. Pero como tal pues la parte laboral acá me parece que no es buena. Por eso es que la gente tiene que irse de acá. Y los que, o sea, están acá es porque ya tienen su casa, tienen algo seguro, ¿`sí? Aquí no hay oportunidades de empleo. Hubiera flores o ¿qué sé yo? Mm..., fresas o eso, pero acá no. Pues la Fundación [Natura] sí, pero igual ahí, ahí qué, abi no hay trabajo. (Entrevista a vecina del sector, 27 de agosto de 2012. Cursivas del autor) 
Esta vecina considera, en medio de sus reparos por la situación laboral del lugar y la migración que ello ha supuesto de la juventud local, que la FNC no ofrece mucho trabajo, pues considera que en la RBE no hay mucho por hacer. La baja oferta laboral en la reserva tiene que ver con varios factores. En primer lugar, el uso de los recursos naturales que proponen en reforestación y cuidado de los bosques entra en conflicto con los usos "tradicionales" locales que pueden llegar a ofrecer mayor trabajo, pero cuyo impacto ambiental puede ser mayor (el problema de los usos del suelo en la RBE se abordará en el capítulo III). En segundo lugar, la poca oferta de trabajo que brinda la FNC tiene que ver con la forma en la que se desarrollan las actividades ecoturísticas en la RBE. En general, las labores de guías son ejercidas no solo por habitantes locales, también se emplean personas foráneas, principalmente de Bogotá. Esto supone tensiones con la población local:

Aquí debían ocupar la gente. Debían de rotarla, "bueno usted va hacer esto, usted va hacer esto, en ciertos días va ocupar en [...]" así. ¿Lo ve? Entonces, esa reserva sí estaría dándole beneficio a las personas del mismo municipio, a las personas del mismo sector. Pero no, prácticamente no. No porque digamos porque no traigan gente de otro lado, no. Pero es que realmente tiene más obligación, tiene más derecho la gente de acá. (Entrevista a vecino del sector, 3 de septiembre de 2012) 
Los vecinos del sector consideran que las personas del lugar tienen más derecho a trabajar en la RBE que las personas foráneas. Esto no solo demuestra un arraigo territorial, sino un reparo a que la FNC traiga guías externos para las actividades en la RBE. Y es que sumado a la situación laboral del sector, evaluada por los vecinos como mala, en especial por la baja oferta laboral y la poca estabilidad que existe en las fincas contiguas, la FNC no está cumpliendo con buena parte de sus expectativas laborales. En otra entrevista con dos vecinos, dieron las siguientes respuestas al respecto:

-Felipe Rojas: Porque tengo entendido que también a veces han traído guías es de Bogotá.

-Vecino 1: Imagínese habiendo gente acá, prácticamente capacitada.

-Vecino 2: Una persona de Bogotá qué historia le va a contar a uno.

-Vecino 1: O es que yo creo que hasta ni se saben el nombre de los árboles o por qué, si este da unos frutos que se puede comer uno o no. (Entrevista a ganaderos locales, 8 de septiembre de 2012)

Su reparo está mediado, al igual que el anterior, en considerar que las personas de la vereda deberían hacer el trabajo. Es más, estos vecinos argumentan por qué deberían hacerlo, aducen a las capacidades que tienen en cuanto al conocimiento de su entorno y la historia del lugar. Toledo y Barrera (2008) sostienen que las poblaciones locales tienen un conocimiento de su entorno debido a años de experimentación, interacción 
con el ambiente y procesos de trasmisión nemotécnica de estos saberes. Si bien su argumento parte de consideraciones esenciales sobre lo étnico y tradicional, extendiéndolo a grupos no marcados étnicamente, es pertinente. En el caso de Guasca, adquiere relevancia pensar cómo, desde esta opinión citada, existe un desconocimiento de los saberes locales en las prácticas ecoturísticas promovidas por la FNC.

En cuanto al trabajo, este desconocimiento se basa en traer guías externos que carecen del saber local sobre el entorno, pero que son empleados por ser biólogos, saneadores ambientalistas o tener relación con estas áreas del conocimiento. Esto sugiere que los discursos ambientales pueden implicar tensiones constantes con los conocimientos locales y la apropiación del lugar. Las comunidades se ven imbuidas en luchas y diálogos con procesos ambientales globales y políticas de administración de los recursos naturales que intervienen sobre el entorno y las formas de vida. Además, los conocimientos son jerarquizados, no en vano los guías deben aprender los nombres científicos. Si bien esto no quiere decir que no se usen los nombres comunes, se les da una mayor validez intelectual a los científicos en las labores ecoturísticas.

Parte de la expectativa local de trabajo en la reserva tiene que ver con la percepción que muchos vecinos tuvieron de esta en el momento de su inauguración, pues gran parte de ellos expresaron que les habían comentado que la idea de constituir la RBE era brindar trabajo a la población local. Sin embargo, no deja de ser problemático que la población asuma que la FNC tiene gran parte de la responsabilidad 
de lo ocurrido y no se cuestionen a otras instituciones como la Alcaldía Municipal o el Gobierno nacional como responsables de la situación laboral de la vereda. Muchos esperan que esta gran porción de tierra, esta finca, como muchos la denominan, y su nuevo administrador (la FNC), continúe siendo un medio de producción que genere empleo, como históricamente lo fue la mina, sin cuestionar cuál es la responsabilidad de otros actores privados y públicos al respecto.

Parte del proyecto de vinculación de los habitantes locales como guías turísticos surgió en el año 2008, por iniciativa de dos estudiantes de Biología de la Universidad Incca de Colombia, que estaban haciendo su tesis de grado en la reserva bajo el apoyo de la FNC y cuyo tema central fue el estado de la avifauna en la RBE. En este proyecto, se "conformó un grupo de eco-guías de ocho personas habitantes de la vere$\mathrm{da}$, los cuales fueron capacitados, con el fin de concientizar a las personas y ofrecer otras formas de trabajo" (Camargo y Moreno, 2008, p. 60, cursivas del autor).

Parte de la intención de este programa consistía en la capacitación de los habitantes locales en el cuidado ambiental. La palabra "ecoguías" sugiere un concepto interesante sobre la manera de entender la labor que debían desarrollar estos vecinos. No solo estarían capacitados para guiar a los visitantes, sino que serían ellos mismos educados para aprender a conservar la reserva y generar conciencia ambiental. El trabajo como ecoguías gira alrededor del ecoturismo y supone la intervención sobre la forma en que los sujetos locales se relacionan y entienden la naturaleza. Las palabras “capacitar” y "concientizar" presentes en la propuesta de 
estos tesistas sugieren una forma de intervención sobre los sujetos para dejar de ser únicamente campesinos, mineros o jornaleros y convertirse en ecoguías.

Este trabajo, en palabras de una pobladora local capacitada en este proceso, no consistía en ser un tipo de guía cualquiera, sino en informar sobre lo que había en el lugar, esto es, sobre la fauna y flora local. Los ecoguías hicieron parte de una iniciativa que si bien no tuvo mayor alcance, es una muestra de las formas en que los proyectos de conservación entienden la labor, las capacidades y el papel de las poblaciones locales en las áreas protegidas. Son una forma de crear sujetos bajo ciertas características, separados del común de las otras personas a través de un proceso de educación.

El trabajo como ecoguías crea una nueva forma de labor, un nuevo sujeto que debe hacer ciertas actividades asociadas al ecoturismo y el cuidado ambiental. Esta labor representa algo novedoso en el lugar, nunca antes practicada como actividad económica. Parte de la novedad consiste en que su base no son las actividades agropecuarias o mineras características de la vereda, sino la necesidad de capacitaciones en temas relacionados con el ambiente y su cuidado.

Mi argumento consiste en que la educación en temas ambientales para el ejercicio de esta actividad modifica parte de, o busca modificar, la percepción que tienen los habitantes sobre la naturaleza. No cualquiera podía ser ecoguía a partir de sus conocimientos del lugar, debía pasar por un proceso educativo en el que se le imprimieran unos conocimientos y una toma de conciencia particular. Esto es, a todas luces, una forma de intervención y creación de unos sujetos particulares, 
en este caso ambientales, ${ }^{13}$ pues la actividad del ecoguía, como estaba planteada, no solo era laboral, sino que implicaba un cuidado constante de la naturaleza en la cotidianidad. Una vecina expresaba lo siguiente sobre su trabajo en la RBE:

Pues eso es bonito. O sea es una experiencia bonita porque uno aprende, empezando porque uno vivía acá y no sabía los nombres de los árboles nativos, eso sí aprende uno bastante. (Entrevista a habitante local, 3 de septiembre de 2012)

Este fragmento, además de mostrar el agrado de algunas personas que han trabajado como guías en la RBE, ejemplifica parte de las formas en que los procesos políticos ambientales (en este caso de ofrecimiento de trabajo en áreas de protegidas) modifican e intervienen las maneras de pensar, conocer y entender la naturaleza. Esta vecina expresaba que no conocía los nombres (científicos) de las plantas nativas, y aduce su importancia para la aprehensión del entorno y el desempeño en el trabajo como ecoguía. Algunos otros vecinos consideran

13 Este concepto tiene que ver con la construcción que el ambientalismo hace de unos individuos y grupos humanos como tendientes a la conservación y el cuidado ambiental. Desde una perspectiva foucaultiana, Agrawal (2005) esboza este concepto de producción de sujeto ambiental para denotar cómo las tecnologías de gobierno y poder ambiental crean unos sujetos determinados acordes con las intenciones de conservar la naturaleza. Parte de la crítica a este concepto versa sobre la no automaticidad de la producción de sujetos, esto es, considerar que los individuos acogen pasivamente estas tecnologías de gobierno y son producidos como ambientales de forma automática y total. Uno de los autores que propone esta crítica es Cepek (2011) en su texto Foucault in the Forest: Questioning Environmentality in Amazonia. 
que están bien capacitados para ejercer esta labor de ecoguías, mientras que otros expresan que les hace falta mayor capacitación y una biblioteca para consultar, en especial sobre la flora y la fauna para realizar las explicaciones a los visitantes. Todo este cambio en las formas de aprehensión del ambiente no es inmediato, sino que hace parte de una serie de tensiones y negociaciones. Así, los procesos políticos y económicos derivados del ambientalismo aterrizados a escalas locales suponen tensiones entre formas de conocer y conceptualizar el ambiente. Las lógicas científicas intervienen las maneras de conocer y entender la naturaleza que han ejercido estas poblaciones por generaciones. En otras palabras, en este escenario se presentan tensiones por los significados de la naturaleza y su conocimiento (Escobar, 2005).

De las ocho personas capacitadas para esta labor, solo dos la ejercen actualmente con regularidad, es decir una vez a la semana por lo menos. Algunas de las personas restantes nunca fueron llamadas a ejercer el trabajo, mientras que otras se retiraron por falta de un contrato fijo, de regularidad del trabajo ofrecido por la FNC (lo cual en muchas ocasiones interfería con sus labores en la ganadería), por falta de un salario fijo o por motivos personales:

-Vecina: Pero ya le digo, yo me retiré fue por lo que ahí sí no era un sueldo fijo. Y después ya me puse a trabajar en el ordeño entonces ya llega uno muy cansado para ponerse en esas carreras de que corra pa' un lado y corra para el otro. -Felipe Rojas: Y sumercé me dice que no siguió porque la llamaban cada mucho tiempo. 
-V: ya últimamente me estuvieron llamando, pero ya no tuve tiempo porque ya me metí a trabajar en una parte donde, pues donde uno tiene un sueldo fijo. Porque como allá no era sueldo, o sea era una vez al mes o por allá cada dos meses. Entonces ya me metí a trabajar en una parte donde estoy trabajando, estoy ganado un sueldo fijo que sé que me va a llegar quincenas. En cambio allá no tenía esa posibilidad.

-F: ¿Y sumercé dónde está trabajando?

-V: pues en el ordeño, pero de todas maneras es un sueldo fijo que uno tiene. Entonces ya no me queda tiempo porque yo ya llego aquí, toca estar, cuando está trabajando en la reserva uno tiene que estar allá a las siete y media de la mañana, arriba, pa' esperar ahí sí los visitantes y yo estoy llegando aquí a las ocho. Entonces mientras llego y me desayuno y no para estar en esas carreras ya estoy muy vieja. Ya no.

-F: ¿Y entonces sumercé en qué condiciones hubiera seguido trabajando ahí?

-V: Que hubiera sido un sueldo fijo. Que uno le dieran, por ejemplo, le dieran a uno sus dotaciones, por ejemplo las botas, el uniforme [...]. (Entrevista a vecina del sector, 3 de septiembre de 2012)

Otro de los debates que subyace a propuestas como la de los ecoguías tiene que ver con una conservación incluyente contra una excluyente. En este caso, este pequeño proyecto de dos estudiantes que contaron con el apoyo de la FNC representó, de alguna manera, una apuesta de inclusión 
de los pobladores locales en el proyecto de conservación. Campos y Ulloa (2003) abogan por la importancia de los pobladores locales en el manejo de los recursos naturales junto con otro tipo de actores gubernamentales y no gubernamentales. Aseguran que la solución a los problemas ambientales no solo debe ser desde el trabajo de la academia, sino desde los saberes y las prácticas de aquellos actores que están todo el tiempo relacionados con los recursos naturales. Esto plantea la necesidad y el derecho de inclusión de los pobladores locales en el manejo de recursos naturales en áreas protegidas.

En consecuencia, el proyecto de los ecoguías si bien fue una forma de inclusión incipiente, se encontraba bajo preceptos que no reconocían del todo los saberes locales sobre el entorno, pues la capacitación fue en una sola vía (de la FNC hacia la población). En efecto, no fue una propuesta efectiva de involucramiento local en el manejo de la RBE, pues no implicaba la toma decisiones y la concertación de planes de manejo, elementos clave para la participación local en el manejo de zonas de conservación ecológica.

Por consiguiente, estos propósitos de inclusión y trabajo de los ecoguías, planteados por los dos estudiantes, no se han consolidado. En primer lugar, la baja participación de la población en general en estas labores es un factor en su contra. Si bien existe interés por parte de la población en relacionarse con la RBE y hacer propuestas de desarrollo de actividades económicas allí, son muy pocos los pobladores que han comunicado esas inquietudes a la Fundación, debido a la falta de canales establecidos de comunicación periódica entre las partes. 
Las personas del sector se comunican con la FNC a través del administrador residente y el jefe de la RBE en conversaciones casi siempre relacionadas con temas de venta de pastos o trabajos ecoturísticos. De resto no hay mayor interacción entre ambos actores, y en las pocas veces en las que se han comunicado, estas propuestas no han salido a flote de manera efectiva por dificultades de parte y parte. En segundo lugar, el proyecto de los ecoguías no ha sido una opción de trabajo que pueda reemplazar otro tipo de labores, como se ha venido exponiendo. En tercer lugar, no ha habido más capacitaciones y se ha pasado de una intención de inclusión de los habitantes locales como guías a emplearlos como mano de obra para el aseo y la cocina, por lo que queda un poco de lado la labor del ecoguía propuesta.

Casos como los del Parque Nacional Natural Utría y el Parque Nacional Natural Corales del Rosario y San Bernardo expuestos por Rubio et al. (2000) y Durán (2009), respectivamente, muestran cómo se incluye a la población local en proyectos que fomentan usos sustentables de los recursos del entorno, fundamentales para la supervivencia social y ambiental, acompañados de diagnósticos e investigaciones de la mano de los conocimientos locales. Estos autores aseguran que muchos de los declarados parques naturales o áreas protegidas han desconocido la presencia de pobladores locales y sus características socioculturales, quitándoles el control sobre sus territorios y recursos naturales, que son parte de su economía y cultura.

En el caso que presenta Durán (2009), se establecieron proyectos ecoturísticos para incluir a la población luego 
de un periodo de desconocimiento y estigmatización de los pobladores locales y sus usos de los recursos naturales. Por su parte, Rubio et al. (2000) abogan, en buena medida, por superar las disputas que supone la superposición de los territorios de poblaciones locales con áreas de conservación a través de políticas de participación, inclusión y concertación. En Guasca, la idea de incluir a la población en la protección y el manejo de los recursos naturales por medio del trabajo, dentro y fuera de la RBE, hace parte de un ejercicio incipiente de inclusión, mas no de participación efectiva, en el manejo ambiental. Además, su alcance, incidencia y permanencia como proyecto permanente ha sido insuficiente.

Esta participación incipiente implica la subordinación de la población a una entidad externa. Para poder ejercer autonomía sobre su territorio, deben discutir con un actor que si bien posee la propiedad de unos terrenos, no es una habitante del lugar, lo cual es sumamente problemático. Aunque el trabajo es una forma de contacto entre la población y los funcionarios de la FNC, para que haya una participación efectiva, es clave y necesaria la existencia de planes de concertación y toma de decisiones en conjunto. No deja de ser problemático que el ecoturismo sea solo una de la formas de establecer contacto entre áreas protegidas y comunidades y que la participación que se les dé solo sea en el marco de tener acceso a parte (generalmente es muy poca) de los beneficios económicos que genera el ecoturismo, como sucede en el caso de Guasca. Es clave trascender de la relación patrón-empelado y no asumir que la vinculación a actividades ecoturísticas sea una forma total de empoderamiento de 
las comunidades, más bien puede tornarse en coerción, pues al ser empleados, se ven abocados a asumir lo que sus jefes les proponen sin mucha posibilidad de interpelarlo.

En el caso de la RBE, las personas que han trabajado con la FNC, ya sea como concesionarios que compran pastos o empleados directos, tienen mayores posibilidades de diálogo con la ONG y de expresión de sus sugerencias frente al manejo de los recursos ambientales. Con todo, este ejercicio de diálogo está por construirse en la RBE, pues hace falta la institucionalización de espacios de participación y que las opiniones expresadas por estos pobladores tengan mayor peso en las decisiones que se toman en la RBE, es decir, que trascienda de la relación patrón-empelado que impide la participación efectiva, y se vea a las personas, más que como trabajadores, como población que tiene el derecho de ser partícipe activo en la toma de decisiones.

Sin embargo, algunos vecinos del sector consideran positivo que la FNC les haya brindado la oportunidad de trabajar allí, esto es, que haya tenido en cuenta las personas de la vereda. Algunos expresaban que les parecía bueno el trabajo de guías que habían desempeñado allí porque aportaban con lo que sabían y aprendían de la gente que venía de visita a la reserva.

En un artículo titulado "Reimaginar la ecología política: cultura/poder/historia/naturaleza”, Aletta Biersack (2011) traza un recorrido genealógico de la ecología política. Parte de su propuesta consiste en esbozar los intereses actuales de este campo de estudio, siendo uno de ellos la consideración tanto de la agencia como de las determinaciones estructu- 
rales. En medio de los conflictos ambientales, los diferentes actores presentes en ellos toman posiciones, discursos y prácticas que son muestra de su agencia.

Así, los habitantes de Pueblo Viejo no asumen pasivamente los usos propuestos por la FNC sobre las tierras que conforman la reserva (problema que será abordado en el capítulo III), ni tampoco las opciones laborales y actividades realizadas por la FNC. En general, las personas que han trabajado en la RBE como guías consideran que este trabajo les permite aprender sobre la fauna y flora nativa y aportar con sus conocimientos. Aunque están de acuerdo con el pago, reparan sobre la regularidad del trabajo y el hecho de que traigan guías de Bogotá. Ven en este trabajo un ingreso complementario, mas no principal, porque el dinero que aporta, debido a la poca regularidad de esta labor, es muy bajo como para sobrevivir. Un trabajo regular, con condiciones salariales y de contrato estables en la RBE, podría trascender en una opción laboral efectiva para suplir las necesidades de trabajo locales.

Por su parte, esta agencia se hace evidente en las propuestas locales para generar mayores fuentes de trabajo en la RBE. En alguna ocasión, una vecina tuvo la propuesta de vender productos caseros en la RBE para ofrecerlos a los turistas. La propuesta consistía en elaborar yogures caseros y venderlos a los visitantes de la RBE. La vecina propuso esta idea como una oportunidad de generar ingresos extra para su familia. Sin embargo, por diversos factores, entre ellos la dificultad de esta familia para cumplir con el requisito de registro sanitario del producto, la propuesta no se llevó a cabo. Esta 
idea de vender productos a los turistas ha sido recurrente entre los vecinos. Algunos proponen, por ejemplo, la venta de almuerzos por medio del montaje de un restaurante:

Si ellos continúan digamos con su proceso de ecoturismo, pues el trabajo sería en eso. En guías. Qué más. A no ser que en algún momento monten por abiun restaurante bien grande y necesiten empleados. Porque ¿qué más puede? Ah también pueden de pronto algún este de artesanías, y qué sé yo para tanta gente que viene. Eso suele haber en los parques así y en los lugares turísticos. Esto se viene convirtiendo en un lugar turístico. (Entrevista a vecina del sector, 13 de agosto de 2012, cursivas del autor)

En otra entrevista, ante la pregunta de cómo se podría ofrecer más trabajo en la reserva, comentaban:

Pues no sé, a esa reserva le hace falta como un buen restaurante, como una caseta donde vendan golosinas. Pero donde tengamos la oportunidad, digamos, que yo quiero colocar mi negocio y le den a uno la oportunidad de colocarlo. Así toque dar alguna parte a la Fundación, pero que lo dejen trabajar a uno. Porque nosotros propusimos todo eso. Cuando la cabalgata, que para colocar la cabalgata y eso y mi esposo compró los caballos y no, nunca, o sea fue como dos veces nada más y nunca lo volvieron a llamar más. (Entrevista a habitante local, 8 de septiembre de 2012, cursivas del autor) 
Otro tipo de propuestas versan sobre la venta de productos orgánicos y la generación de microempresas:

Acá pueden poner una microempresa de cualquier cosa. Como es una cosa de naturaleza, podían tener una cosa de hortalizas, de todo eso, y ahí había empleo, ahí había venta, por decir algo. Porque son, no van a ser plántulas, hortalizas químicas, sino orgánicas. Entonces imagínese cuánto se está perdiendo ahí. Se podía fundar una cosa de esas. Ahí habría empleo. Sí señor, es que eso, yo no sé si lo pensarán hacer o hasta ahora se está organizando. (Entrevista a vecino del sector, 3 de septiembre de 2012)

Para muchos de ellos, la reserva no puede ofrecer muchos empleos porque, según su percepción, ahí no hay mucho para hacer. En este sentido, la opción que plantean varios vecinos es la creación de nuevas actividades económicas que se articulen al ecoturismo. Estas propuestas expresan un acuerdo de los vecinos por las actividades turísticas desarrolladas en la RBE, pues las reconocen como labores principales que se pueden desarrollar allí, dados los usos de los recursos naturales propuestos por la RBE que impiden otro tipo de actividades.

Durante el trabajo de campo y las entrevistas, las personas no expresaron mayor desacuerdo con este tipo de actividades ecoturísticas que desarrolla la FNC. Con todo, existen algunos reparos y tensiones que versan sobre la manera como se usan los recursos naturales, en especial el suelo, durante estas actividades que se analizarán en el capítulo III. 
Más bien, en cuanto al turismo desarrollado en la RBE, estas opiniones citadas reflejan unas propuestas para mejorarlo en pro de la generación de mayores ingresos y opciones de trabajo para la población local.

Aquí yace el debate sobre los alcances del ecoturismo como propuesta económica viable para las poblaciones aledañas a áreas protegidas y sus implicaciones en la reconfiguración del espacio y la naturaleza. Mientras se cambian los usos de los recursos del entorno y el espacio es definido como zona de conservación privada en donde los elementos biofísicos toman valor económico en sí mismos bajo el discurso de la biodiversidad, se propone el ecoturismo como actividad sostenible que, se supone, está en concordancia con los intereses de la conservación. Sin embargo, esta actividad genera menores ingresos, escasos puestos de trabajo y cambios en las formas de entender y usar el entorno. Además, algunos autores la consideran como una forma de conservación neoliberal, esto es, que se encuentra bajo la lógica de la acumulación y la privatización (Ojeda, 2012).

En Guasca, esta lógica es visible en las diferentes formas de la restricción del uso de los recursos naturales a partir de la declaratoria de un área protegida privada, además de su relación con lógicas de acumulación del sector privado, como dar valor económico a porciones de bosque, obtener pagos por servicios ambientales, cobrar por la siembra y mantenimiento de árboles, entre otros, cuyos beneficios no llegan a la población local. Es un área protegida en la que los actores locales no han tenido participación efectiva, en parte por su condición de ser una propiedad privada. 
Las cabalgatas mencionadas en uno de los fragmentos citados hicieron parte de un proyecto que plantearon unos vecinos del sector que, según ellos, no obtuvo mayor resultado. Aseguraron que el jefe, de ese entonces, de la RBE les había dado el beneplácito para realizar cabalgatas con los turistas desde el sector de El Salitre, punto en el que empieza el ascenso hacia Pueblo Viejo y, por consiguiente, hacia la reserva. La idea consistía en llevar a los turistas a caballo, y no en buses o en carros particulares, como sucede a menudo, por los cinco kilómetros que hay desde el sector de El Salitre hasta Pueblo Viejo.

Estos vecinos comentaron que este servicio funcionó unas pocas veces y que luego la actividad no se volvió a desarrollar, pues la FNC nunca los llamó para ofrecerlo nuevamente. Por consiguiente, tuvieron que vender los caballos que habían adquirido por cuenta propia para el desarrollo del servicio. En una conversación con el jefe actual de la RBE, este comentó que posiblemente esta actividad no se siguió desarrollando "por falta de mercado"; aseguró que se seguía ofreciendo, pero no había demanda. Esto demuestra cómo las condiciones de mercado tienen influencia y se relacionan con las actividades ecoturísticas, el trabajo en la RBE y el uso de los recursos naturales por su parte, las opciones de poner un restaurante y vender comida tienen un componte interesante que se hace visible en la división del trabajo por género en el sector (tabla 1). 


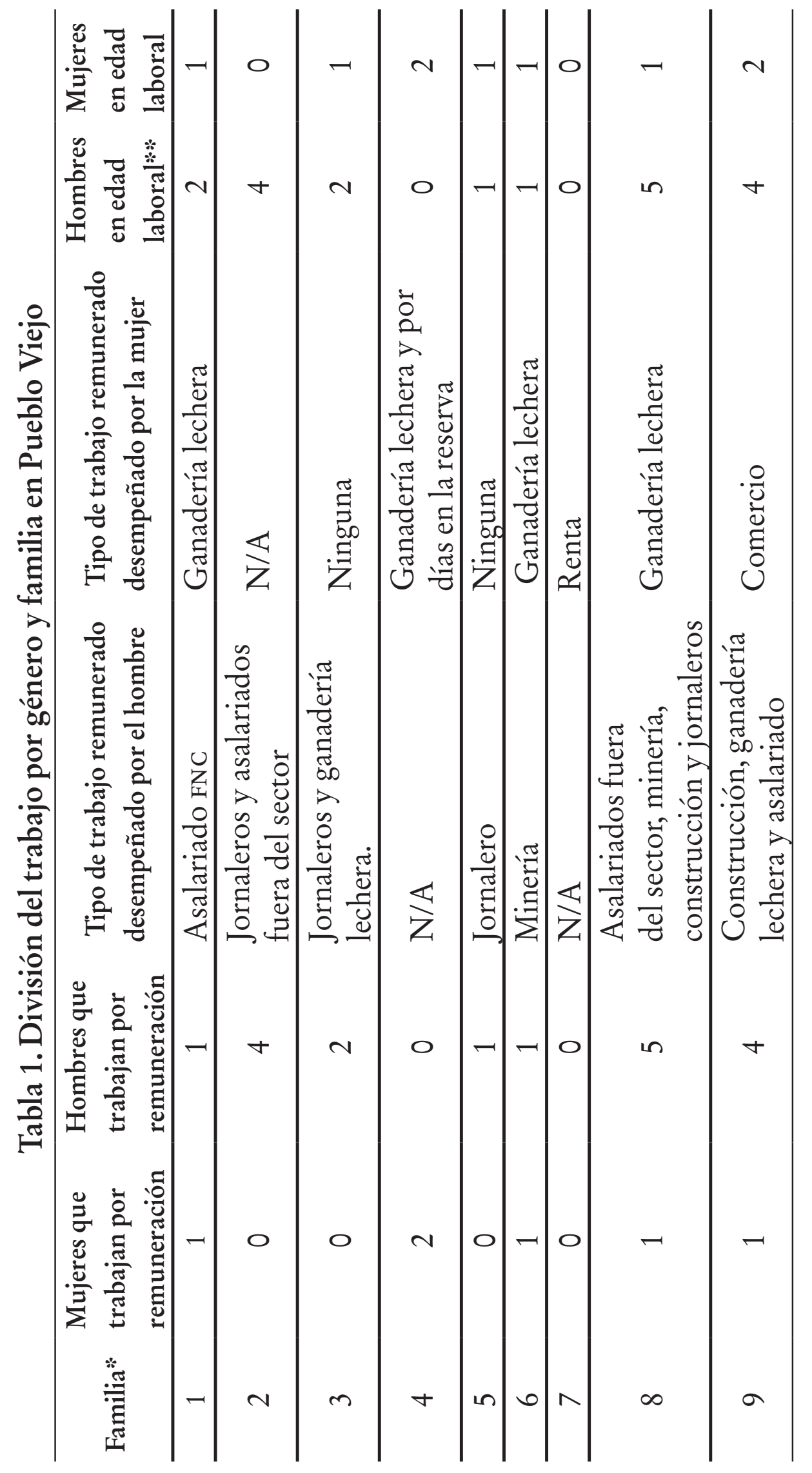


Felipe Rojas Arias

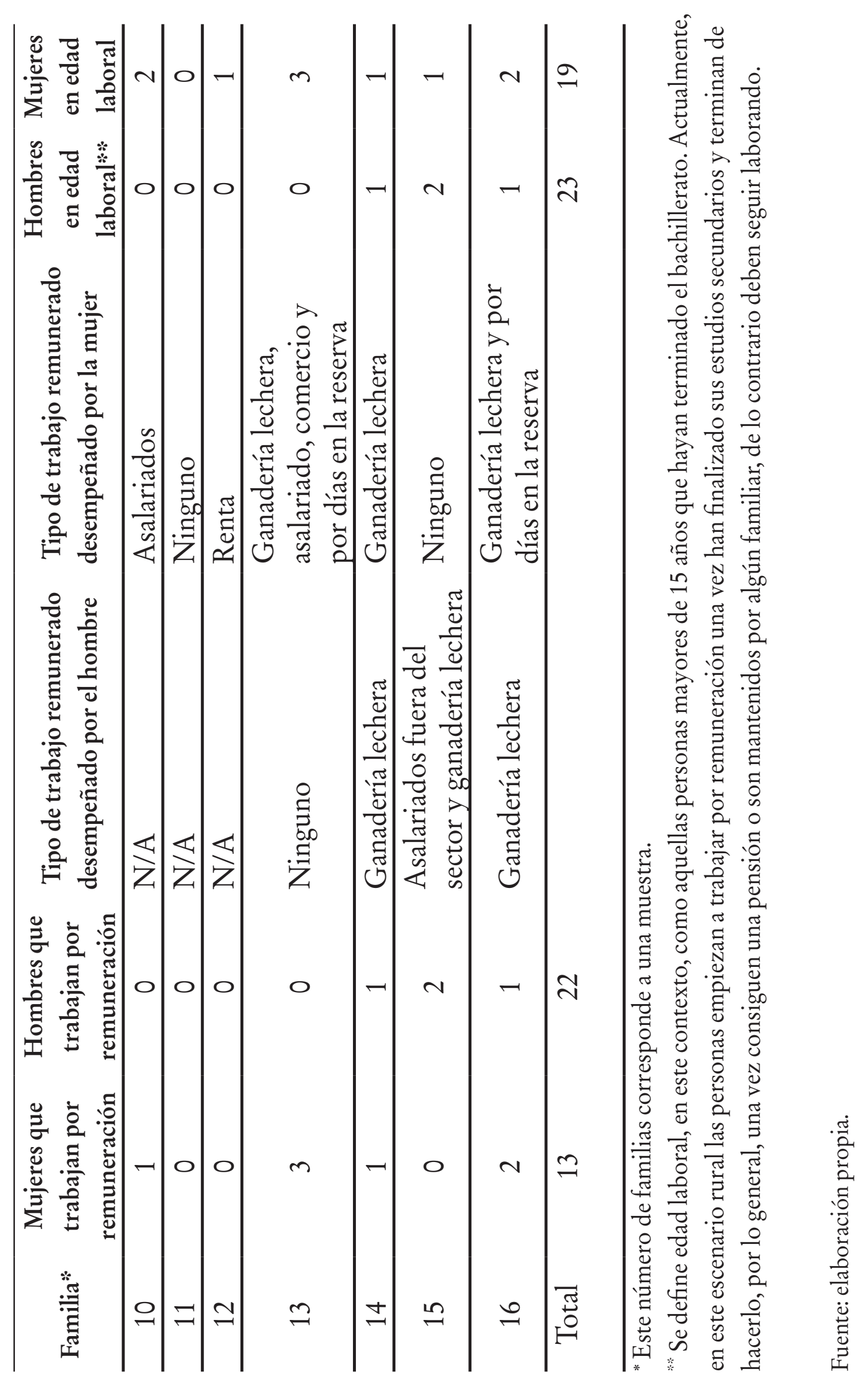


De las 19 mujeres en edad laboral, 13 ejercen alguna labor remunerada. Se hace la salvedad de la obtención de ingresos, pues todas las mujeres se desempeñan en labores y trabajos del hogar no remunerados como cocinar, lavar, limpiar la casa, cuidar a los niños, cuidar animales domésticos para autoconsumo (como gallinas y vacas lecheras) y atender la huerta casera de autoconsumo. Por su parte, de los 23 hombres en edad laboral de las familias de Pueblo Viejo, 22 ejercen algún tipo de labor remunerada. Entre las mujeres que desempeñan alguna labor remunerada, cerca de 10 trabajan en labores de ganadería lechera y 5 en la RBE. Por su parte, de los hombres que trabajan, cerca de 7 se desempeñan en ganadería lechera y solo uno en la RBE.

Es una tendencia en el sector que en los hogares en donde solo trabajan mujeres estas se dediquen a la ganadería lechera, debido a que no es bien visto que laboren como jornaleras en fincas, pues este trabajo es considerado muy pesado para ellas. Incluso en los hatos ganaderos no emplean a las mujeres para las labores de ordeño, pues atender a una gran cantidad de reses es considerado como un trabajo no apto para ellas. Esto se ve reflejado en que las mujeres que trabajan de manera independiente en ganadería lechera no tienen más de 7 vacas.

Si bien hay hombres que practican la ganadería y se dedican a ella, es más común que sea un trabajo de las mujeres, pues se convierte en una opción de vida para ellas a falta de otras alternativas acordes a sus roles de género. Los hombres tienen otras opciones en fincas como jornaleros e, incluso, les resulta más fácil trabajar fuera del sector, pues no tienen 
la obligación cultural de atender el hogar y cuidar a los niños. Las pocas mujeres que son empleadas en fincas lo hacen porque la unidad familiar adquiere un contrato con el dueño del predio para ser sus concertados. El sueldo se le paga al hombre de la casa y las mujeres e hijos son vistos como colaboradores de los hombres en las labores de la finca.

Por esta razón, las mujeres que pretenden trabajar a cambio de una remuneración requieren de un empleo en el sector. Es aquí cuando la FNC y la RBE adquieren relevancia en la división del trabajo por género en Pueblo Viejo. Algunas mujeres del sector consideran, por las razones anteriormente expuestas, que es necesario para ellas un trabajo cerca, que no sea considerado pesado (dado que ejercen demasiadas labores domésticas) y les permita seguir viendo por su hogar e hijos, pues es su labor la reproducción social. Según la tabla 1, de las 6 personas que desempeñan alguna labor con la Fundación, 5 son mujeres. Estas mujeres trabajan por días haciendo labores de aseo, cocina y guianza cuando vienen visitantes a la RBE. Sus labores en la reserva se ajustan culturalmente a las formas de trabajo consideradas femeninas en el sector: no son vistas como pesadas, quedan cerca al lugar de vivienda y tienen que ver con labores del hogar como hacer aseo o cocinar.

Así, las propuestas para generar mayor trabajo en la RBE tienen que ver, en gran medida, con la situación de falta de empleo para las mujeres del sector que se ajuste a sus pautas culturales de trabajo femenino. Otro tipo de estudios han demostrado que las mujeres están ligadas a la esfera doméstica y por eso las labores remuneradas que ejercen están 
muchas veces acordes con esta obligación de atender los oficios del hogar y los roles de género, como por ejemplo la ganadería en pequeña escala para el caso andino (Cavalcanti y da Mota, 2003; Meertens, 2000).

El trabajo en el sector de Pueblo Viejo se encuentra en una situación difícil. Las opciones laborales son escasas, por lo que las personas deben salir a buscar trabajo por fuera del sector. Esto explica la baja tasa de desempleo de la vereda, pues la emigración de población sin empleo ha hecho que se presente una situación de equilibrio entre población en edad laboral y población que trabaja. No obstante, los habitantes locales expresan una opinión desfavorable frente a la oferta y la calidad del empleo en el lugar. La falta de oferta, estabilidad y contratos laborales afectan la situación económica de Pueblo Viejo. Estas opiniones están acompañadas y parten de una añoranza por una época en la que hubo fuentes de empleo con buenas condiciones a nivel de estabilidad, oferta y prestaciones cuando funcionaba la compañía explotadora de cal. La principal actividad en esta región es la ganadería lechera, pues ofrece oportunidades de trabajo sin necesidad de invertir mucho dinero y es una respuesta a la falta de tierras cultivables.

La situación de empleo en Pueblo Viejo tiene relación con el ecoturismo como actividad propia del discurso neoliberal de la conservación ambiental. El neoliberalismo asigna valor económico a los ecosistemas, en este caso el bosque alto andino, que entra en circuitos de mercado, al ser conservado o restaurado por medio de bonos de carbono, o pago por servicios ambientales. Todo esto significa una extensión del 
mercado a nuevas esferas, en este caso la de la conservación ambiental. Son precisamente estas actividades del conservacionismo neoliberal las que generan trabajo en Pueblo Viejo, en particular para la atención de los visitantes que pagan por apreciar y restaurar los ecosistemas y la naturaleza. Esta forma neoliberal de producir el espacio de bosques como una actividad rentable sin necesidad de desmontar, sembrar o extraer directamente ningún mineral o elemento natural, sino dejando "intactos" los bosques, genera formas particulares de trabajo, que en el caso de Guasca no están empleando la mano de obra disponible o respondiendo a las expectativas de la gente.

Adicionalmente, este discurso neoliberal de la conservación ambiental de la mano del mercado interviene en la relación que los pobladores tienen con su entorno no solo en las prácticas, sino en su conceptualización. Nombres científicos y conceptos como el de biodiversidad entran en tensión con formas locales de comprender la naturaleza. Adicionalmente, el ecoturismo promueve nuevas maneras de explotación de los recursos naturales que entran en tensión con las actividades agropecuarias. En consecuencia, el ecoturismo es una de las caras de la política actual de administración de los recursos naturales bajo la lógica ambientalista que produce sujetos, naturaleza, espacios y nuevas labores.

En Guasca, el ecoturismo no ha respondido, como en muchos otros escenarios del mundo presentados en este capítulo, a las necesidades de subsistencia local. En este caso, la situación laboral es preciara, en especial para las mujeres, por lo que las personas ven en la FNC un lugar en el que, 
con algunos ajustes y nuevas propuestas en sus actividades, se pueden ofrecer puestos de trabajo para las personas del sector, en especial para las de género femenino, articuladas al ecoturismo. Sin embargo, muchas de estas propuestas no han sido trasmitidas a la FNC o acogidas por falta de canales de comunicación y debido a la desigualdad de poder de decisión entre las partes.

El empleo digno (de la mano del diálogo y la concertación) de pobladores locales en parques y reservas naturales constituye una opción de inclusión de la población local en el manejo de áreas protegidas que puede generar varias ventajas. Reduce la presión sobre los recursos naturales porque el brindar buenos empleos en labores asociadas a la conservación y las áreas protegidas representa una opción de ingresos sustentable, o por lo menos causante de inferiores daños al ambiente. En segundo lugar, puede llegar a fomentar la participación en su manejo, la escucha de sus opiniones y una alternativa de diálogo con las autoridades y administradores de las áreas protegidas. Finalmente, el círculo de pobreza y deterioro ambiental puede ser roto a partir de la generación de opciones de trabajo y la articulación de usos locales y usos de la conservación que serán objeto de análisis del siguiente capítulo.

Sin embargo, para el caso de la RBE, no se puede hablar de una articulación efectiva de la población en el manejo de la reserva, pues hacen falta espacios de diálogo, así como mejorar la calidad y cantidad de empleos en la RBE. Sin embargo, sigue siendo un problema, como se discutió en el capítulo i, que el derecho y las reglas de manejo sobre los recursos del entorno 
emanen no de la condición de habitantes de estas poblaciones, sino del otorgamiento que les es dado a estas personas por el estado o las organizaciones que hacen sus veces en el manejo ambiental (en este escenario, la FNC).

No deja de ser problemático que sean actores externos los que dictaminen las formas de uso de los recursos naturales y el manejo de áreas protegidas bajo el rol de jefes de la población local, como sucede en el caso del trabajo otorgado por áreas protegidas. En consecuencia, lo que se pone en discusión es la autonomía de gobierno y manejo de los recursos y territorios que ejercen las poblaciones locales a través del trabajo en áreas de conservación. 



\section{Capítulo III \\ Los usos de la tierra en Pueblo Viejo: un mismo suelo, aprovechamientos distintos}

En este capítulo se analizarán los usos de la tierra propuestos y practicados por los habitantes locales y por la FNC, y las tensiones que se derivan de estos aprovechamientos. Este apartado se desarrolla a partir de las discusiones analíticas sobre las formas de manejo de los recursos naturales, las tensiones por el uso de recursos en áreas protegidas y las disputas entre los conocimientos locales y los conocimientos científicos de manejo ambiental.

A partir de las tensiones por el uso de la tierra, se discutirán los modelos de participación y manejo de las áreas protegidas. En general, los vecinos del sector tienen reparos sobre algunas de las formas en que la FNC está usando la tierra al interior de la RBE. Sin embargo, su inconformidad con el manejo de la RBE se manifiesta en críticas que se basan en las maneras como los vecinos entienden los usos de la tierra y sus beneficios. En primer lugar, se presenta una caracterización de los usos de la tierra en Pueblo Viejo y, luego, se exponen y analizan las tensiones, los acuerdos y los desacuerdos frente a su aprovechamiento. Finalmente, se presentan las propuestas de los pobladores frente al uso de la tierra en la RBE. 


\section{Los usos locales de la tierra}

Acorde con la figura 7, los usos de los recursos naturales que hacen las familias cuyas tierras están localizadas en las inmediaciones de la RBE son en su mayoría pecuarios. Estos consisten, en mayor proporción, en bovinos para producción lechera y, en menor medida, en ovinos. De las 14 familias que usan la tierra para el pastoreo de ovinos lecheros, cerca de 10 lo hacen para la venta y el autoconsumo, 3 venden sus pastos para esta actividad y una familia pastorea una vaca lechera para autoconsumo. Las familias del sector dependen en buena medida de la ganadería lechera porque esta actividad representa una de las principales fuentes de ingresos a partir de su venta a intermediarios que comercian con las pasteurizadoras. Como se muestra en la figura 4 del capítulo II, este tipo de ganadería es la principal actividad laboral de la localidad. Este aprovechamiento supone unos usos particulares de la tierra, como el pastoreo extensivo, el cuidado de las pasturas y potreros, entre otros, y unas relaciones económicas, como la venta de pastos entre los vecinos del sector.

La ganadería lechera requiere principalmente de buenos pastos y amplias zonas para pastar; entre más cercanos esos pastos a la vivienda del propietario del ganado mejor, debido a que se disminuye el tiempo y esfuerzo en el desplazamiento para efectuar el ordeño y el trasporte de las cantinas con la leche hasta su hogar, en donde, por lo general, los intermediarios recogen el producto. 
Figura 7. Usos de la tierra en Pueblo Viejo

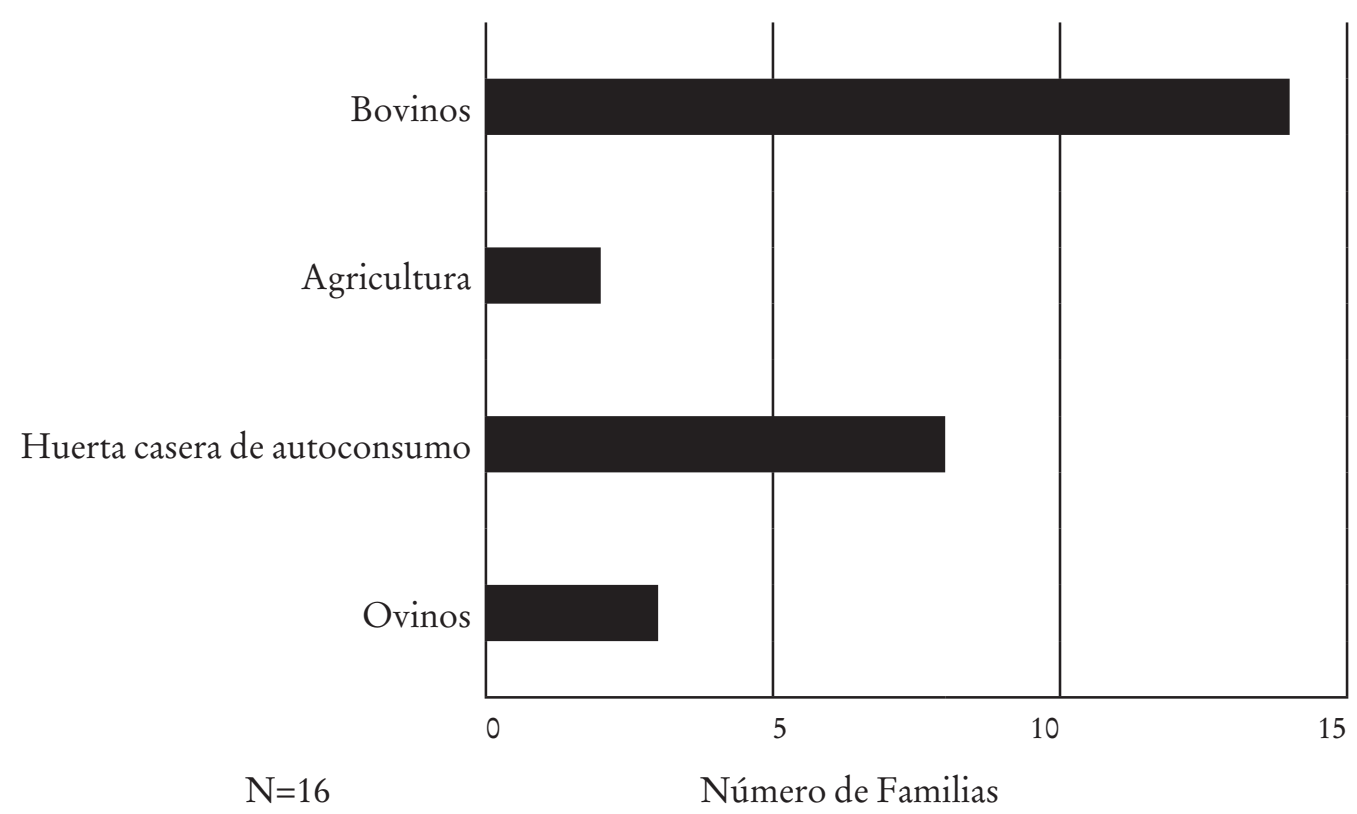

Fuente: elaboración propia.

En esta actividad los pastos se compran en una unidad de medida denominada "pastada", que equivale al tamaño del potrero. Entre más grande sea el potrero, mayor extensión para pastoreo y, por consiguiente, mayor el valor de la pastada. La altura del pasto en el potrero no influye en el valor de la pastada porque este se compra solo cuando ha alcanzado el crecimiento necesario para pastoreo lechero; si es muy bajo o muy alto no se compra porque disminuye la producción de leche. Por consiguiente, esta unidad de medida local equivale al desyerbe que hace el ganado de todo un potrero en un tiempo determinado. Una vez esto sucede, el propietario de las vacas paga al dueño del potrero el valor que hayan acordado por la pastada.

Por lo general, los ganaderos y vendedores de pasto tienen un cálculo aproximado del tiempo de desyerbe, aunque no se vende por tiempo, sino por cantidad de pasto. 
Vender pasto es diferente a un contrato de arrendamiento. La persona que compra los pastos no puede efectuar mejoras sobre los predios, simplemente introduce su ganado por un tiempo determinado y paga lo acordado al dueño del potrero. En este intercambio de un bien (el pasto), el comprador no tiene más derechos sobre el predio que el usufructo del agua y sus pastos.

Los propietarios de los predios se deben encargar, entonces, de mantener unos buenos pastos para la venta porque estos representan para ellos un cultivo que venden a los ganaderos. Sin embargo, hay casos en los que el ganadero controla plagas y abona para mejorar el pasto durante el tiempo que pasta su ganado en un determinado predio. El que compra el pasto tiene derecho a alimentar a su ganado hasta que se agote todo el corte. Con todo, es común que se calcule, de acuerdo con la cantidad de ganado y el tamaño del potrero, el tiempo que demorará en agotar el corte (desyerbe total). Adicional al pasto y al agua, la ganadería lechera requiere que las vacas tengan acceso a medicamentos, sal y concentrados, así como la aplicación de abonos y el control de plagas en los pastos.

Otro uso de la tierra en esta región consiste en las huertas de autoconsumo, cultivos, en su mayoría hortícolas, sembrados en pequeños terrenos cercanos a la casa de cada familia. Algunas de estas huertas de autoconsumo son cuidadas y cultivadas por cada familia o en compañía con otros familiares habitantes del sector. En este tipo de huertas sembradas en compañía no median relaciones monetarias sobre el intercambio de productos. 
En el trabajo de campo se constató que en algunos casos las semillas, las tierras, el trabajo y los insumos necesarios para cuidar la huerta eran aportados por parientes que cultivan en conjunto para obtener productos de autoconsumo, lo que deja ver formas no capitalistas de comercio. En consecuencia, la huerta casera no se destina para el mercado, aunque entra en circuitos de intercambio no sometidos a precios ni valores monetarios, sino que son mediados por las relaciones de parentesco de las personas que la siembran. Una vez se cosechan los productos, se reparten entre los miembros de la compañía sin que medien relaciones de tipo monetario.

Las huertas de autoconsumo utilizan un bajo porcentaje de productos químicos para abonar, proteger y fertilizar las cementeras, pues al no ser para la venta, no están mediadas por intereses de incrementar su productividad, tamaño y ganancias. Además, como son de autoconsumo, no existe la posibilidad de recuperar lo invertido en agroquímicos. Los productos que se siembran en este tipo de cultivos son hortícolas: predominan las habas, la cebolla en rama y el repollo. Sin embargo, la papa es otro producto que no escasea en las huertas caseras de Pueblo Viejo. Algunas familias también usan la huerta para sembrar hierbas aromáticas como el toronjil, la caléndula, la ruda, la limonaria, entre otras, y plantas ornamentales como las astromelias.

En Pueblo Viejo la agricultura como actividad económica es muy escasa por la falta de tierras, no solo por su aptitud, sino por el uso que le dan sus propietarios. En la época en que funcionaba la mina, la compañía explotadora de cal tenía 
algunos cultivos de papa y trigo destinados al comercio y el autoconsumo local trabajados por obreros de la empresa. En la actualidad, el único cultivo comercial de papa que hay no es sembrado por las familias del sector, sino por un arrendatario de fuera de Pueblo Viejo.

Hoy en día existe la RBE en las mismas tierras donde la compañía explotadora de cal practicaba la minería y algunas actividades agropecuarias, y que posteriormente (entre 1992, cierre de la mina, y 2007, constitución de la RBE) fueron aprovechadas por un arrendatario del señor Hoeck en ganadería y agricultura. En la reserva no arriendan los potreros ni permiten el desarrollo de actividades agrícolas de tipo comercial. La FNC está desarrollando en una pequeña porción de la RBE un banco de biodiversidad de papa y tiene junto al centro de visitantes una huerta orgánica de hortalizas. El resto de sus tierras están dedicadas a los procesos de restauración ecológica, ecoturismo, conservación del bosque y venta de pastadas.

\section{Tensiones por el uso de la tierra en la Reserva Biológica Encenillo}

Las poblaciones aledañas a las áreas de conservación formalmente establecidas ven restringidos el acceso y el uso de los recursos que en ellas se encuentran (Pinilla, 2004). Acerca de los parques nacionales en Sudamérica, Amend y Amend (1992, p. 463) sostienen que sus principales fuentes de problemas son los "conflictos con la población por actividades agropecuarias, ocupaciones ilegales y utilización de recursos del área protegida”. Algunos otros autores definen el 
problema en términos de la tensión entre la protección de los recursos naturales y su uso para la subsistencia humana (Villa, 1992), y la autonomía en el manejo de sus territorios y sus recursos (Pinilla, 2004; Peluso, 2005). Por ejemplo, existen casos como los del parque nacional Amboró en Bolivia, en donde se delimitaron áreas exclusivas de conservación, o de línea roja, en las cuales se restringían todo tipo actividades de explotación y producción para las poblaciones locales, lo cual implicó la racionalización de las actividades desarrolladas por los habitantes del parque (Moscoso, 1992).

En el caso de la RBE, la principal tensión que se presenta entre la FNC y los pobladores locales radica en las percepciones distintas frente al uso de la tierra en actividades agropecuarias y conservacionistas. En este sentido, se propone un análisis antropológico, cuyo interés es el estudio etnográfico de las formas de representación de los recursos naturales y cómo ello, en medio de procesos políticos, media en su aprovechamiento y genera tensiones.

La FNC ha permitido a la población local el uso de estas tierras para la ganadería. Antes de su constitución, el arrendatario del señor Hoeck no vendía pastaje y subarrendaba muy poca de la tierra que tenía en arriendo, pues él era quien utilizaba los potreros para su propio hato y agricultura:

Felipe Rojas: ¿Y de pronto cuando don Pedro ${ }^{14}$ administraba eso había más trabajo que actualmente?

14 Nombre cambiado. 
-Habitante local: Mmm, pues no, no y menos la gente podía vivir porque no había los arriendos como los hay ahorita. Ahoritica cuando cogió la Fundación eso pues sí tienen a la gente ahí, les han arrendado [vendido pasto] a cada uno dos, tres porteritos para que mantengan sus tres, cuatro vaquitas. Y antes no lo había porque cuando estaba don Pedro como administrador esto no dejaba, a nadie le vendía una pastada para nada. Sí.

-FR: ¿Y él entonces cómo hacía?

-HL: No, él solo mantenía todo, solo mantenía él.

-FR: De él, su ganado y su...

-HL: Sí él, todo, eso no dejaba mantener a nadie, a nadie nos vendía [pasto] decir "deme pastaje para una res, para unos dos meses”, no, nunca lo hizo. En cambio ahorita cambió mucho porque la persona que está hecho a cargo a eso [a las tierras de la RBE] está vendiendo los pastos, les deja para la mantención de sus tres, cuatro vaquitas que tiene la gente por ahí. (Entrevista a habitante local, 20 de agosto de 2012)

La RBE comprende aproximadamente unas 60 hectáreas de potreros y unas 135 hectáreas de bosque primario y secundario (FNC, 2008a). Actualmente, estas hectáreas de potreros están siendo utilizadas para restauración ecológica y ganadería extensiva. La FNC vende a un buen número de pobladores locales pastadas para el pastoreo de su ganado lechero. Esta ganadería, si bien es extensiva, implica el levantamiento de cercos que impiden el paso del ganado hacia el bosque y las fuentes hídricas. Por su parte, Corpoguavio, (Corporación 
autónoma regional del Guavio $)^{15}$ como autoridad ambiental, ha exhortado por medio de sus visitas a la población local sobre el manejo cuidadoso de las fuentes hídricas para ganadería, es decir, para evitar que el ganado paste cerca de ellas, pues compacta el suelo con sus cascos y contamina las fuentes acuíferas.

En este sentido, la FNC ha hecho una apuesta por brindar a la población local opciones para el desarrollo de sus actividades ganaderas. No ha descartado del todo este tipo de prácticas, aunque pretende que se desarrollen de manera controlada para evitar daños ambientales:

-Felipe Rojas: ¿Bueno y entonces, en ese sentido las actividades que ahora se desarrollan a nivel productivo ahí [en la $\mathrm{RBE}$ ], la principal que yo he hecho en mis observaciones es la ganadería? [Carlos Castillo: correcto]. ¿En qué consiste esa ganadería, es tipo silvopastoril o de qué tipo es?

-CC: Digamos que es predominantemente extensiva, digamos si lo miramos desde el punto de vista cuantitativo. A lo que se quiere llegar, ese es el proceso en el que estamos trabajando, es a que integralmente se le dé un manejo sostenible donde, dentro del manejo sostenible, caben los sistemas silvopastoriles, pero caben otras cosas: es el adecuado manejo del recurso hídrico, un control de plagas evitando el uso de moléculas sintéticas que causen contaminación y

15 La relación entre Corpoguavio y la FNC tiene que ver con el apoyo que la Corporación brinda a la FNC en cuanto a la restauración ecológica. Hasta donde se averiguó en campo, Corpoguavio ha pagado la siembra y el mantenimiento de árboles al interior de la RBE. 
depredación. En fin, es todo un cambio en el cual estamos, digamos, como enfocados y es un proceso al cual estamos dando como comienzo. O sea no es un proceso que esté ya establecido, pero conceptualmente sí tenemos claro qué es lo que queremos hacer en esa dirección. O sea que digamos que la visión de las áreas productivas a mediano plazo, digamos dos, tres años es que se esté manejando de manera sostenible. Es decir minimizando el uso de agroquímicos, las pasturas que sean productivas, que estén generando el propósito productivo de una manera rentable para quienes lo están ejerciendo, sea como productores de leche o productores de carne, y de una manera que no comprometa negativamente, o impacte negativamente el recurso agua, el recurso suelo principalmente. (Entrevista a Carlos Castillo, jefe de la RBE, 18 de enero de 2013)

En la RBE sus funcionarios están tratando de articular algunas de las prácticas de uso de la tierra a nivel local con los usos de la conservación, lo que sugiere modificaciones en ambos sentidos. Tanto las formas productivas locales son modificadas como las ideas del conservacionismo estricto excluido de actividades agropecuarias. Esto quiere decir, en pocas palabras, la conservación de ciertos sistemas productivos propios de esta región, pero modificados según unos criterios particulares de sostenibilidad y, a la vez, la transformación de los paradigmas de conservación ambiental a la luz de las formas locales de producción. Discursos globales ambientales toman lugar en escenarios como Pueblo Viejo y, a partir de procesos políticos, económicos y culturales a 
nivel local, dan pie para trasformaciones en las formas locales de aprovechamiento de la tierra, negociaciones, disputas y cambios en los mismos discursos ambientales.

La articulación de los usos locales y los conservacionistas que se ha dado hasta el momento en la RBE ha consistido en las concesiones de aprovechamiento pecuario de la tierra, que no han introducido mayores cambios en la ganadería, a excepción de la mengua de los pastos debido a los procesos de restauración ecológica y la delimitación de las zonas de pastaje para evitar daños a las fuentes hídricas. Por su parte, los paradigmas de la conservación se han modificado, en tanto, en la RBE se incluyen actividades pecuarias. No solo se trata, entonces, de un cambio en una sola dirección, pues de la negociación entre usos de los recursos naturales locales y los usos de la conservación ambiental devienen modificaciones en ambas formas de aprovechamiento.

Desde una perspectiva de manejo participativo de los recursos naturales (CBNRM), se propone articular los usos "tradicionales" con los conservacionistas. Con todo, una de las principales críticas a este modelo ha sido la construcción de lo que es "tradicional". No se privilegian sino unos aspectos que son útiles al conservacionismo o que se ajustan al CBNRM y se pasan por alto otras formas de uso y conocimiento. Además, aquellos actores que aplican el modelo son los que gozan del poder para construir las ideas de lo "tradicional" desde posiciones esenciales y antagónicas: en algunos casos, lo tradicional es visto como ecológico y en otras como depredador y destructor. Así, se elaboran imágenes preconcebidas sobre lo local que muchas veces imposibilitan un diálogo 
con los conocimientos y las prácticas de las comunidades. El asunto se agrava cuando la población es considerada étnica o no. Para el caso de Guasca, su condición de campesinos es un factor que juega en contra, pues en las políticas multiculturales se excluye al campesinado. Ante la pregunta por las estrategias de inclusión de la población local en el plan de manejo de la reserva, el jefe de la RBE respondió:

Entonces digamos que hay segmentos de población, están digamos en una línea los arrendatarios [concesionarios], entonces con ellos estamos en un proceso de interacción que nos conduzca a que se adopten las prácticas de producción sostenible. Estála población infantil que se quiere persuadir al Colegio del Carmen y todo esto a que en sus programas de ciencias y en sus PRAE (Propuestas ambientales educativas), que haya cada vez mayor acercamiento de la población infantil, juvenil, hacia lo que ofrece la reserva, hacia el potencial de educación ambiental que ofrece la reserva. También para generar digamos apropiación de la población. Que sientan que eso no es que es una reserva allí, sino que es una reserva, nuestra reserva, que esto tiene una importancia y un impacto para la región, para sus propias vidas. Porque en la medida en que allá se esté conservando, en la medida en que ya se esté produciendo agua, pues ellos que viven ahí abajo, pues van a poder disfrutar y satisfacer sus necesidades básicas de una manera, digamos, adecuada. (Entrevista a Carlos Castillo, jefe de la RBE, 18 de enero de 2013. Cursivas del autor) 
Esta cita sugiere parte de la idea que la FNC tiene sobre la participación ambiental local. Como lo expone el jefe de la RBE, en el fragmento citado, la concesión sobre el uso de recursos naturales puede ser un mecanismo para fomentar la participación en el manejo de esta área protegida. No obstante, es muy interesante la forma en la que se entiende la participación, pues no solo se habla del trabajo, sino también de la educación ambiental y apropiación de la RBE por parte de la población. Para el jefe de la RBE, la inclusión de los habitantes se relaciona con interacciones en las que la FNC eduque ambientalmente a estas poblaciones a favor de los intereses de conservación de la FNC. Es una inclusión en la que los pobladores son sujetos que requieren ser intervenidos y concientizados en sus prácticas y formas de pensar, mas no entendidos como individuos que pueden aportar con sus conocimientos, intereses y necesidades al manejo de la RBE.

En el desarrollo de la entrevista, se le preguntó al jefe de la RBE si era posible que se dieran espacios de diálogo con la población local para que expresaran sus propuestas e inquietudes frente a la RBE, a lo que respondió que efectivamente estos se darían en el corto plazo. Con todo, estos espacios son entendidos por el jefe de la RBE como interacciones que permitan generar cambios en las formas de uso de los recursos ambientales locales, es decir, sin tener en cuenta lo que podría aportar la población, sino asumiendo que sus prácticas deben ser modificadas. Este proceso educativo, además, conduciría a que la población "entendiera" la importancia de la reserva para sus vidas, es decir, que se "apropiara de ella” como 
espacio que le presta servicios ambientales, mas no como territorio en el que tiene capacidad de decisión.

Por el momento, gran parte de la apropiación que la población ha hecho de la RBE ha sido a través de las concesiones. Si bien la venta de pastadas a la población no consiste en brindar empleos de manera directa, como se discutió en el capítulo anterior, sí implica que las personas puedan desenvolverse en una actividad laboral que les representa ingresos y uso de los recursos naturales de la reserva. Existe una relación directamente proporcional entre venta de pastos, empleo e ingresos. Siendo la ganadería la principal actividad laboral del sector, la población local depende de la venta de pastos para sustentar su economía. A mayor venta de pastos, mayores posibilidades de empleo en ganadería e ingresos para las familias de Pueblo Viejo.

Por esta razón, el papel de la FNC es clave para la economía de esta localidad no solo por su potencial para la generación de empleos directos, sino que, por su condición de tenencia de una buena cantidad de pasturas, está en la capacidad de brindar otro tipo de opciones laborales a la población. El régimen de tenencia, acceso y propiedad sobre la tierra que reposa sobre las áreas protegidas, es un factor que les implica un papel clave en las economías locales. Cuando los pobladores no tienen suficiente cantidad de tierras para sostener su economía, estas zonas de protección ambiental, por su extensión y riqueza en recursos naturales, pueden llegar a ser indispensables para la subsistencia local. Es allí donde un manejo y acceso participativo a los recursos de las áreas protegidas es fundamental para la vida de los habitantes locales. 
Una de las fuentes de tensión por el uso de la tierra a nivel local ocurre por la diferenciación que hace la FNC entre los procesos de "restauración ecológica", definidos por la Fundación como la siembra de especies nativas que cumplen con funciones dentro del ecosistema, a diferencia de la "reforestación", que significa la simple siembra sin ajustarse a los sistemas ecológicos (FNC, 2008b). La tensión consiste, específicamente, en que la siembra de otro tipo de especies que no se ajustan al ecosistema, como por ejemplo frutales, que es una propuesta de algunos habitantes, puede ser una opción de usos de la tierra que traería beneficios laborales a la población, pero sin concordar con los procesos de restauración ecológica.

Adicionalmente, algunos vecinos proponen el aprovechamiento de las tierras de la RBE en cultivos (los cuales dentro de la lógica local hacen parte de la naturaleza, véase capítulo i) que, acorde con el concepto de restauración ecológica, no cumplen con una función dentro de ese ecosistema alto andino, por lo que pueden no ser admitidos. Estas tensiones tienen como base el cambio de los usos mineros y agropecuarios por los usos conservacionistas y los beneficios que ciertos aprovechamientos pueden generar:

-Vecina: Claro que el beneficio que traía la mina, pues sí había harto trabajo, pero ahorita mismo ya no porque como, pues no dejan, no dejan sembrar cultivos de papa, no dejan nada, entonces solamente ehh la gente que llega [los turistas de la RBE] se dedican es a sembrar árboles. Y entonces lo de antes, lo del trabajo de la mina era sí mejor 
porque cultivaban papa y todo y ahorita mismo, pues no dejan cultivar papa, ni nada.

-Felipe Rojas: ¿O sea, quiénes no dejan, los de la Fundación?

-V: Sí, los de la Fundación. Yo creo, sí ellos. Ya no dejan, los de la reserva ya no dejan esos cultivos de papa, no dejan nada porque donde sembraban la papa eso todo están sembrando árboles. Solo árboles. (Entrevista a vecina del sector, 2 de septiembre de 2012)

Muchos de los pobladores locales identifican que uno de los principales usos que la FNC está haciendo de la tierra es la siembra de árboles. Dentro de las actividades que adelanta la FNC en la RBE, se encuentra el desarrollo de eventos recreativos con empresas privadas como caminatas por los senderos de la reserva, desayunos, almuerzos y fiestas de fin de año.

En casi todas estas actividades recreativas las empresas privadas compran a la FNC y siembran árboles bajo la orientación de los funcionarios de esta ONG. Así es que empresas privadas, Corpoguavio y algunas universidades tienen hectáreas de bosque sembradas en la RBE. Las entidades privadas y personas naturales tienen la posibilidad de deducir la inversión hecha en la hectárea sembrada (el costo es de 50.000 por hectárea anual para siembra y mantenimiento) $y$ en su fiesta de fin de año o evento empresarial (realizado en la RBE) de su impuesto de renta en un $125 \%$ por compensación de huella de carbono e impacto ambiental, acorde con el artículo 12, de la Ley 663 de 2000. Todo este trámite 
se hace por medio de un certificado de donación expedido por la FNC que las personas naturales y jurídicas presentan ante la Dirección de Impuestos para realizar la deducción.

Este tipo de prácticas hacen parte de la introducción de la naturaleza conservada en lógicas de mercado en donde los ecosistemas toman valor económico en sí mismos. En las lógicas ambientales del capital, la naturaleza y sus recursos han trascendido en bienes que para comercializarse, deben dejarse intactos. Los bonos de carbono y el ecoturismo son formas de consumo de la naturaleza construida como prístina.

Otra forma de producir este ambiente "natural" se encuentra en los procesos de restauración ecológica que propenden por restituir el bosque emulando y acelerando el "proceso natural” de reconstitución ecosistémica. Estos procesos en Guasca están atravesados por la economía de mercado, pues las empresas pagan por el desarrollo de la restauración, mitigación de cambio climático y huella de carbono, que, a su vez, generan ingresos a la FNC y financian el mantenimiento de la RBE. Estos procesos tienen que ver con nuevas formas de consumo y la extensión del mercado hacia nuevos bienes y servicios, en este caso relacionados con el cuidado ambiental.

Durante el desarrollo del trabajo de campo, se apreció que diversas empresas venían a la RBE y sus empleados sembraban árboles en su interior. También se constató la existencia de zonas de bosque sembradas bajo el patrocinio de empresas o actores privados (figura 8) que pagaron por su siembra y mantenimiento. Todo esto sugiere que el cuidado de la naturaleza es otra forma de extensión del mercado y 
una actividad descentrada de la acción pública, una forma neoliberal de proteger y producir la naturaleza. En esta lógica neoliberal, el bosque es producido como parcelas privadas que generan riqueza y por medio de las cuales las empresas cumplen requisitos de responsabilidad social empresarial.

Figura 8. Zonas restauradas bajo el patrocinio de actores privados, en este caso universidad que patrocina la siembra de árboles

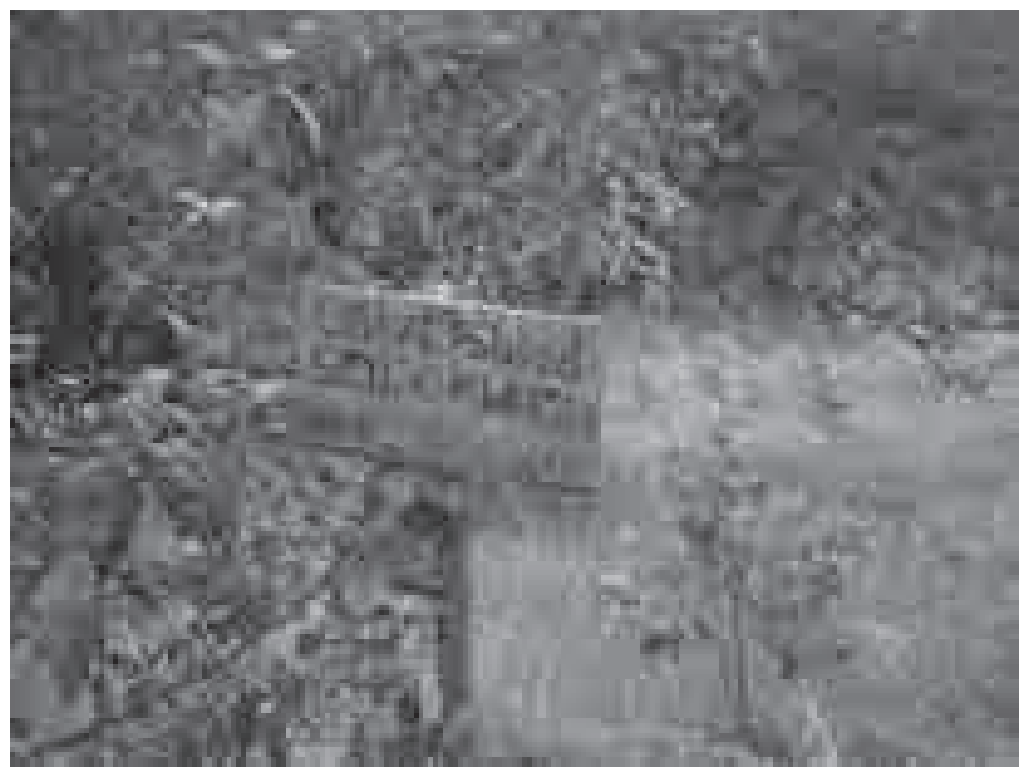

Fuente: Felipe Rojas, 2012.

En medio de un proceso denominado "gobernanza ambiental multitarea", Agrawal y Lemos (2007) definen una forma de manejo ambiental que involucra al estado, las comunidades y el mercado. Este giro de un gobierno exclusivamente estatal a uno descentralizado tiene que ver con el neoliberalismo que implica que el estado ceda parte de sus funciones al sector privado. El caso de la RBE es un ejemplo claro al respecto. Gran parte de la financiación para el mantenimiento de la RBE proviene del mercado que compra 
servicios ambientales por compensación de huella de carbono, que a su vez son incentivados dentro de la política estatal a partir de la deducción fiscal. El estado "protege” al ambiente indirectamente a través de organizaciones privadas y el mercado. Por su parte, los vecinos de Pueblo Viejo son vinculados como compradores de servicios ambientales (pastos) en la RBE como otro mecanismo de financiación del área protegida. En este sentido, en una conversación el señor Hendrik Hoeck comentó que las áreas productivas de la RBE tienen como finalidad ser una fuente de financiación de la reserva a través de las concesiones de venta de pastos a los pobladores locales u otro tipo de actividades. Esta misma forma de financiación de la reserva la dio a conocer el jefe de la RBE en la entrevista que se le hizo.

Existen serias críticas a este modelo de manejo ambiental de la mano del mercado, muchas de las cuales versan sobre la privatización del ambiente y sus recursos. Este modelo se conoce como pago por servicios ambientales (PSA), cuya finalidad consiste en la compensación del daño a los ecosistemas por medio de contribuciones a programas de restauración ecológica y protección ambiental.

La sola mención de pago sugiere que los recursos naturales y sus "servicios" (palabra muy cuestionable por lo demás) son vendidos y comprados, es decir, tienen dueños. Algunos autores consideran estos mecanismos como formas de privatización del ambiente y sus funciones en el marco de la extensión del mercado (Bravo, 2012). Si bien muchas de las entidades que se encargan de proteger el ambiente (como la FNC) son sin ánimo de lucro, parte 
de los mecanismos por medio de los cuales cubren los altos costos de la conservación provienen del mercado. Por otro lado, se cuestiona que los PSA le ponen un precio a la naturaleza y desconocen los valores culturales, territoriales y simbólicos que esta tiene para las poblaciones locales (Bravo, 2012; Rojas, 2012).

En consecuencia, la economía de mercado ambiental irrumpe en los escenarios locales a través del conservacionismo y se convierte en una estrategia de financiamiento de los propósitos de la protección del entorno. La restauración ecológica debe entenderse entonces como una práctica económica y política global que genera cambios en los usos de los recursos ambientales a escala local, al asignar valores monetarios a la naturaleza prístina, y a las prácticas asociadas a su cuidado, y proponer conceptos ajenos a las formas locales de entender y usar la naturaleza como el de biodiversidad. Estos procesos de comercialización de bienes ambientales hacen de la naturaleza un elemento compatible con la rentabilidad y la acumulación del capital (O’Connor, 2003).

La siembra constante de árboles ha sido una fuente de preocupación entre algunos de los pobladores locales, pues saben lo que ello puede llegar a significar en cuanto a los potreros:

En el modo que siembran árboles, siembran y siembran árboles y entonces ya pues con el tiempo se forma como una montaña, como puede que sea un buen beneficio, sí, pero de todas maneras, donde eran buenos potreros, pues da como pesar. Sí, por unas partes es bueno ¿̇ierto?, pero 
entonces por unas partes ya se viene formando como mucho, mucha montaña [...]. (Entrevista a habitante local, 27 de agosto de 2012)

El hecho de que acaben los potreros implica que las personas que se están beneficiando por la venta de pastos que hace la FNC carezcan de sitios en donde pastar su ganado:

-Felipe Rojas: ¿Pero tal vez en un tiempo se vayan a acabar los potreros de pronto al ritmo que ellos están reforestando?

-Vecina: sí, al paso que van sí.

-FR: ¿Y ahí qué sucedería con, por ejemplo, con todas las personas que tienen ganado y les compran los pastos? -Vecina: ahí sí ya nos toca vender y buscar otra forma de trabajo. (Entrevista a habitante local, 8 de septiembre de 2012)

Otro vecino comentaba al respecto:

-Felipe Rojas: ¿Y qué pasaría si eventualmente esos potreros se terminaran, qué pasaría con la gente que está trabajando ahí actualmente pues con sus vaquitas?

-Vecino de Pueblo Viejo: Ah, no y ahí sí ya grave porque van sacándolos. Claro ya los van sacando, ya quedan ahí sin mantención, sin potreros de donde puedan mantener ni nada. Porque como eso es lo que quieren es hacer eso, de tener todo es pero solo bosque, bosque nativo. 
-FR: ¿Y considera usted que ese es de pronto el mejor uso que se le puede dar a esas tierras?

-VPV: Pues, por parte de estar, digamos de haber buenos bosques, buenos por evitar erosiones, por todas esas cosas, pues sí, serviría, pero por otras no porque de todas maneras la gente está quedando sin dónde mantener ni nada. Por decir por las aguas, pa' todo sí pues sirve, porque los bosques eso sirven de mucho, pero para la gente que tienen por ahí su ganado eso sí grave porque ya los van arrumando a sacarlos de una.

-FR: Y en cuanto a trabajo también porque...

-VPV: Pues de lógica porque si no tienen dónde mantener sus vacas, o algo, que muchos venden ahí sus diez, quince, veinte litricos de leche, pues ahí tienen para la mantención diaria. Y si se acaba eso, pues ahí quedan graves. (Entrevista a habitante local, 20 de agosto de 2012)

Uno de los principales problemas con el uso de los recursos en áreas protegidas consiste en la tensión constante entre conservación y subsistencia económica de la población local (Hernández et al., 2005). Los fragmentos de entrevista citados anteriormente expresan esta tensión, pues por una parte se ve con buenos ojos el que siembren, en tanto mejora las aguas y evita la erosión de los terrenos, pero, por el otro, puede que la restauración de todos los potreros afecte la economía de la mayoría de familias del sector que se dedican a la ganadería. Por otra parte, el problema por el uso de los recursos naturales tiene un matiz simbólico en las representaciones de la naturaleza como “monte” y “montaña”. 
El reparo sobre la siembra de árboles no consiste solamente en las dificultades económicas que acarrearía, sino en el crecimiento de una forma de naturaleza que no debe extenderse, "la montaña”, como se analizó en el capítulo I. En algunos casos, esta tensión se ve expresada en la visión de algunos vecinos de la incompatibilidad de estos dos usos (ganaderos y conservacionistas) de la tierra:

Que donde siembren los árboles sí ya no se puede, por decir algo, sembrar pasto, tener ganado. Porque si se tiene ganado no se siembran árboles, cómo le digo yo, dos cosas no se pueden hacer porque el ganado daña los árboles o el ganado no come igual porque el pasto debajo de los árboles ya no va a producir igual. Para producir, para tener ganado hay que tener el potrero libre y para tener árboles hay que tener el potrero destinado para árboles. (Entrevista a poblador local, 3 de septiembre de 2012)

En otra entrevista comentaban:

Pero en cuanto a lo del ganadito, pues nos están quitando beneficios porque sembrando árboles no dejan meter ganado entre los árboles. Y entre más más, porque dicen que van a seguir sembrando más árboles, entonces ya, con el tiempo, pues ya. Por decir nosotros que tenemos, pues no es mucho ganado, pero ya nos toca venderlo porque no hay en dónde mantenerlos. (Entrevista a pobladora local, 6 de diciembre de 2012) 
Estas visiones contrastan con las apreciaciones del jefe de la reserva, quien asegura lo siguiente:

-Felipe Rojas: ¿Bueno y en ese sentido ustedes piensan restaurar todas las hectáreas de potreros que hay al interior? -Carlos Castillo: No. Digamos que en este momento es un tema como de discusión interna. Pero, digamos, la reserva como está planteada actualmente contempla la existencia de áreas productivas porque actualmente sostener una reserva es muy costoso y se requieren recursos y una fuente de recursos puede ser el uso sostenible de esas áreas productivas. Y no solamente un uso sostenible en función de la reserva, sino también en función de ser un referente a nivel regional. Es decir, si en la reserva empezamos a adoptar cierta cultura y ciertas prácticas de manejo del agua, de manejo del suelo, de manejo de la ganadería, de manejo de cultivos, podemos ser, de alguna manera, una vitrina, y un aula donde se pueda hacer esa pedagogía para beneficio de la región, pues porque conservar las doscientas áreas, las doscientas o 170 hectáreas o 150 hectáreas de bosque eso es insuficiente, eso es una miniatura. Lo que necesitamos es convocar a otros propietarios de la región para que adopten prácticas similares a las nuestras, para que en conjunto el efecto sea significativo. Pues doscientas hectáreas sí muy bonito y tal, pero pues digamos a escala del paisaje eso es un punto. (Entrevista a Carlos Castillo, jefe de la RBE, 18 de enero de 2013. Cursivas del autor) 
Tal como lo expone el jefe de la RBE, lo que se pretende es fomentar cierto tipo de usos de los recursos del entorno en la región. La adopción de nuevas formas de usufructo de los recursos naturales hace parte, según su interpretación, de un cambio cultural. Allí reposa un elemento clave de su forma de entender las maneras de relación de los seres humanos y su entorno, a saber, la mediación cultural, entendida como cierto de tipo de prácticas. En buena medida, se busca generar un cambio en las actividades de producción agropecuaria de la región en pro de la sostenibilidad. Estos cambios son fomentados por la educación de la población local frente al uso de los recursos naturales. En consecuencia, la intervención se hace por medio de la enseñanza, en este caso indirecta a través del ejemplo ("vitrina” y "aula”).

La existencia de "áreas productivas", en opinión del jefe de la RBE, es una forma tanto de educación para la población local como de financiación de la reserva. Esto plantea una visión de las áreas protegidas no solo en cuanto a su impacto directo en la protección de las zonas delimitadas, sino en su convergencia con la producción en pro de beneficios económicos y una intervención indirecta sobre las formas de vida locales. Aquí entran en juego las disputas sobre las formas de determinar lo que se considera propio de un área protegida, así como lo adecuadas o inadecuadas de ciertas prácticas de usos de los recursos naturales. Las áreas protegidas intervienen el aprovechamiento del entorno, a la vez que fomentan indirecta o directamente ciertas formas de entender la naturaleza. 
La restauración de todos los potreros (que según el jefe de la RBE no sucederá) tendría repercusiones para las actividades ganaderas locales e, incluso, sobre la financiación de la RBE. Algunas de las apreciaciones de los vecinos al respecto citadas anteriormente parten del desconocimiento del plan de manejo de la RBE, pues no ha habido un diálogo formal y de concertación entre la FNC y la población local. Con todo, no deja de ser una fuente de preocupación teniendo en cuenta lo discutido en el capítulo in frente a las formas de trabajo que ofrece la FNC de manera directa a los pobladores locales.

Por el momento, ha sido fundamental que la FNC esté brindando la posibilidad a los habitantes de ejercer labores agropecuarias que les representan una fuente constante de ingresos que les permite vivir. Teniendo en cuenta este aspecto de la ganadería como opción laboral clave a partir de las concesiones en la RBE, se le preguntó al jefe de la reserva sobre la disminución de los potreros, las afectaciones que esto podría traer para la población y qué alternativas se podrían plantear para las familias:

-Felipe Rojas: ¿Y digamos ese número [de familias beneficiadas por la venta de pastos] puede fluctuar por los procesos de restauración o...?

-Carlos Castillo: Sí es posible que fluctúe, y digamos en eso también se ha hecho claridad ¿no? O sea que hay áreas que probablemente se van a disminuir por el proceso de restauración, pero hay otras que se van a conservar porque francamente su vocación es esa [ganadera] y si se les da un 
manejo adecuado pueden precisamente sostenerse, que a lo largo del tiempo puedan seguir siendo productivas. -FR: ¿Y se podrían plantear alternativas para esas familias de pronto que ya no pudieran seguir en el proceso de manejo productivo?

-CC: Yo sí creo que es importante, también hay que trabajar. O sea digamos lo que hay actualmente es un modelo de ganadería que tiene una tendencia más es hacia lo extensivo. De pronto se pueden reducir las áreas y dar manejos intensivos, pero sostenibles. Y se pueden también desarrollar otras actividades que no se están desarrollando, como por ejemplo producción o propagación de especies ornamentales, de orquídeas, de bromelias, agricultura orgánica, en fin. Cosas que no se están haciendo que se pueden hacer y que pueden generar otras alternativas de ingreso para los pobladores y si en algún momento hay una descompensación, digamos porque se reduce la oferta de áreas en concesión [venta de pastos], pues pueden por lo menos tener de dónde agarrarse. Va a depender de ellos el que lo hagan ¿ no?, el que lo asimilen [...]. (Entrevista a Carlos Castillo, jefe de la RBE, 18 de enero de 2013)

A partir de esta cita, se puede deducir que, si bien todos los potreros no serán restaurados, la economía local puede verse afectada a partir de su reducción. Ante esta situación, habrá que ver cuáles medidas adoptará la FNC o cuál será su interés de contribuir al mejoramiento y la mitigación de estos problemas y cómo la población responderá ante estos cambios en sus prácticas productivas. 
Los cambios en el uso de los recursos ambientales podrán llegar a ser más profundos, pues, como lo expresa el jefe de la RBE, nuevas actividades económicas podrán darse en la vereda, como por ejemplo siembra de plantas ornamentales o agricultura orgánica. En este sentido, este estudio tiene como clave la localización de estas tensiones a partir de un conocimiento etnográfico. La perspectiva antropológica, entonces, es fundamental para dar cuenta de qué manera se dan en escenarios locales las luchas ambientales desde diversos matices. Una de las principales aristas que enfatiza el estudio antropológico de este tipo de tensiones es por cuenta de los significados:

-Felipe Rojas: ¿Pero entonces qué va a ser de las vaquitas cuando ya no haya potreros?

-Vecina: Por eso. Qué irán a hacer toda esa gente que tiene sus ganadito, quéirán hacer. Ahí otra miseria, otro terrible. Porque ya entonces ya ni un animalito ni nada. Eso es lo que se siente. Porque apenas ver ahí monte. Y ahí entonces principian a llegar las fieras, principia a llegar el oso, el león, el tigre. Y lo que dice en la sagrada biblia. No ve que dice que los últimos tiempos vendrán los animales, las fieras a poseer la casa de los justos. Y los justos irán a poseer la ca[sa], la madriguera de las fieras. En la sagrada biblia está. (Entrevista a pobladora local, 2 de septiembre de 2012)

Esta persona no solo habla de las carencias económicas que podría generar la siembra de árboles en todos los potreros, que por lo demás lo presenta de una manera sumamente 
desalentadora, sino que existen reparos simbólicos. Es interesante ver cómo esta vecina considera que al llenarse todo de "monte", los animales salvajes y peligrosos poblarían el lugar y serían una fuente de peligro para los vecinos. Este pensamiento está mediado por creencias apocalípticas del final de los tiempos. La forma de entender la naturaleza con sus propiedades de salvaje o peligrosa hace parte de una simbolización del entorno y sus usos.

Lo interesante de la anterior cita es que sugiere que los pobladores no solo tienen reparos en tanto sujetos económicos, sino que su capacidad de representar la naturaleza les permite interpelar las actividades desarrolladlas por la FNC, en particular los programas de restauración ecológica. Autores como González y Múnera (1998) plantean la necesidad de conocer las variables culturales que afectan e influyen en las formas de producción de los habitantes locales para el caso amazónico de la región de El Pato. Por su parte, Toledo y Barrera (2008) establecen una correlación entre cultura y prácticas productivas. Me parece interesante esta propuesta, pues da un papel relevante a aspectos culturales e históricos en el establecimiento de estrategias de diagnóstico de usos de los recursos del entorno y resolución de conflictos ambientales en comunidades campesinas. Esta propuesta analítica sugiere la relevancia del interés de la antropología por el estudio de las formas simbólicas de apropiación del ambiente en la determinación de planes de manejo ambiental. A continuación se dan a conocer algunas opiniones que dan cuenta de la apropiación simbólica de la naturaleza que repara la siembra de árboles en la RBE: 
Pasa como en el Caquetá. Sí. Eso es lo que se siente porque, porque qué tal que, que como en el Caquetá que allá se apoderó la guerrilla de todo esas montañas. Como la guerrilla tira es al monte, entonces claro que por aquí se va, se irá, Dios nos favorezca que se vaya a convertir en casa de la guerrilla. Porque esa gente tira es al monte. (Entrevista a pobladora local, 2 de septiembre de 2012).

[...].

Pero lo malo es que ahorita todos los potreros los están sembrando en solo árboles y de pronto pues más inseguridad porque pues en todos esos árboles pueden haber robos o bueno, en fin, cosas. (Entrevista a pobladora local, 6 de diciembre de 2012)

Otro tipo de desacuerdos tienen que ver con elementos como el clima, debido a que algunos consideran que al sembrar más árboles, la temperatura del lugar se enfriaría aún más:

Uy, pero en esa parte sí me parece tenaz que siembren y siembren árboles porque es que el frío acá es tenaz. Y se imagina si siguen sembrando árboles, pues esto ya es un páramo. (Entrevista a vecina del sector 27 de agosto de 2012)

Estas opiniones sirven para superar el reduccionismo de pensar que los campesinos son solamente sujetos económicos, carentes de otras motivaciones para apropiarse de los espacios naturales en los que intervienen e interactúan, como por ejemplo las de tipo simbólico. Esto abre posibi- 
lidades para tener en cuenta cuáles son sus opiniones sobre el usufructo de los recursos naturales y las afectaciones que ello puede traer no solo en su economía, sino en su seguridad y salud.

Estas formas de pensar los árboles y su siembra en los potreros dan cuenta de la manera en la que se entiende el territorio y el entorno. La naturaleza es vista como un sitio salvaje, indómito y peligroso que puede traer peligros aunados al conflicto armado que vive el país o la delincuencia. Es interesante pensar cómo se diluyen los peligros humanos y los no humanos. La espesura del bosque tiene relación con peligros provenientes de sujetos como los ladrones o guerrilleros, lo que ayudaría a pensar en formas de representar a la naturaleza y a algunos humanos como intrínsecamente relacionados. Tal percepción permite dar cuenta de formas de trascender la división cultura-naturaleza. Ambas entidades se mezclan a la hora de pensar en la guerrilla o los ladrones que son como "especies salvajes" que habitan los bosques y selvas, al acecho para causar daños. El debate que plantea este tipo de opiniones se da frente a las formas en las que entendemos las necesidades de las poblaciones aledañas a las áreas de conservación. No se trata solamente de brindarles posibilidades económicas para su subsistencia, sino de articular la conservación con, y respetar, sus formas de entender el aprovechamiento de los recursos naturales y la relación con sus representaciones de la naturaleza.

Casos como el que presenta Durán (2009) para el Parque Nacional Natural Corales del Rosario y San Bernardo muestran cómo se desconocen las formas de usos de los recursos 
naturales y los conocimientos locales desde unas lógicas coloniales que ignoran y acusan a la población de ser la causante del deterioro ambiental. Esta tensión entre formas de vida, conocimientos locales y restricciones sobre el uso de recursos ambientales tiene un carácter global. Ha habido diversos casos en otras regiones y países en los que se han planteado una serie de alternativas que me parece pertinente traer a colación. Algunos versan sobre el desarrollo del ecoturismo teniendo en cuenta unas políticas de manejo que permitan la sostenibilidad de la población local y el ambiente a partir de esta actividad (Durán, 2009).

En la reserva faunística del Chimborazo, en Ecuador, se establecieron diálogos entre los conocimientos de la población local y los modelos ecoturísticos, se hicieron inventarios biológicos y se determinaron usos adecuados y no adecuados de los recursos naturales a partir de ello (Burbano, 2005). En otros casos, se han planteado propuestas interesantes de zonificación, un proceso que consiste en delimitar zonas aptas para el ejercicio de ciertas labores de conservación o producción como en el parque Los Alerces, en Argentina (Myers y Uribelarrea, 1992), o la Reserva Biosfera Maya, en Guatemala, en donde se propusieron áreas de usos múltiples y zonas de amortiguamiento para el aprovechamiento forestal de la población (Monterroso, 2006). Estos casos muestran que estas tensiones por el uso de los recursos naturales trascienden a Guasca y tienen un carácter global. Además, ponen en común propuestas que sirven para pensar planes de acción como la zonificación y el diálogo y la concertación con la población local, como herramientas 
clave para el manejo de áreas protegidas que se analizarán a continuación.

\section{Propuestas de los pobladores locales para el uso de la tierra, zonificación y articulación de usos "tradicionales" y usos de la conservación}

La valoración de los diversos tipos de conocimientos y propuestas de uso de los recursos naturales de los pobladores locales es una de las premisas del manejo ambiental comunitario y un punto de discusión dentro de la ecología política, que parte de los aportes de la antropología en el estudio de los saberes locales. Un artículo novedoso en su argumento sobre las formas de conocimiento ecológico tradicional (conocido como TEK, por su sigla en inglés), por su diferenciación de acuerdo al género y la edad, es el de Burbano (2005). Esta autora propone un diálogo de saberes locales y saberes de la conservación que permita conocer cuáles son las diferentes posiciones e intereses sobre los recursos naturales de diversos actores en el marco de la resolución de los conflictos ambientales. En particular, la autora propone un enfoque etario y de género, ya que considera que a partir de estos roles sociales surgen intereses y conocimientos diferenciados sobre los recursos naturales, muy relevantes a la hora de plantear el manejo de áreas protegidas.

Por su parte, autores como Wittmayer y Büscher (2010) y Tsing et al. (2005) discuten el modelo de manejo de recursos naturales basado en comunidades. Definen que uno de los pilares de este modelo es el reconocimiento de las tradiciones y los conocimientos locales frente a los recursos naturales y 
las complejidades de las prácticas y los procesos ecológicos, por lo menos en teoría. En este orden de ideas, dentro de la resolución de conflictos ambientales por el aprovechamiento de los recursos naturales, es pertinente fomentar un diálogo entre conocimientos locales y conocimientos de la conservación. En Pueblo Viejo ha faltado hasta el momento una discusión entre los administradores de la RBE y la población local en donde estos puntos se hagan visibles, pues aún están en formulación:

-Felipe Rojas: ¿Y de pronto en esos talleres que piensa implementar usted para este año, eh cabría la posibilidad de establecer por ejemplo cuáles son las propuestas que tendría la población frente al manejo de ciertos temas en la reserva, lo digo en el sentido de algunas propuestas, de algunos proyectos que ellos quieran manejar?

-Carlos Castillo: Claro, claro, claro. Digamos que son procesos abiertos, digamos que nosotros tenemos en mente algunas cosas y si ellos tienen otras ideas que pueden ser buenas, viables, son bienvenidas, digamos es un sistema abierto, no es un sistema impositivo. ¿Si?, ¿ es hacia eso a donde iba tu pregunta?

-FR: Ajá. Digamos que hubiera como reuniones periódicas con la población, de pronto cada tanto tiempo donde se pudiera dialogar con ellos, con lo que usted decía de los que tienen las concesiones en la reserva con su ganado, que plantearan sus inquietudes frente a lo que están manejando y ustedes también de decirles “este manejo sí o no o cómo 
nos articulamos entre unos usos sostenibles, pero que pues garanticen la subsistencia local”.

-CC: Sí, esos espacios periódicos se van a dar, esos encuentros periódicos están dentro del plan de trabajo, por lo menos para este año y seguramente que esto habrá que extenderlo en el tiempo porque seguramente que van a ser procesos exitosos. La interacción con la comunidad es una cosa que va prevalecer en el tiempo. (Entrevista a Carlos Catillo, jefe de la RBE, 18 de enero de 2013)

Durante el trabajo de campo y las conversaciones con las personas, se pudo constatar que estos procesos de diálogo, en el sentido de participación e interacción para la construcción de propuestas entre la población y la FNC, no han tenido lugar hasta el momento. Con todo, el jefe de la reserva se muestra interesado en implementar una serie de talleres de educación ambiental, ${ }^{16}$ e incluso reuniones para la construcción de propuestas sobre el manejo de la RBE.

En lo que respecta al usufructo de los recursos del ambiente, en particular la tierra, la población local expone propuestas sobre su manejo al interior de la RBE que tienen que ver con sus conocimientos del entorno. En un modelo CBNRM la consulta con la comunidad, el reconocimiento del sufrimiento humano por cuenta de la conservación y del valor de las tradiciones comunales y sus formas de manejo

16 En el capítulo in se describió uno de los procesos que se dio -tal vez el único hasta el momento- de capacitación de la población local en temas ambientales en el proyecto de ecoguías. 
de los recursos naturales y el aumento (y negociación) de los derechos de las poblaciones rurales en términos de acceso e intercambio de los recursos son fundamentales, por lo menos en teoría (Wittmayer y Büscher, 2010).

En consonancia con lo anterior, algunos autores definen que el modelo CBNRM implica tres elementos: 1) permitir a aquellas poblaciones que habitan cerca de áreas protegidas la participación en las políticas del uso de la tierra y su manejo, 2) brindarles derechos de propiedad sobre los recursos naturales, y 3 ) otorgarles beneficios económicos a partir de la conservación ambiental (Hackle, 1999, p. 727, citado en Büscher y Dietz, 2005, p. 3).

El debate sobre el CBNRM es complejo (como se presentó en el capítulo I) e implica tener en cuenta que la base de este sistema es la pretensión, no necesariamente acertada, de que las comunidades están en la capacidad y tienen el interés de manejar sus tierras y recursos ambientales enfocados hacia la conservación ambiental y pretenden establecer reglas al respecto a través de un uso sustentable basado en la propiedad común (Roe et al., 2009; Tsing et al., 2005).

En ocasiones, esto no resulta estar acorde con las comunidades locales porque no necesariamente hacen usos "sustentables" de los recursos naturales, lo cual vulnera la sostenibilidad ambiental, pero también la subsistencia de las personas. Adicionalmente, se generan imposiciones de lo que es "sustentable" con base en intereses económicos, políticos y ambientales. No en vano este modelo es visto como una forma colonial de control, coerción y despojo sobre 
las poblaciones locales y sus recursos o de imposición de ciertos modelos y políticas de desarrollo (Tsing et al., 2005).

La declaración de lo que es o no sustentable no puede pensarse como una práctica neutra, sino enmarcada en relaciones de poder en donde se privilegian unos conocimientos y prácticas en detrimento de otros. Muchas de estas pretensiones están basadas en imaginarios occidentales sobre la naturaleza ecológica de las comunidades locales, en particular las indígenas. ${ }^{17}$ Las identidades encasilladas de los "nativos ecológicos" limitan los proyectos de vida de estas poblaciones que no necesariamente están alineados con la conservación o con imaginarios erróneos sobre su dependencia de los recursos (Li, 2002).

En la práctica del manejo de los recursos naturales, estas comunidades están subordinadas al estado, pues no son totalmente autónomas (a diferencia de lo que propone el modelo CBNRM a nivel conceptual), en tanto su derecho de manejo está sustentado en el poder que les trasfiere el estado (Roe et al., 2009).

Las comunidades no tienen el derecho de manejo por ser pobladores históricos del lugar y anteriores a la constitución de áreas protegidas, sino por cuenta del poder estatal o el que hace sus veces. El estado toma posesión de los recursos ambientales que pertenecen a las comunidades para luego otorgárselos por medio de concesiones de manejo, lo cual

17 Un texto interesante sobre la construcción de los indígenas como ecológicos es el de Astrid Ulloa (2004), titulado: La construcción del nativo ecológico: complejidades, paradojas y dilemas de la relación entre los movimientos indígenas y el ambientalismo en Colombia. 
es sumamente contradictorio. Esta situación imposibilita el real empoderamiento territorial de las poblaciones a través del modelo CBNRM. Además, este sistema crea comunidades imaginarias igualitarias desconociendo la heterogeneidad y diferencias de clase, género, etnicidad, edad, entre otras (Li, 2002; Wittmayer y Büscher, 2010). En buena medida, las críticas a este modelo parten del desfase que existe entre las teorías que lo sustentan y la realidad de las poblaciones cercanas a áreas protegidas. Tsing et al. (2005) critican este modelo por su aplicación descontextualizada, generalizante y deshistorizada.

$\mathrm{Li}$ (2002) sugiere que para que este sistema funcione, las reglas de conservación, manejo y asignación de los recursos naturales deben ser propuestas por la comunidad en cuestión, lo que supone una tensión con el modelo CBNRM, que propone que la conservación debe ser monitoreada por el estado. En este orden de ideas, es interesante analizar cuáles son las propuestas que presenta la población en cuanto al uso de la tierra en la RBE porque estas pueden contribuir a generar formas de participación efectivas en el manejo de la reserva. Las propuestas locales son fundamentales en la búsqueda de soluciones a los conflictos ambientales.

Más allá del modelo CBNRM que se viene discutiendo, es clave que en la RBE las poblaciones sean partícipes del manejo de esta no por imposición de actores externos, sino desde sus representaciones, necesidades e intereses de lo que debe ser la reserva. Partiendo de considerar la heterogeneidad de la población, sus saberes sobre el funcionamiento de la naturaleza, sus motivaciones e intereses frente a los beneficios y 
recursos naturales de la $\mathrm{RBE}$, se puede llegar a construir un manejo más justo y democrático. Muestra de estos intereses, perspectivas y conocimientos locales son las diversas citas presentadas a lo largo de este texto. Aquí otra de ellas:

Porque es que acá en la reserva no tienen en cuenta una cosa, que los árboles se siembran es en las cabeceras, dónde está la tierra árida, digamos que para que coja humedad y lo están sembrando en cualquier lado, y digamos en los potreros aprovechables. Porque los árboles se deben sembrar es en las cabeceras de los potreros, donde hay esas lomas que no sale pasto, se siembra árboles y se abona la tierra se arregla y llama humedad. (Entrevista a poblador local dedicado a la ganadería, 3 de septiembre de 2012, cursivas del autor)

En la opinión de este poblador local saltan a la vista dos elementos. De un lado, denota una tensión por los conocimientos frente al uso que se le debe dar a la tierra. Su reparo versa sobre la siembra de árboles en ciertos lugares en donde no es debido hacerlo de acuerdo con su concepción, pues esto daña los potreros aprovechables para ganadería y agricultura. Este poblador expresa un conocimiento particular de la necesidad y las maneras de sembrar árboles en sitios determinados, debido a su vocación y características, lo que sugiere un segundo elemento: la zonificación. Este concepto, si bien no es acuñado directamente por el vecino, responde a la necesidad de sembrar árboles en los sitios menos aptos para pastoreo o sitios secos para su recuperación. La zonificación hace 
referencia a la delimitación y división de un área geográfica y las actividades en ella permitidas de acuerdo con la vocación de los suelos y los ecosistemas.

Acorde con ciertos modelos analíticos, un conflicto por el uso de la tierra se presenta en algunos casos cuando un aprovechamiento que no es apto para su vocación es practicado (González y Múnera, 1998), que es precisamente lo que sugiere, entre otras, la última cita textual presentada. En el caso de Guasca, el conflicto tiene esta característica, aunque en esta investigación se discrepa con el modelo analítico de los autores mencionados que establece solo criterios técnicos para determinar la vocación, pues, en mi opinión, los conocimientos locales no tecnificados sirven para determinar vocaciones y diagnosticar conflictos por el uso de los recursos ambientales.

La lógica del saber-poder presente en el argumento de González y Múnera otorga mayor legitimidad a los conocimientos técnicos ignorando otro tipo de saberes muy útiles y válidos para la determinación de la vocación de los suelos, como antesala a la zonificación. Los testimonios que se han citado dan cuenta de la existencia de conocimientos particulares que poseen los pobladores locales frente a las formas adecuadas de sembrar árboles y utilizar la tierra en la RBE, las cuales entran en tensión con los propuestos por la FNC.

González y Múnera (1998) asumen que los patrones culturales deben ser tenidos en cuenta para el diagnóstico de los modos de producción locales, en aras de su posterior modificación para mejorar las condiciones de conservación. Pero en el caso de la RBE, y de acuerdo con el fragmento de 
entrevista citado y la experiencia en campo, se considera que es necesario tener presente de qué manera estas poblaciones poseen unos conocimientos y unas experiencias particulares del medio que es necesario tener en cuenta para determinar la vocación del suelo, además de los criterios técnicos.

González y Múnera (1998) desconocen cuál ha sido la relación empírica de las poblaciones locales con el ambiente y su importancia para conocer el entorno y su vocación. En consecuencia, no se debe tener en cuenta los conocimientos locales solamente para su intervención, sino rescatar de ellos su aporte para el manejo de recursos naturales y establecimiento de zonas aptas y no aptas para el ejercicio de ciertas actividades en áreas protegidas. Esta idea de conocer la cultura para modificar prácticas productivas está también presente en las consideraciones del jefe de la RBE:

Claro, en la medida en que nosotros tenemos unas áreas productivas que estamos dando en concesión, pues digamos solicitamos a esos concesionarios que adopten, pues no de una manera impositiva, sino de una manera pues racional persuasiva, y ahí es donde entra el tema del cambio cultural. Cultura son las costumbres, costumbre de amarrar la vaca o soltarla o dejarla que haga lo que le dé la gana versus ¿no? manejar la cosa de otra manera. (Entrevista a Carlos Catillo, jefe de la RBE, 18 de enero de 2013

Esta visión de la cultura del jefe de la RBE contrasta profundamente con otro tipo de apreciaciones que abordan el asunto con mayor profundidad al dotar de sentido a las 
costumbres: "Entiendo por lógica cultural la estructura de sentido que subyace a las prácticas y estrategias campesinas, mediante las cuales hacen uso de los recursos y manejan las restricciones ecológicas y las dificultades económicas" (Cano, 2005 , p. 46, cursivas del autor). Lo interesante de este concepto es que adjudica a las costumbres y creencias culturales un papel importante en la configuración de sentido del mundo campesino, en tanto influyen en las formas productivas, de pensar el entorno y de aprovechamiento de sus recursos, lo cual contrarresta los análisis economicistas sobre las motivaciones campesinas y sus formas de apropiación del ambiente, como se discutió en el capítulo I.

El concepto de cultura es difuso y difícil de definir y encasillar, ${ }^{18}$ pero lo cierto es que no se trata solo de las costumbres, sino también de las creencias, el acervo cultural de conocimientos, las formas de representación, la experiencia empírica, las formas productivas, los mecanismos de socialización, entre otros aspectos. No hace parte únicamente del dominio de las prácticas y costumbres, sino de las estructuras de sentido, representaciones, trayectorias históricas, entre otros. La complejidad de este asunto es abordada por Toledo y Barrera (2008) al proponer intrincadas relaciones entre la cosmovisión y la cosmología de ciertos grupos humanos y sus formas de apropiación de los recursos naturales. Un cambio cultural va más allá de las prácticas, pues tiene relación con

18 Para una discusión de las diversas definiciones de cultura, su genealogía y trayectoria como concepto en la antropología, véanse Williams (2003) y Cuche (2007). 
unas formas de aprehensión y entendimiento del mundo decantadas por generaciones en la memoria individual y colectiva (Toledo y Barrera, 2008).

La indagación en terreno por la historia del poblamiento de Pueblo Viejo arrojó resultados interesantes frente a los conocimientos que pueden tener estos habitantes frente al medio circundante. Gran parte de las familias de este sector aseguran que sus padres y abuelos, y en algunos casos bisabuelos, son originarios de Pueblo Viejo. Algunas de las propiedades de estos habitantes son herencias familiares de sus padres y abuelos. Además, parte de las tierras posesión de la familia Hoeck pertenecieron a algunos de los ancestros de la población local, quienes la vendieron a esta familia. Según algunas de las escrituras del archivo de la Notaría del Circuito de Guatavita, la familia Hoeck hizo numerosas transacciones de predios con algunos de los familiares y ancestros de las actuales familias del lugar (Notaría del Circuito de Guatavita, 1943; 1945; 1946; 1947; 1948; 1949; 1958; 1966; 1970). Esta permanencia en el sector por varias generaciones sugiere que existe un conocimiento empírico y una prolongada interacción con el ambiente por parte de estos pobladores que pueden ser indispensables para la elaboración de los planes de manejo de la reserva, incluida la zonificación. ${ }^{19}$ Parte de este conocimiento se expresa en otras apreciaciones:

19 Toledo y Barrera (2008) abogan por la importancia del conocimiento empírico y mnemotécnico tradicional en la elaboración de planes de uso de los recursos en diálogo con el conocimiento técnico. 
Por decir algo, si yo tengo un lote, siembro árboles por la orilla de las quebradas, siembro árboles por la cabecera del potrero, pero nunca en la mitad, nunca eso. Porque hay potreros que no son aprovechables, lomas que por ejemplo allá uno dice allá no sale tanto pasto y qué rico que arboricen [...]. (Entrevista a poblador local dedicado a la ganadería, 3 de septiembre de 2012)

Una persona, a quien se le preguntó sobre la siembra de árboles, respondió lo siguiente:

Sí, así alrededor y qué dejarán, ¿ sabe qué decía yo?, así [que sembraran] alrededor y que dejaran los potreros libres, y podían vender, les salían más mejor vender los pastos. Sí, porque servían más, recibían la plata de los pastos que vendieran y así pa' los animalitos tenían ahí sus pastadas. (Entrevista a habitante local, 2 de septiembre de 2012)

Esta última persona comentó que le parecía que se debían sembrar los árboles en la RBE alrededor de los potreros y no en su interior, pues esto dañaba las fincas. En su manera de entender y conocer cómo se deben sembrar árboles en las fincas, salta a la vista una forma particular de usar la tierra que privilegia el cuidado de los potreros. Los conocimientos locales en Guasca se expresan en el saber frente a la vocación del suelo, la siembra de ciertas especies de árboles como alisos o eucaliptos y pinos como causa de la proliferación de fuentes hídricas o la erosión o daño de ciertos terrenos y la ausencia de agua, respectivamente. Otro tipo de conocimiento se expresa 
en las formas de contrarrestar temporadas secas acompañadas de heladas. En alguna ocasión, un vecino de Guasca explicaba que regando la huerta por la tarde con abundante agua se evitaba el daño causado por la helada durante la madrugada. Maneras de interpretar y hacer frente al clima, los conocimientos frente a la utilidad de ciertas plantas medicinales nativas tanto para humanos como para el ganado, así como comentaba una vecina de Guasca en alguna ocasión, son, entre otras, formas de conocimiento que tienen estas personas sobre el entorno.

Este conocimiento sobre el cuidado y uso de la tierra hace parte de unos saberes que entran en tensión con las formas de usufructo de los recursos ambientales en la RBE. Este tipo de opiniones arrojan luces sobre las propuestas de uso de la tierra que tiene la población para la RBE; usos y conocimientos que pueden ser tenidos en cuenta a la hora de formular planes de manejo y que empiezan a sugerir una zonificación de acuerdo con la vocación de los suelos que priorice cierto tipo de aprovechamientos. Para promover procesos de restauración del entorno, la estructura y función de los ecosistemas modificados, es necesario tener en cuenta los saberes de las poblaciones locales que conocen estos recursos y sus cambios a lo largo del tiempo (Cano, 2005). Así lo expresa una persona miembro de una familia dedicada a la ganadería:

Para ciertos terrenos [la siembra de árboles] fue la mejor opción. Porque, por decir algo, donde exploraban la piedra de cal ahí en eso fue una buena opción, exactamente. Porque es que digamos que le estamos envidiando a la reserva, no. 
Porque digamos la reserva tiene su derecho, como la tenemos todos, pero es que pa' ciertos terrenos tiene beneficio. Donde sacaron, donde estaban sacando esa piedra de cal, que se estaba erosionando, toda esa tierra se estaba abriendo, sembraron árboles, pues lógico que arreglaron y se va arreglar ahí y se va a volver esto a reforestar. Estamos hablando de los montes, de las lomas, de las cabeceras, pero en donde la están embarrando es en los potreros, digamos en los potreros aprovechables. (Entrevista a poblador local, 3 de septiembre de 2012)

Una persona, cuya familia se dedica a actividades pecuarias lo expresó así:

[...] como por ejemplo en partes donde son buenos potreros y eso no deberían de meter árboles [...]. Sí, eso por ejemplo deberían de seleccionar, cada, por ejemplo para las orillas, o nacederos del agua, sembrar lo que es por ejemplo aliso y eso que es lo que llama el agua, pero hay buenos potreros que ahí deberían dejar para pastoreo, pero con el tiempo yo creo que eso no, eso vienen acabando. (Entrevista a habitante de Pueblo Viejo, 27 de agosto de 2012, cursivas del autor)

Es interesante cómo las personas sugieren que el uso para siembra de árboles debe hacerse en zonas menos aptas para el pastoreo y con cierto tipo de especies, en especial en los bordes de los potreros, pues esta es una manera de articular los usos que propone la FNC en cuanto a ganadería y restauración ecológica. Sugieren, además, lo poco apto que resulta el 
desarrollo de la actividad minera y la importancia de sembrar para recuperar el daño de la explotación. Muchos proponen que sí es benéfico que se siembre la especie aliso (Alnus acuminata) en ciertas zonas, pues, según su conocimiento ecológico "tradicional”, es una especie que fortalece la humedad y proliferación de fuentes hídricas.

Durante la entrevista, una persona expresaba estar de acuerdo con la forma en que la FNC estaba usando las tierras en actividades mixtas: ganadería y restauración ecológica. Para ella, la FNC estaba haciendo un adecuado uso de la tierra en tanto permitía la ganadería en zonas aptas para su ejercicio, mientras que restauraba (reforestaba en sus términos) las partes que producían menos pasto. Detrás de estas opiniones existe una lógica de zonificar de acuerdo con la vocación y productividad de los suelos de la RBE. Este tema ha sido objeto de trabajo y discusión dentro de los planes de manejo en diferentes áreas protegidas alrededor del mundo. En Colombia, existen casos como el de La Macarena en donde, mediante el Decreto 1989 del 1 de septiembre de 1989, se crea el Área Especial de Manejo de La Macarena, con el fin de buscar el bienestar social y ambiental, además del establecimiento de una zonificación interna de acuerdo con el potencial y deterioro de los suelos en el Parque Nacional Natural ubicado en esta región (Castaño, 1992). En el Parque Nacional Sierra Nevada en Venezuela se planteó una zonificación para promover o excluir ciertos usos de acuerdo con las características de cada área, en el marco de un diálogo con la población, que reconoció los valores y las prácticas tradicionales de las culturas campesinas (Reyes y López, 1992). 
Estos casos muestran algunas de las tendencias de manejo de áreas protegidas de la mano de las poblaciones. Son un marco de referencia de posibles planes de acción que aún no han sido propuestos en la RBE y que enfatizan en la zonificación concertada como salida viable a conflictos por el uso de los recursos naturales. Asimismo, estos casos muestran cómo las tensiones por el uso de la tierra en la RBE no se encuentran aisladas, sino que hacen parte de procesos globales de cuidado y manejo ambiental que implican tensiones y negociación entre las partes involucradas.

La zonificación es solo una de las propuestas para el manejo de las áreas protegidas. Existen otro tipo de iniciativas que, de la mano de la zonificación, pueden fomentar la disminución de los conflictos por el aprovechamiento de los recursos naturales entre administradores de áreas protegidas y la población local, así como promover tanto la conservación como la subsistencia. El diálogo y la concertación son algunas de las actividades sugeridas en diversos casos que permiten que la población se haga partícipe en los planes de manejo de las áreas protegidas y protección ambiental en aras de resolver conflictos por el uso de recursos, el deterioro ambiental y el desarrollo local (Del Cairo, 2010; Osidala, et al., 1992; Durán, 2009; Londoño, 2008). Esta propuesta se debe hacer de la mano de los conocimientos locales sobre la aptitud y vocación de los suelos. Con todo, las discrepancias por el uso de los recursos ambientales son de parte y parte:

-Felipe Rojas: ¿O sea que ustedes creen que algunos de los usos que están dando, que están ejerciendo los pobladores 
locales no son sostenibles, qué usos serían esos o en qué hay que mejorar en ese sentido?

-Carlos Castillo: Sí, claro que hay mucho en el manejo del recurso hídrico, por ejemplo, digamos no hay una cultura de ahorro porque, entre otras cosas, es una zona rica en fuentes hídricas, pero si vemos, si hubieras ido en estos días en que hubo sequía ya la gente estaba [gesto de preocupación], pero es porque no ahorran. Desperdician agua todo el año. "Sí que qué invierno y qué cosa y qué llovedera y", pero si no se ahorra el recurso, entonces hay esos desequilibrios.

-FR: ¿Y en las actividades pecuarias, habría...?

-CC: También. Hay muchos temas en la actividad pecuaria que pueden mejorarse en una lógica de sostenibilidad. Como en las praderas, el manejo y control de plagas, digamos que las mismas coberturas de pastos y todo eso hay muchísimos aspectos en que pueden mejorar su productividad y la sostenibilidad, esos indicadores en ambos sentidos. (Entrevista a Carlos Castillo, jefe de la RBE, 18 de enero de 2013)

En Pueblo Viejo existen desacuerdos por el uso de la tierra entre la población local y la FNC. Si bien hay puntos en los que ambas partes concuerdan, en especial en cuanto a la importancia de sembrar árboles para recuperar el daño ambiental causado por la mina o incrementar las fuentes hídricas, los habitantes consideran que la FNC está mal utilizando algunas zonas al sembrar árboles en los potreros que pueden llegar a tener una vocación productiva. 
A futuro, consideran muchos, los potreros al interior de la RBE van a escasear en su totalidad, lo que los obligará a vender su ganado y buscar otro tipo de actividad económica. Sin embargo, esta opinión parte del desconocimiento y la falta de diálogo entre estos dos actores, pues, así como lo expresa el jefe de la reserva, no todos los potreros van a ser restaurados. En suma, los conflictos por los usos de la tierra se relacionan con las consideraciones que tienen los diversos actores sobre la capacidad de los suelos, los conocimientos ambientales, las relaciones entre el saber y el poder, la representación de la naturaleza y las actividades económicas.

En este capítulo se sugiere la necesidad de contextualizar los conflictos de los recursos naturales en el marco de las relaciones desiguales de poder que, en este caso, parten del régimen de propiedad privada que pesa sobre la reserva y la posición que ocupó por muchos años la familia Hoeck como empleador y arrendador de la población local. Estas dos características hacen que la FNC sea la que tenga la capacidad de proponer lo usos de la tierra al interior de la RBE. Por otro lado, estos conflictos y tensiones deben entenderse como procesos en los cuales los sujetos no asumen de manera pasiva los usos, sino que tienen la capacidad de oponerse o acogerse a estos. Los sujetos toman posiciones frente a los aprovechamientos de la tierra de acuerdo con el lugar que ocupan en la jerarquía social, sus actividades económicas, sus aspiraciones de vida e incluso sus formas de representar la naturaleza y sus saberes. 
Esto implica no considerar a las comunidades como homogéneas, sino entender sus diversas formas de usar y conocer los recursos ambientales de acuerdo con sus roles sociales (Burbano, 2005). El diálogo y la concertación son algunas de las herramientas útiles para solucionar estos conflictos, toda vez que las partes se conozcan y entienden sus motivaciones para tomar ciertas posiciones con respecto al uso de los recursos naturales.

La restricción y el cambio sobre los aprovechamientos de los recursos naturales que trae consigo un área protegida son motivos constantes de disputa y negociación entre las distintas partes involucradas. La tensión es mayor en tanto los usos introducidos por la conservación en la RBE son ajenos a muchas de las experiencias y conocimientos locales.

Para algunos de los vecinos de esta área protegida, era un tanto difícil comprender por qué se sembraban tantos árboles en los potreros, en especial en aquellos que por sus características (según las versiones de los pobladores) podrían ser utilizados para actividades agropecuarias. Además de lo económico, muchos habitantes consideran que el uso en la siembra de árboles puede traer consecuencias para la salud y seguridad local. 



\section{Conclusiones}

En esta investigación se analizaron las tensiones que tienen lugar en Guasca por cuenta de la constitución de la RBE. Las condiciones históricas de usos de los recursos naturales, arraigadas en ciertas prácticas cotidianas y económicas, contrastan con los discursos de la biodiversidad, la restauración ecológica y el ambientalismo. En Pueblo Viejo se presentan tensiones entre los funcionarios de la FNC y la población por la manera de entender los usos de la tierra que se encuentran al interior y exterior de la RBE. Los habitantes locales conciben que el aprovechamiento de este recurso debe estar acorde a su vocación. Esto quiere decir, sembrar los árboles en zonas secas o en las cabeceras de los potreros en donde no crezca pasto o se necesite contrarrestar la erosión.

Por su parte, la FNC promueve un discurso que propende por los usos sustentables de la tierra, el agua y el bosque, así como su restauración ecológica. Incluso, pretenden extender este tipo de uso a la población de la región, es decir a otros propietarios, a través de la pedagogía y la educación ambiental. Sin embargo, estas pretensiones de la FNC parten del aprendizaje a través del ejemplo, más que de la interacción, pues hasta el momento han sido pocas las formas de persuasión de la población local a través de reuniones o 
talleres que fomenten usos conservacionistas de los recursos ambientales.

Las formas de entendimiento de la vocación de los recursos naturales tienen que ver con unas lógicas culturales y unas representaciones de las maneras adecuadas de su aprovechamiento. Por ejemplo, los conocimientos sobre cómo atraer el agua a partir de la siembra de ciertas especies vegetales en determinados sitios de los potreros que no interfieran con las actividades productivas hacen parte del acervo que entra en tensión con los procesos de restauración ecológica desarrollados por la FNC en la RBE. No solo es, entonces, una tensión por cuenta de las dificultades económicas que acarrea la siembra total de los potreros de la RBE (lo cual es un asunto que no sucederá, según el jefe de la reserva), se trata además de una tensión sobre los significados atribuidos a los recursos naturales.

Las dificultades económicas de la siembra de árboles en los potreros al interior de la RBE utilizados para el pastoreo en una comunidad campesina mayoritariamente dedicada a la ganadería lechera tienen, obviamente, un peso dentro de la tensión. Esto se hizo evidente en el trabajo de campo en donde se pudo apreciar que los pobladores locales veían con preocupación la restauración ecológica a nivel de las dificultades económicas. Sin embargo, es necesario no perder de vista en el análisis cómo las formas de uso y entendimiento de la vocación del suelo están atravesadas por formaciones discursivas históricas y culturales que se encuentran en constante debate y definición. Allí yacen, además, las consideraciones locales sobre los peligros que acarrea la extensión de la montaña 
para la seguridad de los pobladores, que tienen que ver con representaciones particulares de la naturaleza y los sujetos peligrosos (guerrilla, fieras y ladrones) asociados a esta.

Estas tensiones de tipo cultural se expresan en las formas de entendimiento de la naturaleza y la finca como unidades de territorio en oposición o articulación al bosque, el monte o la montaña. Además, se oponen los significados de naturaleza salvaje y peligrosa con los de la biodiversidad y la conservación ambiental. Si bien en esta investigación la pregunta central no se preocupó por indagar a mayor profundidad en las representaciones de la naturaleza entre los campesinos, presentó algunos elementos preliminares útiles para criticar las ideas de estos sujetos como desligados del territorio y carentes de cultura, los cuales se dejan abiertos para su indagación y discusión en ulteriores trabajos.

Desde las consideraciones locales, la naturaleza (montaña) es una entidad salvaje y peligrosa que alberga seres humanos y no humanos que pueden causar daño, por lo que es necesario mantenerla a raya. En otras ocasiones, la naturaleza (monte) es un valor agregado a la finca y no se opone a esta unidad territorial, pues hace parte integral de esta a nivel estético y económico.

Lo anterior conduce a plantear que la naturaleza es múltiplemente conceptualizada, es decir, no es un todo homogéneo y coherente, sino que se encuentra en constante producción y significación. Tal condición de la naturaleza significa que las tensiones en Pueblo Viejo no solo tienen tintes económicos, sino que se dan por la definición del territorio y la naturaleza. Situando el debate en relación con otros casos en 
donde, a diferencia de Guasca, se ponen en escena tensiones entre conservación y etnicidad, que se presentaron en este trabajo (Bocarejo, 2011; Durán, 2009; Li, 2002; Luque y Valenzuela, 2001; Ojeda, 2012; Ulloa, 2004), se propone que las ideas sobre los campesinos que desconocen sus relaciones y simbolizaciones de la naturaleza están atravesadas por políticas de la diferencia que marcan las etnicidades (como las de los indígenas) a partir del desconocimiento de otras "diferencias culturales" (las de los campesinos).

A la luz del caso de Guasca, a partir de estas articulaciones entre políticas de la alteridad y políticas ambientales, saltan a la vista las desventajas de los grupos campesinos para ser partícipes del manejo de los recursos del entorno y ser respetadas y reconocidas sus formas de relación y simbolización de la naturaleza. Al respecto, surgen algunos interrogantes a partir de la falta de reconocimiento de los derechos territoriales y culturales de los campesinos: ¿qué hay de la etnicidad campesina?, ¿ son los campesinos sujetos rurales cuya etnicidad no ha sido reconocida?, ¿qué tan diferentes son campesinos e indígenas en sus formas de pensar la naturaleza y conocer su funcionamiento?

Las tensiones económicas sobre el trabajo y la economía local presentadas en esta investigación trascienden a Guasca, pues se enmarcan en la situación general del campo en Colombia e, incluso, en Latinoamérica. Acorde con el Informe nacional de desarrollo bumano rural de 2011, del Programa de las Naciones Unidas para el Desarrollo (PNUD), las áreas rurales del país enfrentan altos índices de pobreza por cuenta de la alta concentración de la tierra y la falta de 
empleos dingos en cuanto a contratos y salarios. El problema radica en la falta de políticas agrarias serias que fomenten el desarrollo y la equidad en el campo. Esta situación se presenta en Pueblo Viejo, en especial por la ausencia de contratos laborales estables con condiciones salariales adecuadas para la superación de la pobreza. Allí, las grandes fincas lecheras que concentran numerosas hectáreas de tierra no están brindando trabajo estable para la población.

Por su parte, otro tipo de propiedades extensas e históricamente dedicadas a actividades económicas que han suplido la demanda laboral se encuentran actualmente en manos de la FNC, la cual ha abierto la puerta a buena parte de los pobladores locales para el desarrollo de actividades pecuarias, bajo la modalidad de concesionarios de sus predios. Los pequeños ganaderos encuentran allí la posibilidad de comprar los pastos para el pastoreo de su ganado. En este aspecto, la FNC ha suplido las expectativas de los pobladores locales. No obstante, en cuanto al trabajo directo ofrecido por la FNC, existen una serie de reparos por su frecuencia y cantidad. Los pobladores esperan mayores fuentes de trabajo y con mayor regularidad en la RBE, pero el empleo que se ofrece es por días, por lo que la remuneración no alcanza para la subsistencia. Esto quiere decir que las formas directas de trabajo ofrecidas en la RBE no son una alternativa laboral para la población local.

En el contexto de pobreza rural en el país y de concertación de la tierra, los pequeños propietarios y campesinos sin tierra se ven abocados a arrendar predios, comprar pastaje o proletarizarse. En Guasca, se están dando dos de estas 
dinámicas. La población local está comprando pastos de los predios de propiedad de la FNC. Esta situación se da debido a que los pequeños fundos no alcanzan para suplir las necesidades de producción que requiere la ganadería lechera como medio de subsistencia.

Por otra parte, los habitantes locales han sido empleados en algunas labores en la FNC como guías turísticos, cocineros, obreros y en servicios generales. Además, una buena parte de la población ha emigrado por fuera de la vereda para trabajar en fábricas, empleo doméstico y servicios generales, es decir, se ha proletarizado y urbanizado (Echeverri y Ribero, 2002).

En cuanto a la FNC, las labores no suplen la demanda de trabajo por cuenta de la escasez e intermitencia de su frecuencia y el hecho de que los trabajos de guías, cocina y servicios generales son realizados por las mismas personas (o por personas externas a la vereda), lo que disminuye el número de ofertas de trabajo que generan. Adicionalmente, los obreros y maestros de obra local son empleados para trabajar por temporadas en donde sea necesario realizar labores de mantenimiento de las instalaciones de la FNC o alguna construcción.

Las percepciones locales sobre el trabajo versan sobre la necesidad de mayores ofertas labores en la vereda, pues ven como una dificultad el desplazamiento por fuera del sector para buscar trabajo, en especial para las mujeres. Esto tiene que ver, asimismo, con una añoranza por la mina de caliza que era la fuente de muchos trabajos cercanos a las viviendas de los trabajadores y que les proporcionaba 
óptimas condiciones a nivel de salarios, condiciones laborales y prestaciones sociales.

Esta investigación indagó por las tensiones que surgen en las formas de empleo ofrecidas por la FNC y sus implicaciones para la economía local. Por un lado, las concesiones para la venta de pastos en la RBE han sido una forma de democratización del acceso a la tierra, en tanto estos predios estuvieron bajo explotación directa de sus dueños y posteriormente de un arrendatario, quien no subarrendaba. La población era empleada en las labores que realizaban los propietarios o el arrendatario como mano de obra asalariada. Al constituirse la RBE, la población empezó a tener mayor acceso a estos predios para su usufructo particular e independiente en actividades ganaderas. Allí se encuentra el papel clave de las concesiones para la economía local. Esta área protegida, al permitirles a gran parte de la población local el desarrollo de las actividades económicas en ganadería que les brinda subsistencia, ha ayudado a fortalecer buena parte de la economía local, a la vez que genera recursos monetarios para el sostenimiento de la RBE expresados en los pagos que hacen los concesionarios por las pastadas.

En consecuencia, la FNC se ha articulado con algunas formas económicas locales. Su lógica de venta de pastos se basa en las formas locales de compra de este recurso natural. Sin embargo, existen concesionarios que les gustaría pasar a ser arrendatarios de la FNC porque esto les permitiría disponer de manera más autónoma y prolongada de los predios al interior de la RBE. Este reparo implica que el acceso a los recursos naturales por medio de las concesiones tiene lugar, 
pero bajo unas condiciones particulares de aprovechamiento que impiden la efectuación de "mejoras" o la intervención de los terrenos.

Es decir, el régimen de propiedad y la capacidad de decisión sobre estas tierras no se trasfieren ni siquiera de forma momentánea, como lo supondría un contrato de arrendamiento. Los concesionarios usan lo que les corresponde (agua y pastos), pero carecen de poder de decisión y acción sobre estas tierras más allá de su actividad económica. Por esta razón, la concesión es la forma aplicada en las áreas protegidas porque permite mayor control sobre los usos de los recursos naturales en aras de una presumible concordancia con los objetivos de la conservación.

El manejo ambiental descentrado de la acción estatal por cuenta del neoliberalismo, para el caso de Guasca, se torna complejo. Las concesiones, como se ha sostenido en esta investigación, no implican como tal una gobernanza o un manejo participativo sobre los recursos ambientales. Aquí es necesaria la distinción entre acceso a los recursos y manejo. Si bien el acceso implica un uso, esto no quiere decir un manejo efectivo que implique la toma de decisiones sobre el aprovechamiento de estos recursos naturales. La FNC es la que determina estos usos, eso sí, dentro de los parámetros que supone un aprovechamiento ganadero propio de la zona.

Obviamente existe un margen de negociación en el que las poblaciones locales exigen unos mínimos necesarios de aprovechamiento relacionadas con su actividad ganadera. Sin embargo, el grueso de las decisiones sobre el uso de 
los recursos naturales de la RBE es una decisión que le ha competido solamente a la FNC. Por lo pronto, las concesiones han servido como sustento económico para la población local, pero no como una forma de descentralización y democratización del manejo ambiental y de participación efectiva de la población local en la toma decisiones sobre la RBE.

¿Puede el trabajo en las áreas protegidas fomentar la participación en su manejo? No deja de ser cuestionable hasta qué punto una interacción de patrón-empleado (con las relaciones de poder que conlleva) pueda fomentar una participación efectiva. Es decir, no se puede asumir que un modelo de descentralización del manejo ambiental signifique un verdadero empoderamiento de la población local, mucho menos si está basado en el trabajo.

Por otra parte, el proponer que las poblaciones locales deban dialogar con un sujeto externo para poder manejar los recursos naturales y el entorno que han habitado por generaciones es sumamente complicado si se tiene en cuenta lo que ello acarrearía en cuanto a su autonomía y derechos territoriales. Además, el hecho de que algunos trabajen en la RBE y otros no puede socavar la participación de algunos pobladores, toda vez que se generen pugnas internas en la población local por el acceso a los beneficios laborales, participativos y económicos en el área protegida. El modelo neoliberal de gobernanza ambiental, cuya base es la descentralización de las funciones de manejo ambiental estatal para delegarlas en actores privados, no puede desligarse de las relaciones de poder y la desigualdad entre las partes, así como sus intereses particulares y motivaciones. 
En el caso de la RBE, pese a la existencia de unos pocos puestos de trabajo por días y un número significativo de concesionarios, no se han fomentado formas de gobernanza en las que la población sea partícipe en la toma de decisiones y el manejo ambiental del área protegida de forma efectiva. En este texto se argumenta que son los trabajos y las concesiones, acompañados claro está de procesos de concertación, los que pueden llegar a permitir a las personas manejar los recursos naturales y recibir un sustento económico.

El trabajo y las concesiones son formas de actuar concretas que, orientadas más allá de la relación propietario de la tierra-comprador de pastos o empleado-jefe, pueden significar maneras efectivas de empoderamiento en la práctica del manejo de los recursos del ambiente. Esto tendría que ver con que los concesionarios y empleados contaran con voz y voto en la toma de decisiones del área protegida y que pudieran manejar los recursos naturales de manera más autónoma a través de procesos de concertación con los administradores del área, pues, de lo contrario, solo seguirían siendo antiguos trabajadores mineros (o hijos de ellos) hoy convertidos en concesionarios y mano de obra del ecoturismo.

Como parte de la antropología ambiental, en Colombia está surgiendo todo un campo de estudio de los procesos políticos de intervención y lucha entre los discursos ambientales globales y los modelos locales de naturaleza y territorio (Ojeda, 2012; Bocarejo, 2011; Del Cairo, 2012). Los intereses de estudio de la antropología por las formas de apropiación humana del entorno están ahora dando un giro hacia propuestas que enfatizan en las luchas político-ambientales 
de carácter simbólico y económico, en relación con procesos globales. Estos nuevos enfoques estan siendo desarrollados por todo un equipo de trabajo en el Centro de estudios en ecología política (CEEP)

Dentro de estas pretensiones, y en el marco de este libro, están aún por analizar, entre otros aspectos, cómo las formas de simbolización que los campesinos elaboran de la naturaleza están en lucha con el ambientalismo y cuáles son los “modelos campesinos" de naturaleza. 



\section{Bibliografía}

Agrawal, A. (2001). Common property institutions and sustainable governance of resources. World Development, 29 (10), 1649-1672.

Agrawal, A. y Lemos, M. (2007). A greener revolution in the making? Environmental Governance in the $21^{\text {st }}$ Century. Environment, 49(5), 37-46.

Amend, S. y Amend T. (Eds). (1992). ¿Espacios sin habitantes? Parques nacionales de América del Sur. Caracas: Editorial Nueva sociedad-Unión Internacional para la Conservación de la Naturaleza (UICN).

Biersack, A. (2011). Reimaginar la ecología política: cultura/poder/historia/naturaleza. En L. Montenegro(Ed.), Cultura y naturaleza: aproximaciones a propósito del bicentenario de la independencia de Colombia (pp. 135-192). Bogotá: Centro de Investigación y Desarrollo Científico, Jardín Botánico de Bogotá José Celestino Mutis.

Bravo, E. (2012). Una crítica a las propuestas de conservación de la biodiversidad a través de mecanismos de mercado. Biodiversidad, sustento y culturas, (72), 3-6.

Brenner, L. y Job, H. (2006). Actor-oriented management of protected areas and ecotourism in Mexico. Journal of Latin American Geography, 5(2), 7-27. 
Bocarejo, D. (2011). Dos paradojas del multiculturalismo colombiano: la espacialización de la diferencia indígena y su aislamiento político. Revista Colombiana de Antropología, 47(2), 97-121.

Bocarejo, D. y Restrepo, E. (2011). Introducción. Revista Colombiana de Antropología, 47(2), pp. 7-13.

Burbano, A. (2005). Género y ecoturismo. En E. Escobar, P. Escobar, A. Pazmiño y A. Ulloa (Eds.), Las mujeres indígenas en los escenarios de la biodiversidad (pp. 83-89). Bogotá: Unión Internacional para la Conservación de la Naturaleza (UICN), Fundación Natura Colombia e Instituto Colombiano de Antropología e Historia (ICANH).

Büscher, B. y Dietz, T. (2005). Conjunctions of governance: The state and the conservation-development nexus in Southern Africa. The Journal of Transdisciplinary Environmental Studies, 4(2), 1-15.

Cámara de Comercio de Bogotá. (2012). Certificado de existencia y representación legal de la compañia explotadora de cal. Bogotá: Autor.

Camargo, P. y Moreno, N. (2008). Estado actual de la avifauna en la Reserva Biológica encenillo (RBE) Guasca-Cundinamarca (Tesis de grado). Universidad Innca de Colombia, Bogotá.

Campos, C. y Ulloa, A. (Eds.). (2003). Fauna socializada: tendencia en el manejo de la fauna en América Latina. Bogotá: Fundación Natura Colombia, MacArthur Foundation e Instituto Colombiano de Antropología e Historia (ICANH). 
Cano, I. (2005). Prácticas productivas, lógicas culturales y transformaciones en la alta montaña. Cundinamarca, 19001980. Revista Colombiana de Antropología, 41, 43-73.

Castaño Uribe, C. (1992). Ocupación humana en parques nacionales de Colombia: política y perspectivas. En S. Amend y T. Amend (Eds.), ¿Espacios sin habitantes?: parques nacionales de América del Sur (pp. 177-191). Caracas: Editorial Nueva Sociedad, Unión Internacional para la Conservación de la Naturaleza (UICN).

Cavalcanti, J. y da Mota, D. (2003). Agricultura y trabajadores rurales en Brasil. En M. Bendini, J. Cavalcanti, M. Murmis y P. Tsakoumagkos (Comps.), El campo en la sociología actual: una perspectiva latinoamericana (pp. 237-259). Buenos Aires: La Colmena.

Cepek, M. (2011). Foucault in the forest: Questioning environmentality in Amazonia. American Ethnologist, 38(3), 501-515.

Cuche, D. (2007). La noción de cultura en las ciencias sociales. Buenos Aires: Nueva Visión.

Del Cairo, C. (1998). Tucanos y colonos del Guaviare: estrategias para significar el territorio. Revista Colombiana de Antropología, 34, 66-91.

Del Cairo, J. (2010). Una experiencia comunitaria y participativa de conservación y ordenamiento socioambiental en la Serranía de La Lindosa. En G. Palacio (Ed.), Ecología política de la Amazonia. Las profusas y difusas redes de la gobernanza (pp. 482- 518). Bogotá: Universidad Nacional de Colombia, Instituto Latinoamericano para una Sociedad y un Derecho Alternativos (ILSA) y Ecofondo. 
Del Cairo, C. (2012). Environmentalizing indigeneity: A comparative ethnography on multiculturalism, ethnic hierarchies and political ecology in the Colombian Amazon (Tesis doctoral). The University of Arizona, Tucson.

Del Cairo, C. (21-23 de octubre de 2013). Aportes antropológicos para explorar la articulación entre etnoecologias, territorios y ruralidades. IV Congreso Colombiano de Etnobiología, Bogotá.

Descola, P. (2001). Construyendo naturalezas. Ecología simbólica y práctica social. En P. Descola y G. Palsson (Eds.), Naturaleza y sociedad. Perspectivas antropológicas (pp. 101-123). México: Siglo XXI.

Descola, P. (2002). La antropología y la cuestión de la naturaleza. En G. Palacio y A. Ulloa (Eds.). Repensando la naturale$z a$, encuentros y desencuentros disciplinarios en torno a lo ambiental (pp. 155-171). Bogotá: Universidad Nacional de Colombia-Sede Leticia, Imani, Instituto Colombiano de Antropología e Historia (ICANH), Colciencias.

Dewalt, K., Dewalt, B. y Coral, W. (1998). Participant observation. En B. Russell (Ed.), Handbook of methods in cultural anthropology (pp. 259-299). Walnut Creek: AltaMira Press.

Durán, A. (2009). Gobernanza en los parques nacionales naturales colombianos: reflexiones a partir del caso de la comunidad Orika y su participación en la conservación del Parque Nacional Natural Corales del Rosario y San Bernardo. Revista de Estudios Sociales, 32, 60-73. 
Dussán, A. (1953). La repartición de alimentos en una sociedad de transición. Revista Colombiana de Antropología, 1, 259-278.

Echeverri, R. y Ribero, M. (2002). Nueva ruralidad. Visión del territorio en América Latina y el Caribe. Bogotá: Centro interdisciplinario de Estudios sobre Desarrollo (Cider), Instituto Interamericano de Cooperación para la Agricultura (IICA), Corporación Latinoamericana Misión Rural. Escobar, A. (2005). Más allá del Tercer Mundo. Globalización $y$ diferencia. Bogotá: Instituto Colombiano de Antropología e Historia (ICANH), Universidad del Cauca.

Escobar, A. (2010). Ecologías politicas postconstructivistas. Recuperado de http://www.unc.edu/ aescobar/text/esp/ escobar.2010.EcologiasPoliticasPostconstructivistas.pdf Fajardo, D. y Sepúlveda, M. (1995). Las zonas de reserva campesina: ¿un instrumento para el desarrollo humano sostenible. Revista Nacional de Agricultura, (912-913), 103-129.

Fals Borda, O. (1961). Campesinos de los Andes: un estudio sociológico de Saucío. Bogotá: Editorial Iqueima.

Flores, S. y de Grammont, H. (2003). Los efectos de las migraciones rurales internas en la conformación de los grupos domésticos. M. Bendini, J. Cavalcanti, M. Murmis y P. Tsakoumagkos (Comps.), El campo en la sociología actual: una perspectiva latinoamericana. (pp. 213-236). Buenos Aires: La Colmena.

Franky, C. y Mahecha, D. (2010). Objetivizar para gobernar: comunidades indígenas, censos poblacionales, control territorial y políticas públicas en la amazonia colombiana. En G. Palacio (Ed.), Ecología política de la Amazonia. Las 
profusas y difusas redes de la gobernanza (pp. 122-144). Bogotá: Universidad Nacional de Colombia, Instituto Latinoamericano para una Sociedad y un Derecho Alternativos (ILSA) y Ecofondo.

Fundación Humedales. (s. f.). Nuestro equipo. Recuperado de http://fundacionhumedales.forexmentorlat.com/index. $\mathrm{php} / \mathrm{cliente} /$ interna/14

Fundación Natura Colombia. (s. f.). Format for pre-proposals Small Grants for the Purchase of Nature (SPN) of the IUCN National Committee of the Netherlands. Corredor de Encenillo, propuesta de ampliación para la protección de los últimos bosques andinos cercanos a Bogotá-Colombia. Formato de aplicación. Documento inédito.

Fundación Natura Colombia. (2005). Reunión mayo 19 del 2005-06-09. Acta de reunión. Documento inédito.

Fundación Natura Colombia. (2008a). Reserva biológica del Encenillo. Recuperado de http://www.natura.org.co/ general/reserva-biologica-del-encenillo.html

Fundación Natura Colombia. (2008b). ¿Qué diferencia existe entre la reforestación y la restauración ecológica? Recuperado de http://www.natura.org.co/campana-regalaun-arbol/campana-regala-un-arbol.html

González, D. y Múnera, J. (1998). Las zonas de reserva campesina: El Pato, una propuesta de desarrollo integral de la región campesina. En M. Cárdenas, C. Mesa y C. Riascos (Comps.), Planificación ambiental y ordenamiento territorial. Enfoques, conceptos y experiencias (pp. 271-310). Bogotá: Friedrich Ebert Stiftung en Colombia (Fescol), Cerec y Departamento Nacional de Planeación (DNP). 
Gonzáles, C. (2014). "El que tiene tierra que la atienda”. Tensiones en torno a la propiedad y el trabajo en el Parque Tayrona. (Tesis de grado). Universidad del Rosario, Bogotá.

Graham, J. y Gibson, K. (2002). Intervenciones posestructurales. Revista Colombiana de Antropología, 38, 261-286 Guhl, E. (1953). El aspecto económico social del cultivo de café en Antioquia. Revista Colombiana de Antropología, 1, 197-257.

Harris, M. (1998). Vacas, cerdos, guerras y brujas: los enigmas de la cultura. Madrid: Alianza Editorial.

Hernández, J., Castro, R., Aguilar, G. y Domínguez, M. L. (2005). Pobreza rural y medio ambiente. Experiencias en cuatro comunidades de la selva seca de Oaxaca, México. Cuadernos de Desarrollo Rural, (55), 71-96.

Lemos, M. y Agrawal, A. (2006). Environmental governance. Annual Review of Environmental Resources, (31), 297325.

Li, T. (2002). Engaging simplifications: Community-based resource management, market processes and state agendas in upland southeast Asia. World Development, 30(2), 265-283.

Londoño, B. (2008). Las organizaciones no gubernamentales ambientales colombianas y su ejercicio de las herramientas de participación institucionalizada. En M. Rodríguez (Ed.), Gobernabilidad, instituciones y medio ambiente en Colombia (pp. 523-549). Bogotá: Editorial Gente Nueva. Luque, A. y Valenzuela, S. (2001). La participación de culturas indígenas en la protección y conservación del piedemonte amazónico colombiano. En Unidad Administrativa 
Especial-Sistema de Parques Nacionales Naturales, Parques con la gente. Política de participación social en la conservación. Avance 1998-2000. (pp. 35-43). Bogotá: Autor. Meertens, D. (2000). Ensayos sobre tierra, violencia y género: hombres y mujeres en la historia rural de Colombia, 19301990. Bogotá: Universidad Nacional de Colombia.

Ministerio de Ambiente, Vivienda y Desarrollo Territorial. (1 de julio de 2010). Decreto 2372, "Por el cual se reglamenta el Decreto-ley 2811 de 1974, la Ley 99 de 1993, la Ley 165 de 1994 y el Decreto-ley 216 de 2003, en relación con el Sistema Nacional de Áreas Protegidas, las categorías de manejo que lo conforman y se dictan otras disposiciones”. Diario oficial, pp. 21-26.

Monterroso, I. (2006). Comunidades locales en áreas protegidas: reflexiones sobre las políticas de conservación en la reserva de biosfera maya. En H. Alimonda(Comp.), Lostormentos de la materia. Aportes para una ecología politica latinoamericana (pp. 239-274). Buenos Aires: Clacso.

Mora, Y. (1974). Notas para el estudio de la alimentación en Ráquira. Revista Colombiana de Antropología, 17, 66-74. Morales, J. (1966). El fondo de la renta en una comunidad tabacalera de Santander. Revista Colombiana de Antropología, 14, 278-285.

Moreno, C. (2001). Las peleas entre el diablo y la Virgen: permanencias culturales y memoria histórica entre los campesinos de Boyacá. Revista Colombiana de Antropología, 37, 42-59.

Moscoso, A. (1992). Parque nacional Amboró y la presión colonizadora. En S. Amend y T. Amend (Eds.), ¿Espacios 
sin habitantes?: Parques nacionales de América del Sur (pp. 81-88). Caracas: Editorial Nueva Sociedad-Unión Internacional para la Conservación de la Naturaleza (UICN). Municipio de Guasca. (2012). Plan de desarrollo del municipio de Guasca 2012-2015. Colombia: Autor.

Myers, E. y Uribelarrea, D. (1992). Los Alerces: protección de los recursos naturales y el uso social. En S. Amend y T. Amend (Eds.), ¿Espacios sin habitantes?: Parques nacionales de América del Sur (pp. 27-36). Caracas: Editorial nueva sociedad-Unión Internacional para la Conservación de la Naturaleza (UICN).

Notaría del Circuito de Guatavita. Escrituras públicas número 59 de 1943; 51, 104, 105 y 157 de 1945; 14, 58, 59, 281, 285 y 286 de 1946; 17 y 171 de 1947; 55 y 163 de 1948; 167 de 1949; 226 de 1958; 335 de 1966; 330 de 1970.

O’Connor, J. (2003). ¿Es posible el capitalismo sostenible? En H. Alimonda (Comp.), Ecología política, naturaleza sociedad y utopia (pp. 27-52). Buenos Aires: Clacso.

Ojeda, D. (2012). Producing paradise: The violent geographies of tourism in Colombia (Tesis doctoral). Clark University, Worcester, EE. UU.

Orozco, E., Guerrero, A., Vargas, E., Velázquez, D. y Colín, J. (2008). Supervivencia campesina y conservación de la naturaleza: Santuario del Cerro Pelón(Reserva de la Biosfera Mariposa Monarca), El Capulín, México. Cuadernos de Desarrollo Rural, 5(61), 131-168.

Osidala, N., Romero, R. y Corvalán, C. (1992). Parque nacional Lanín: manejo de los recursos naturales con pobladores locales. En S. Amend y T. Amend (Eds.). ¿Espacios 
sin habitantes?: Parques nacionales de América del Sur (pp. 37-49). Caracas: Editorial Nueva Sociedad-Unión Internacional para la Conservación de la Naturaleza(UICN). Peluso, N. (2005). Seeing property in land use: Local territorializations in West Kalimantan, Indonesia. Danish Journal of Geography, 105(1), 1-15.

Pinilla, M. C. (2004). Uso del paisaje en el sector sur del Parque Natural Nacional Amacayacu (Amazonas-Colombia). Cuadernos de Desarrollo Rural, 53, 133-156.

Plumwood, V. (1993). Dualism: The logic of colonization. En Feminism and the mastery of nature (pp.41-68). London, New York: Routledge.

Programa de las Naciones Unidas para el Desarrollo en Colombia (PNUD). (2011). Colombia rural. Razones para la esperanza. Informe nacional de desarrollo bumano 2011. Resumen ejecutivo. Bogotá: PNUD. Recuperado de http://pnudcolombia.org/indh2011/

Redfield, R. (1956). Peasant society and culture: an anthropological approach to civilization. Chicago: The University of Chicago Press.

Reichel-Dolmatoff, G. (1977). Cosmología como análisis ecológico: una perspectiva desde la selva pluvial. En G. ReichelDolmatoff y A. Dussán (Eds.), Estudios antropológicos (pp.355-375). Bogotá: Instituto Colombiano de Cultura. Reyes, S. y López, I. (1992). Parque Nacional Sierra Nevada: cooperación con los habitantes tradicionales. En S. Amend y T. Amend (Eds.), ¿Espacios sin habitantes?: parques nacionales de América del Sur (pp. 445-454). Caracas: 
Editorial Nueva Sociedad-Unión Internacional para la Conservación de la Naturaleza (UICN).

Rodríguez, E. y Sguerra, S. (2001). Identificación de actores para la concertación de un plan de manejo en el Parque Nacional Natural de Utría. En Unidad Administrativa EspecialSistema de Parques Nacionales Naturales, Parques con la gente. Política de participación social en la conservación. Avance 1998-2000 (pp. 19-26). Bogotá.

Roe, D., Nelson, F. y Sandbrook, C. (Eds.). (2009). Community management of natural resources in Africa: Impacts, experiences and future directions. Londres: International Institute for Environment and Development (IIED).

Rojas, I. (2012). Nuevas soluciones para la "comodificación" de la biodiversidad. Biodiversidad, Sustento y Culturas, 72, 7-10.

Rubio, H., Ulloa, A. y Campos, C. (2000). Manejo de la fauna de caza, una construcción a partir de lo local. Métodos $y$ herramientas. Bogotá: Orewa, Fundación Natura Colombia, Ministerio del Medio Ambiente, Organización de los Estados Americanos (OEA), Organización de Estados Iberoamericanos (OEI), Instituto Colombiano de Antropología e Historia (ICANH) y Fondo Mundial para la Naturaleza (WwF).

Ruiz, D. (2010). Las premisas de la selva: representaciones de la naturaleza en una zona de colonización campesina. En C. del Cairo y M. Chaves (Comps.), Perspectivas antropológicas de la Amazonia contemporánea (pp. 335-361). Bogotá: Instituto Colombiano de Antropología e Historia (ICANH) y Pontificia Universidad Javeriana. 
Rummenhoeller, K. (1995). Territorios indígenas y áreas naturales protegidas. En Tierra profanada, grandes proyectos en territorios indígenas de Colombia (pp. 63-90). Bogotá: Organización Nacional Indígena de Colombia (ONIC), Centro de Cooperación al Indígena (Cecoin), GhK, Unión Europea.

Sanmartín, R. (2000). La entrevista en el trabajo de campo. Revista de Antropología Social, (9), 105-126.

Shanin, T. (1979). Campesinos y sociedades campesinas. México: Fondo de Cultura Económica.

Tocancipá, J. (2005). El retorno de lo campesino: una revisión sobre los esencialismos y heterogeneidades en la antropología. Revista Colombiana de Antropología, 41, 7-41. Toledo, V. y Barrera-Bassols, N. (2008). La memoria biocultural. La importancia ecológica de las sabidurías tradicionales. Barcelona: Icaria Editorial.

Troncoso, C. (2008). Turismo, desarrollo y participación local. La experiencia de quebrada de Humahuaca Jujuy. Argentina. Aportes y Transferencias, 12(2), 110-130.

Tsing, A., Brosius, P. y Zerner, C. (2005). Introduction. En P. Brosius, A. Tsing y C. Zerner (Eds.), Communities and conservation. Histories and politics of community-based natural resource management (pp. 1-34). Walnut Creek: Altamira Press.

Ulloa, A. (2001). Transformaciones en las investigaciones antropológicas sobre naturaleza, ecología y medio ambiente. Revista Colombiana de Antropología, 37, 188-232.

Ulloa, A. (2002). De una naturaleza dual a la proliferación de sentido: la discusión antropológica en torno a la 
naturaleza, la ecología y el medio ambiente. En G. Palacio y A. Ulloa (Eds.), Repensando la naturaleza, encuentros $y$ desencuentros disciplinarios en torno a lo ambiental (pp. 139-154). Colombia: Universidad Nacional de Colombiasede Leticia, Instituto Amazónico de Investigaciones (Imani), Instituto Colombiano de Antropología e Historia (ICANH), Colciencias.

Ulloa, A. (2004). La construcción del nativo ecológico: complejidades, paradojas y dilemas de la relación entre los movimientos indígenas y el ambientalismo en Colombia. Bogotá: Instituto Colombiano de Antropología e Historia (ICANH) y Colciencias.

Ulloa, A. (2011). Concepciones de la naturaleza en la antropología actual. En L. Montenegro (Ed.), Cultura y naturaleza: aproximaciones a propósito del bicentenario de la independencia de Colombia (pp. 8-26). Bogotá: Centro de Investigación y Desarrollo Científico, Jardín Botánico de Bogotá José Celestino Mutis.

Unidad Administrativa Especial Sistema de Parques Nacionales Naturales. (2001). Parques con la gente. Politica de participación social en la conservación. Avance 1998-2000. Bogotá: Autor.

Villa, A. (1992). Parque nacional natural Amacayacu: resolución de conflictos entre las poblaciones locales y la administración. En S. Amend y T. Amend (Eds.), ¿Espacios sin habitantes?: parques nacionales de América del Sur (pp. 193-204). Caracas: Editorial Nueva Sociedad-Unión Internacional para la Conservación de la Naturaleza(UICN). 
Williams, R. (2003). Cultura. En Palabras clave: un vocabulario de la cultura y la sociedad (pp. 87-93). Buenos Aires: Nueva Visión.

Wittmayer, J. y Büscher, B. (2010). Conserving conflict? Transfrontier conservation, development discourses and local conflict between South Africa and Lesotho. Hum Ecol, 38, 763-773.

Wolf, E. (1978). Los campesinos. Barcelona: Labor.

Zárate, C. y González, A. (2001). Ordenamiento ambiental en la región de La Macarena. En Unidad Administrativa Especial-Sistema de Parques Nacionales Naturales, Parques con la gente. Política de participación social en la conservación. Avance 1998-2000 (pp. 47-54). Bogotá. 
Este libro fue compuesto en caracteres

Stempel Garamond 12 puntos, sobre papel propal de 70 gramos y encuadernado con método Hot Melt, en abril de 2015, en Bogotá, D. C., Colombia 